\title{
تحوّلات المصادر في السيّاق القرآنيّ دراسة دلاليّة
}

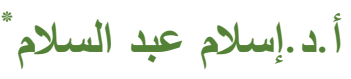

Islamm_abdelsalam@yahoo.com

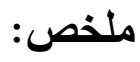

يقع هذا البحث " تحولات المصادر في السياق القرآني دراسـة دلاليـة"

ضـمن الدّراسـات النّحويـة الدّلاليـة في القرآن الكريم، وقد تـمّ اختيـار موضـوعه لأهميّته في الكثف عن النّكت الدّلاليّة في التحوّل عن المصدر الصّربح إلى

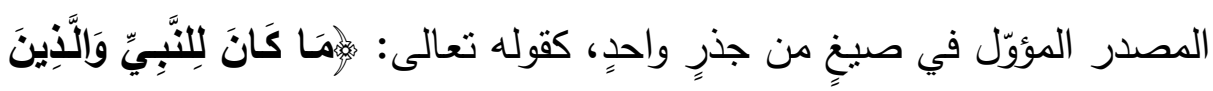

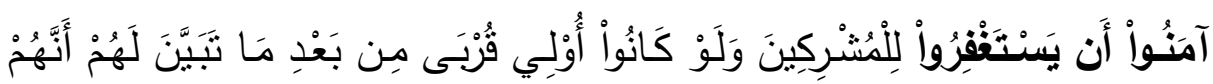

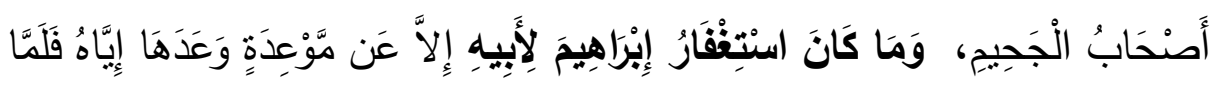

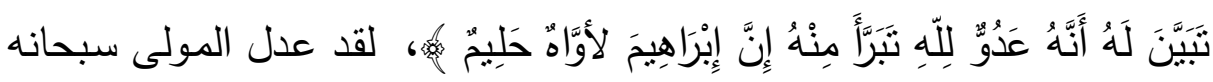
وتعالى عن المصدر الصّربح "استغفار" إلى المصدر المؤوّل " أن بستغفروا " ثمّ عاد بعدُ للتعبير بالمصدر الصّربح. واقتضت طبيعة البحث أنْ يكون في :

مقدّمة، وتمهيد، ودراسة دلاليّة: اشتملت على النماذج التى تحوّل فيها السيّاق القرآني عن المصدر الصّربح إلى المؤوّل، وخاتمة: تتاولتُ فيها أهم النتائج التي

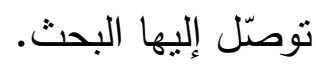

وما توفيقي إلا بالله عليه توكلتُ وإليه أنيب.

الكلمات المفتاحية: المصادر، السياق ، الدلالة

* أستاذ بقسم اللغات والترجمة بالمعهة العالي للاراسات النوعية بالهرم

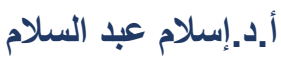

(تحولات المصادر في السياق القرآني دراسة دلالية.........) 


\begin{abstract}
This paper, "Reverse from the Explicit Verbal Noun to the Implicit Verbal Noun in the Holy Qur'an: a Semantic Study", belongs to the semantic studies category conducted on the Holy Qur'an. The topic has been chosen due to its importance in identification of the semantic implications in the reverse from the explicit Verbal Noun to the implicit Verbal Noun used in onestem forms, as shown in this Holy verse: " It is not for the Prophet and those who have believed to ask forgiveness for the polytheists, even if they were relatives, after it has become clear to them that they are companions of Hellfire. And the request of forgiveness of Abraham for his father was only because of a promise he had made to him. But when it became apparent to Abraham that his father was an enemy to Allah, he disassociated himself from him. Indeed was Abraham compassionate and patient." It is clear that Allah the Almighty has reversed the explicit Verbal Noun "the request of forgiveness" to the implicit Verbal Noun "to ask forgiveness", then He, the Almighty, uses again the explicit Verbal Noun.

Due to the type of this study, it is divided into: an introduction, a preface, a semantic study with examples of reverse from the explicit Verbal Noun to the implicit Verbal Noun in the Holy Qur'an; and a conclusion, including findings of the study.
\end{abstract}

Keywords: sources, context, connotation 
الحمد لله ربّ العـالمين والصّـلاة والسّـلام على النّبّ المصطفى، وعلى

آله وصحبه أعلام الهدى والتّى....

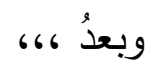

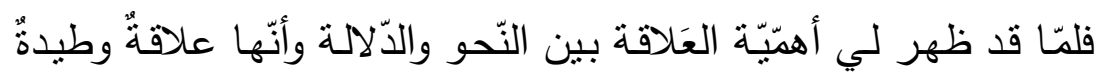

ومتماسكة في دراساتٍ لي سابقة ( اسم الفاعل بين النّوين والإضافة في القرآن الكريم دراسة دلاليّة)(1) ، و أثز السيّاق في بيان الأوجه الإعرابيّة دراسة تطبيقيّة على القرآن الكريم) (2) صرثُ أكثر ارتباطاً بالقرآن الكريم وتفاسيره، وأكثر شغفا بمسألة المعنى وقضايا النّحو المختلفة، وأخذ يتبادر إلى ذهني استفسارات دلاليّة

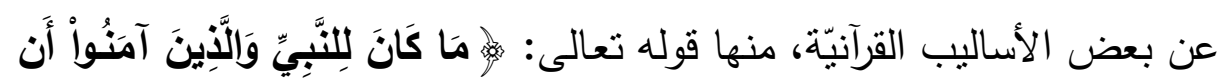

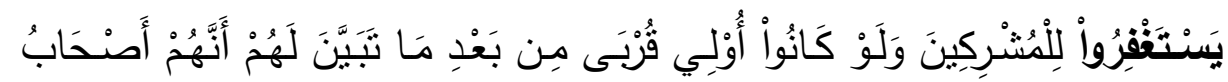

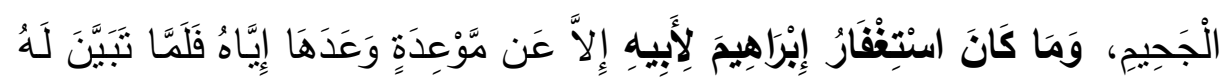

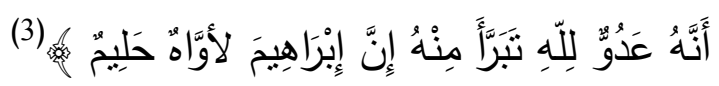
إنّ الآيتين متجاورتان (113، 114)، والبنى الصّرفيّة مختلفةُ، لقد عدل المولى سبحانه وتعالى عن المصدر الصّربح "استغفار" إلى المصدر المؤوّل " أن بستغفروا " ثمّ عاد بعدُ للتعبير بالمصدر الصّربح لاختلاف معطيات السيّياق كما سيأتي لاحقا. إنّ هذا البحث يهدف لمحاولة إظهار النكت الدلاليّة في التحوّل عن المصدر الصّريح إلى المصدر المؤوّل في صيخٍ من جذرٍ واحدٍ، وعليه فلم تكنْ كلُّ المصادر المؤوّلة هدفي في هذا البحث، فقد وقع اختياري على المصدر 
المؤول الذي تحوّل من مصدرٍ صريح حيث يثير عدول القرآن عن المصدر

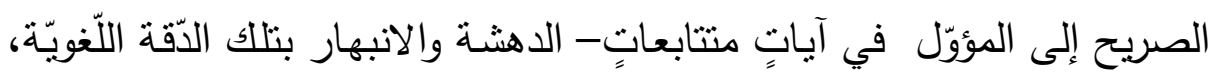

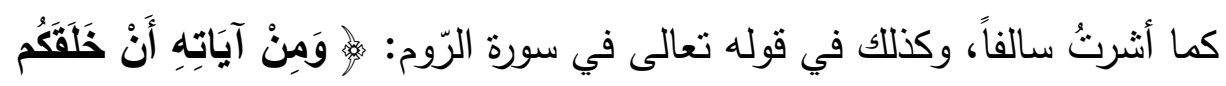

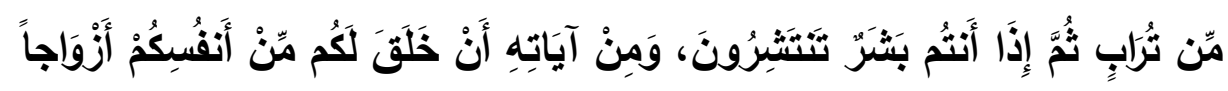

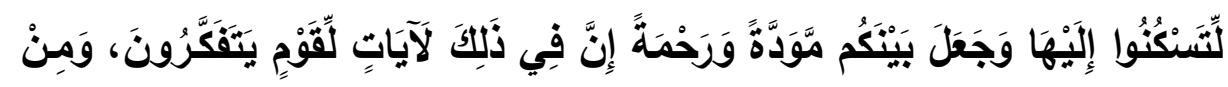

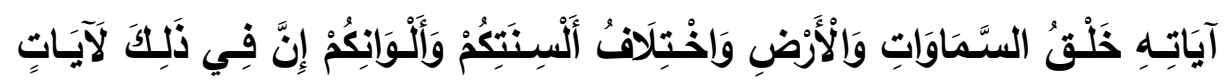

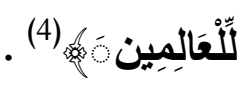
واقتضت طبيعة البحث أنْ يكون في : مقدّمة: تتاولتُ فيها هدف البحث ومنهجه وخطتّه.

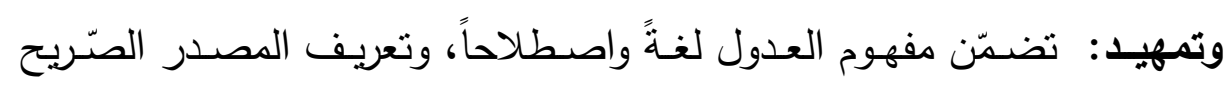

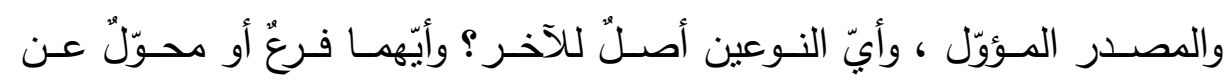
الأصل؟ للتأكيد على سبب اختبار للعنوان.

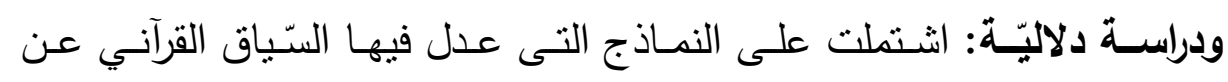

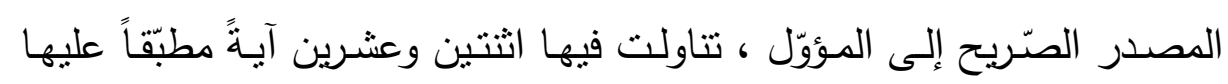
المنهج المشار إليه في هذه المقدّمة.

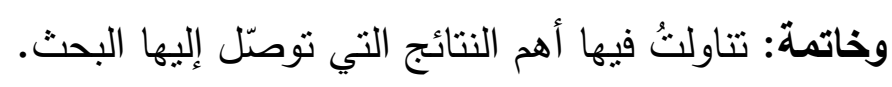

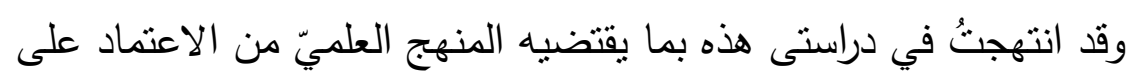

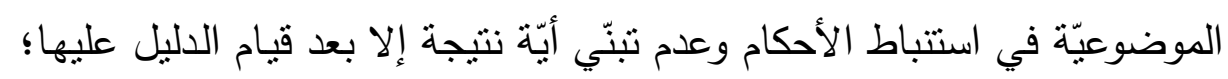

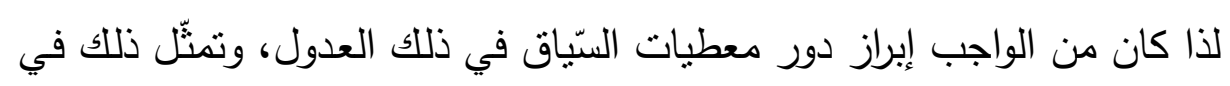


تتوع الأمتلة لإثبات أنّ ما ذهبت إليه ظاهرة تستحق الدّراسة والبحث، وليس شيئًاً عارضاً في النّصّ القرآنيّ وهو لبس بحثاً إحصـائيًاً لكلِّ نماذج المصـادر في القرآن الكريم فلقد

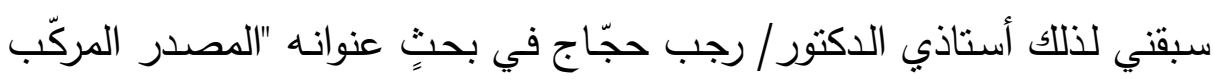

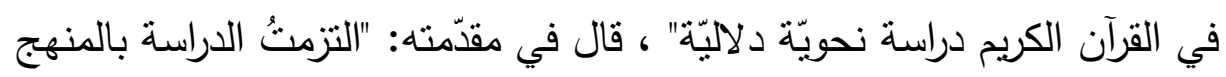
الوصفيّ التحليليّ الإحصائيّ، وقد ركّزت على المنهج الإحصائيّ لقناعتي بأنّ

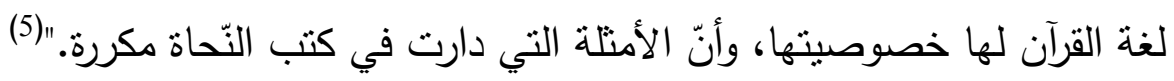

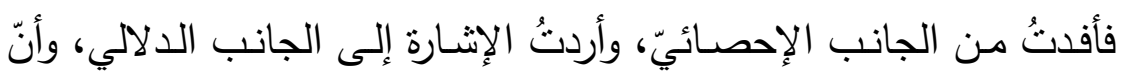

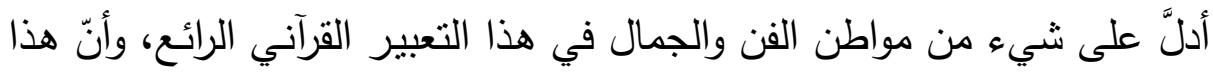

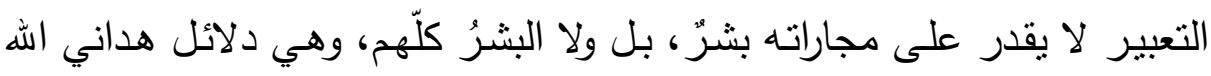

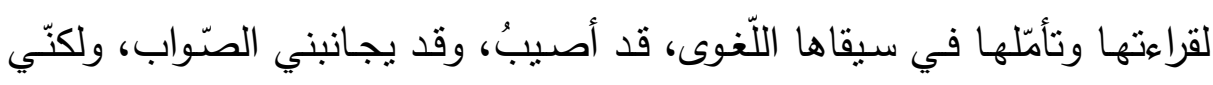

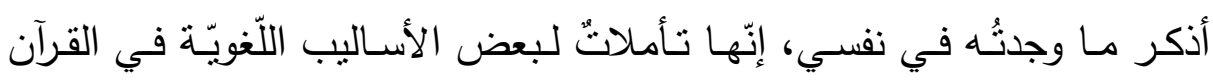

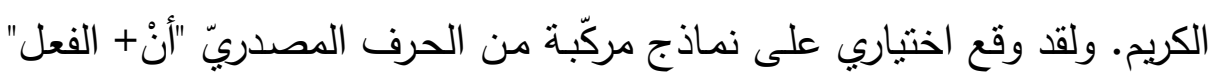

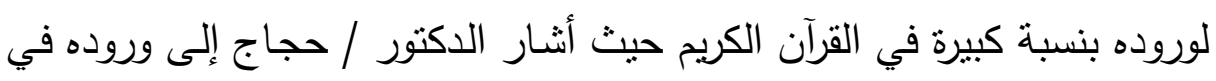
(566) خمسمائة وستّ وستين مرّة ، ثمّ اخترت المصادر الصّريحة التي تحوّل

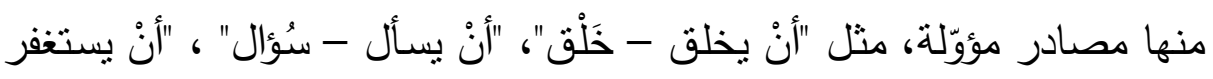
- استغْفار "؛ لبيان النّكت الدّلاليّة في العدول عن المصدر الصّريح إلى المؤوّل

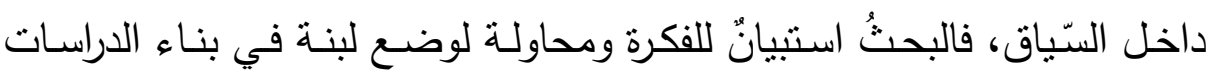
الدلاليّة السياقيّة في هذا الجانب البحثي. 
وتطلّبت حاجة البحث دراسة بعض الآيات المرتبطة بالمادة اللغويّة، جاء

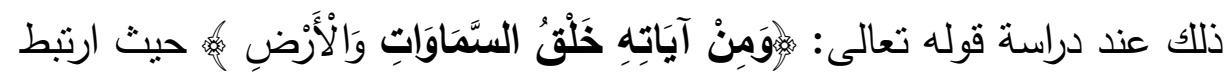

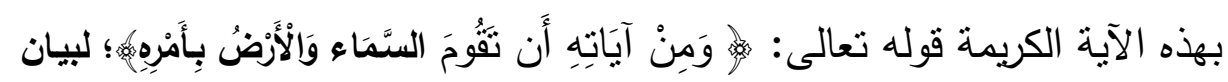

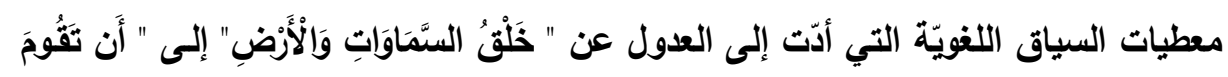

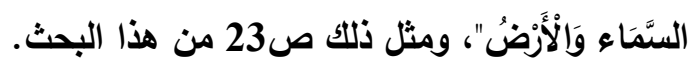

فإنْ أصبت فمن الله، وإنْ كانت الأخرى فمـن نفسي، ومـا توفيقي إلا بـالله عليه توكلتُ وإليه أنيب. 


\section{تمهيل :}

تعريف المصدر الصّريح والمصدر المؤوّل :

المصدر لغةً :

صَذْرُ كلّ شيء: أوّلُه، والمصدر هو أصل الكلمة التى تصدر عنها صوادر الأفعـال، وتفسـيره: أنّ المصـادر كانـت أوّل الكـلام، كقولـك: الـذّهاب والستّـنع والحِفْظ، وإنّما صدرت الأفعال عنها، فيقال: ذَهَبَ ذِهَاباً، وسَمِعِ سَمْعاً وسَمَاعاً،

وحَفِظ حِفظاً."(15)

المصدر الصرّيح اصطلاحاً :

الاسم الدال على مجرّد الحدث (16)، أو هو مـا يدل على معنَى مجردٍ،

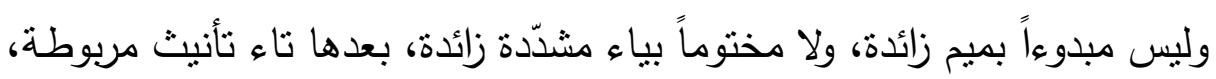

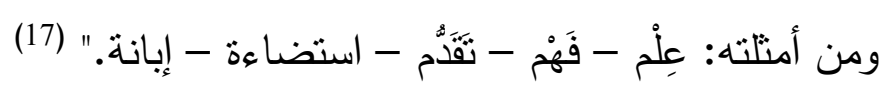

والمصدر المؤوّل : هو الذى ينسبك من الحرف المصدريّ أو الموصول الحرفيّ مع صلته، ويقال له: "المصدر المسبوك" أو "المصدر المؤوّل"(18) وهنا سؤال يطرح نفسه لماذا نلجأ في الاستعمال إلى الحرف المصدريّ وصلته ثنمّ نؤوّلههما بمصدر ، ولا نلجأ ابتداءً إلى المصدر الصّريح ؟ لَمَ نقول:مثناًَ- : يحسن أنْ تأكل، ولا نقول : يحسن أكلك ؟ للإجابة على هذا السؤال ينبغي معرفة أنّ النّحو العربي عِلْمٌ لم يهنمّ بنتبع علامات الإعراب والبناء فحسب، بل هو علمّ اهتمّ أيضاً بدلالة الجملِ والكلمات

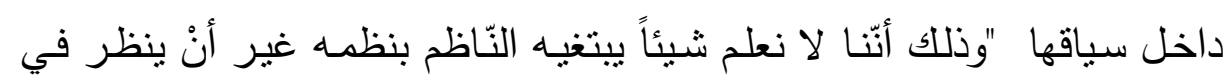
وجوه كلٍّ بابٍ وفروقه."(19) والكلام عند سيبوبه ينقسم من حيث المعنى علي 
خمسة أقسام "فنها مستقيم حسن، ومحال، ومستقيم كنب، ومستقيم قبيح، وما هو محال كذب، فأمّا المستقيم الحسن فقولك: أتنتلك أمس وسآتيك غدا، وأمّا المحال فأنْ تنقض أوّل كلامك بـآخره، فتقول: أتيتلك غدا وسـآتيك أمس، وأمّا المستقيم الكذب فقولك: حملت الجبل، وشربت ماء البحر، وأمّا المستقيم القبيح فأنْ نضع اللفظ في غير موضعه، نحو قولك:"قد زيداً رأيت، وكي زيداً يأتيك ،وأمّا المحال الكذب فأنْ تقول:سوف أثرب ماء البحر أمس."(20) اعتمد سيبوبه في النّّن السّابق على مراعاة الجمع بين حسن التركيب إلى حسن النوافق مـع المحيط الخـارجي " سياق الموقف " في مثنل "حملت الجبل، وشربت ماء البحر" فليس كلّ تركيبٍ لغويٍٍ صحيح في الجانب النحويّ يؤديّي إلى معنَى صحيح، فالموقف الخارجيّ يؤدّي إلى قبول التّركيب اللّنويّ أو رفضـه، "فالسـياق إذاً يرشـــ إلى تبـيّن المجهـل وتعيـين المحتمـل والقطـع بعـدم احتمال غير المراد وتخصيص العام المطلق وتتّوع الدلالة، فهو من القرائن الدالة على مراد المتكلم."(21) ويذكر الأستاذ عبّاس حسن أنّ الدّاعي للعدول عن المصدر الصّريح إلى المؤوّل أمورٌ هامُة تتعلّق بالمعنى أو بالضّوابط النّحويّة فمن الأولى :

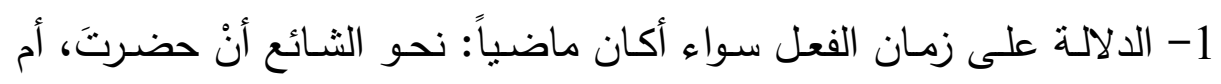
مستقبلاً: نحو: الثـائع أنْ تحضر، فلو قلنا من أوّل الأمر : الثـائع حضورك، لم ندر زمن الحضور أمضى أم لم يَمْضِ ؟ لأنّ المصدر الصّرِيح لا يدل بنفسه

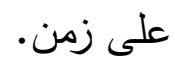


2- الدلالة على أنّ الحكم مقصورٌ على المعنى المجرّد للفعل، من غير نظر

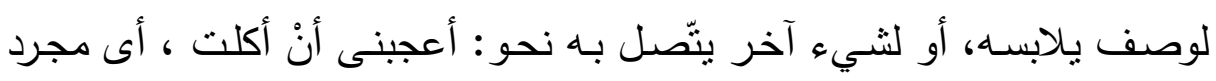

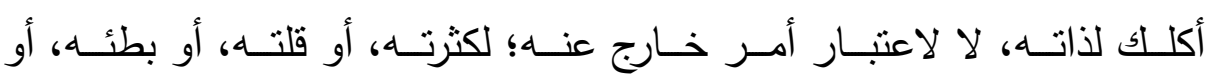

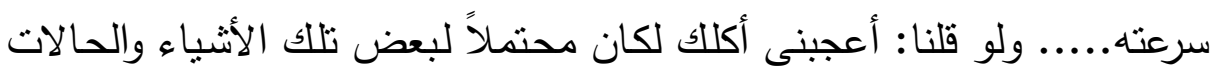
كطريقة الأكل، أو نوع المأكول.

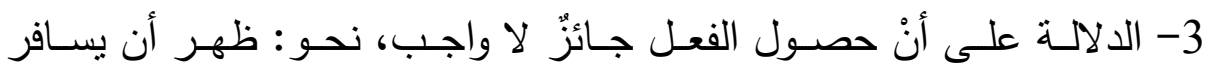

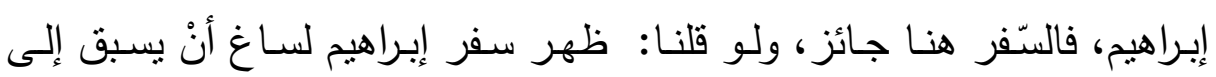
بعض الأذهان أنّ هذا الأمر واجبٌ." (22)

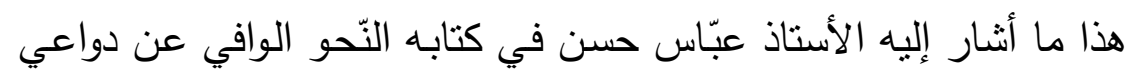

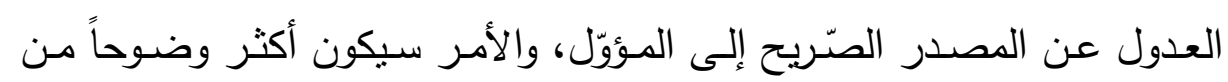

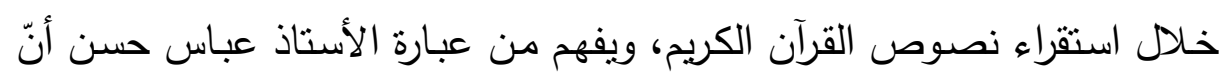

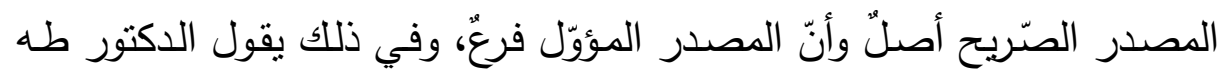

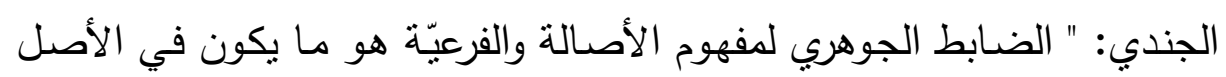

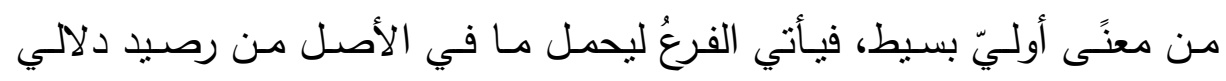

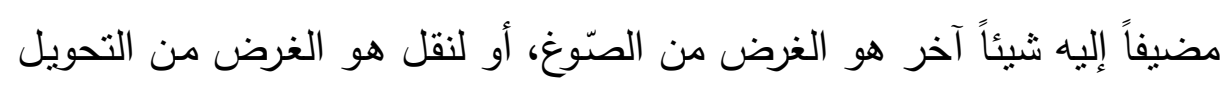

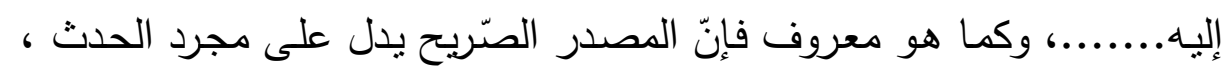

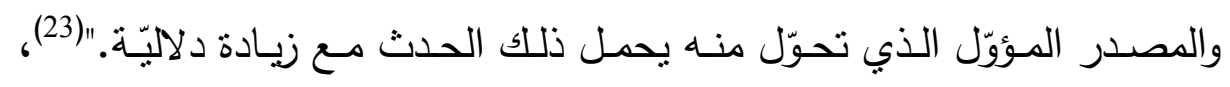

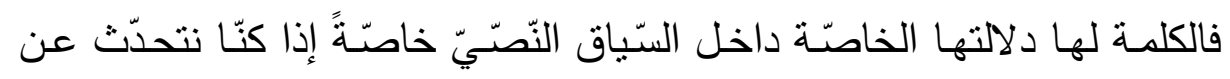
نصِّ لبس من كلام البشر بل هو كلام الهه ربّ العالمين، فلا شك أنّ كلّ مفردة

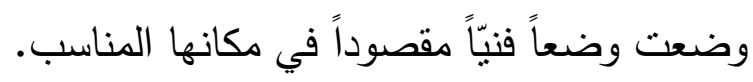

أ.د.إسلام عبد السلام (تحولات المصادر في السياق القر آني دراسة دلالية.........) 
هذا، وقد استعنت في بيان الفروق الدلاليّة للعدول عن المصدر الصّريح

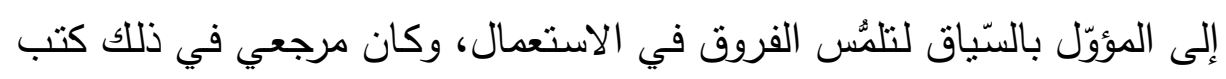

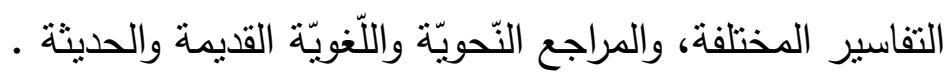

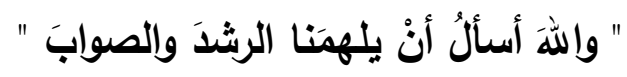




\section{أَنْ يَقْتُلك- قَتَنْ}

قال تعالى

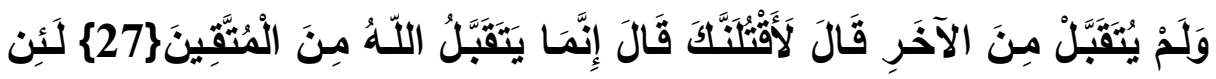

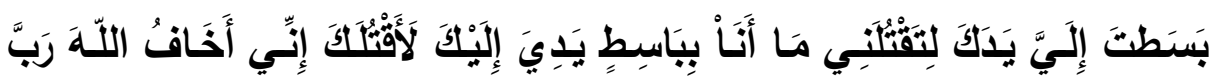

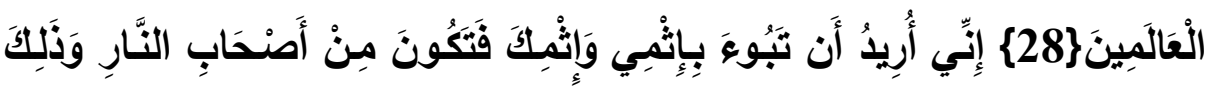

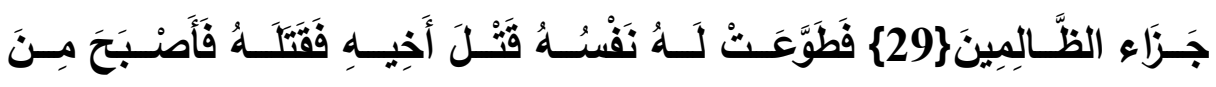
الْخَاسِرِينَ \{30 \{هَه. المائدة: 27-30.

هذه قصّة من قصص القرآن الكريم تقدّم نموذجاً لطبيعة الثَّرِ والعدوان، نموذجاً من العدوان الصارخ الذي لا مبرر له، قصّةٌةٌ ترسم الجريمة المنكرة التي

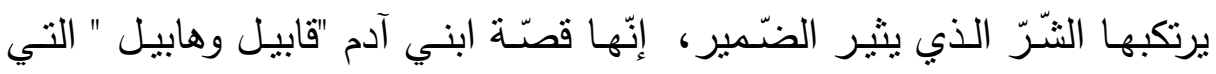

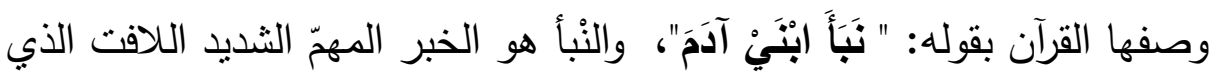
له وقعٌ وأتزرٌ عظيمٌ، والقضيّة كما جاءت في كتب التفاسير (24) أنّ اله تعالى تقبّل القربان من هابيل، ولم يتقبّل من قابيل، وذلك بعدما تقرّب هابيل إلى الله تعالى بخيرِ ماشيتِه، وتقرّب قابيل بأزَدَأ زرعِه؛ ليتزوّج أحدهما من أخت قابيل الجميلة، فوقع الحســ- وهو أوّل جريمـة ظهرت على الأرض - في نفس قابيـل لزواج هابيل من أخته الجميلة، ولتقبّل القربـان منـه، فجـاش في نفسـه خـاطر القتل،

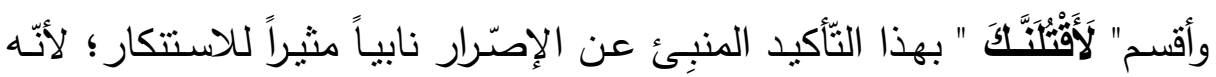
ينبعث من غير موجب، اللهمّ إلا ذلك الثـور الخبيث المنكر، شعور الحسد الأعمي الخارج من نفس شربرة طوّعت وسهّّلت وشجّعت له قتل أخيه. إنّ القتل واقعٌ لا محالة في نفس قابيل، واقعٌ مـع سبق الإصرار والتّرصّد، لقد عزم عليه 
وطوّعته نفسـه، ودفعـه إلى ذلك حسده لأخيه، فعبّر القرآن عن تحقّق الحدث

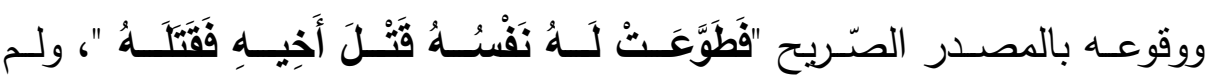
يقل:"فطوّعت له نفسه أنْ يقتل" الذي يشعر معـه القارئ باحتماليّة وقوع الحدث، وأنّ الأمر ليس قطعيّا، وبالفعل وقعت الجريمـة على مسرح الأحداث " فَقَتَلَهُه"، وقد ذللت له نفسُه كلَّ عقبةٍة، وطوّعت له كلَّ مانعِ "فَأَصْبَحَحَ مِنَ الْخَاسِِِينَ". فإذا ما تعلّق الحدث بالظّنّ والهواجس والخوف دون يقين يقطع ويؤكّد هذا الأمر عدل النّصّ القرآنيّ عن المصدرالصّريح إلى المصدر المؤوّل، وضـح ذللك في قولهه تعالى في سورة الثَعراء

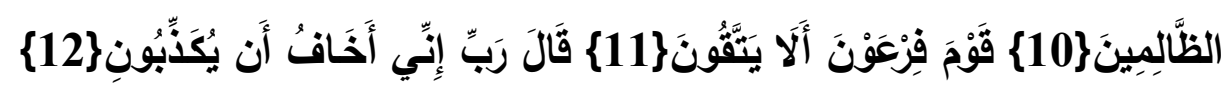

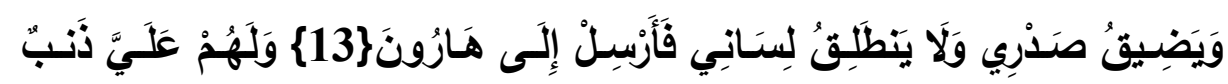

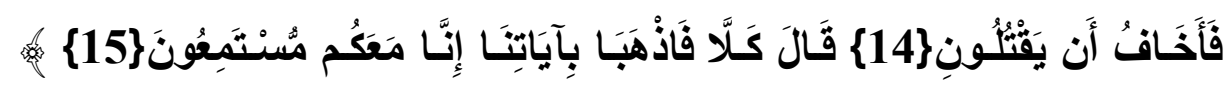
الشعراء: 10-15 - (15. هذا هو المشهد الأوّل في قصّة سيّدنا موسى، مشهد تكليف موسى، وهو

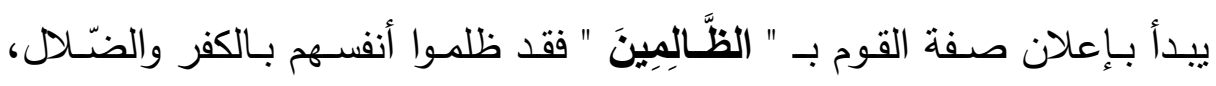
وظلموا بني إسرائيل، فكانوا يذبّحون أبناءهم ويستحيون نساءهم، ولإدراك موسى ظلْمَ فرعون وعتوّه وجبروته، وأنّ مهمّته ضخمة وتكليفه عظيم، شكا إلى ربّه ما به من ضعفٍ وقصور ، وأبدى هواجس نفسه وخلجاتها لا ليعتذر، ولكن ليطلب

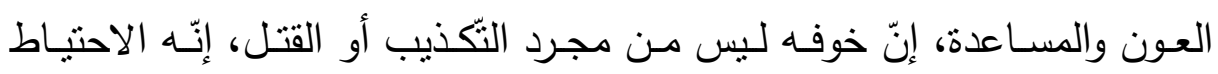
للدّعوة كما يقول الأستاذ سيّّ قطب في ظلال القرآن (25). وليس أيضـاً تلكاً في

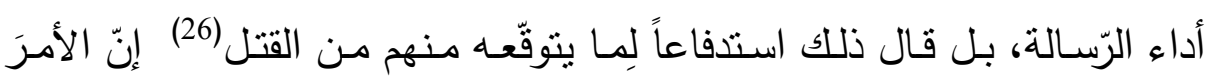


مجردُ ظنّ وتوقّع وخـوف من قوم جبّارين؛ لذا ناسـب تلك الإثـارات التعبير

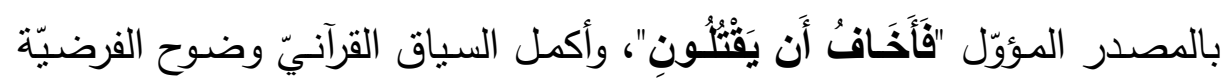
الظنيّة لدى موسى -عليه السّّلام - بقوله: "كلا "، أب: كلا لن يقتلوك، فهو ردعُ

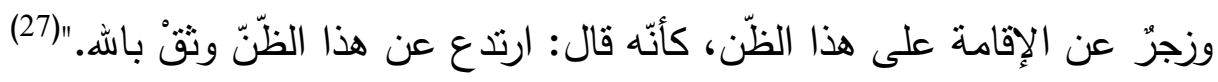
وإذا جاورنا بين الآيتين ظهر الثنّاسق القرآنيّ وأنّ الجملَ القرآنيّة منتاسقة

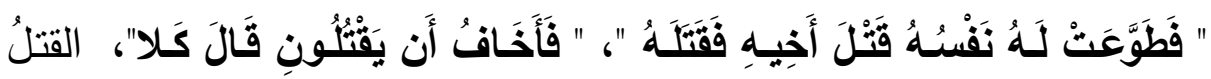
متحقّق في نفس القاتل - قابيل-( مصدر صريح)، فظهر على مسرح الأحداث " فَفَتََهُ "، والقتل أمرٌ ظنّيّ في نفس موسى غير متحقّق (مصدر مؤوّل)، فأمره القرآن أنْ يرتذع عن هذا الظنّ ويثثق بالله. 


\section{أَن تَصُومُواً - صيام}

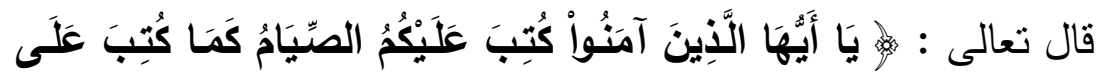

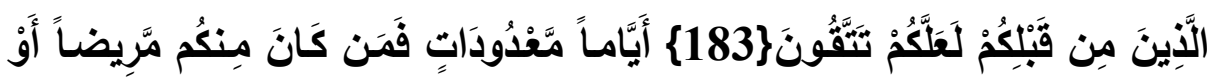

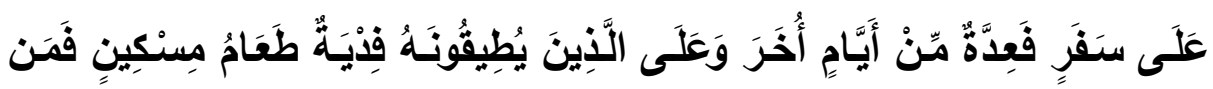

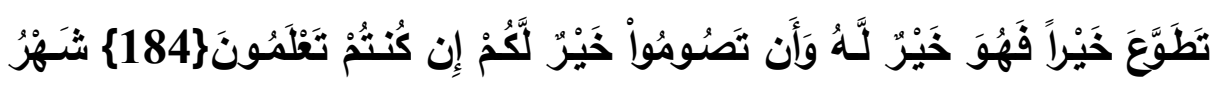

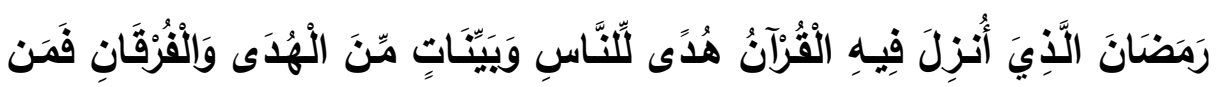

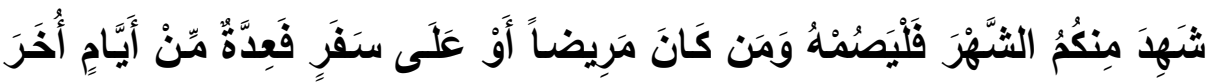

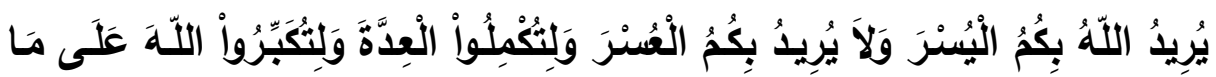

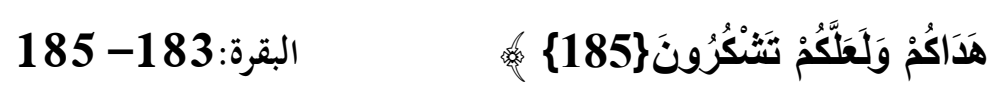

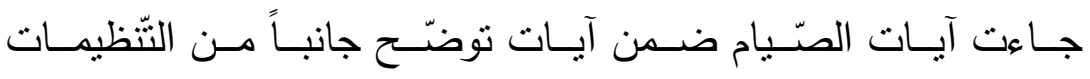

الاجتماعيّة للمجتمع الإسـلاميّ في بداية عهده بالمدينة، وجانباً من العبادات المفروضة كلّها مرتبطة بالوجوب وبتقوى الله تعالى وخشيته.

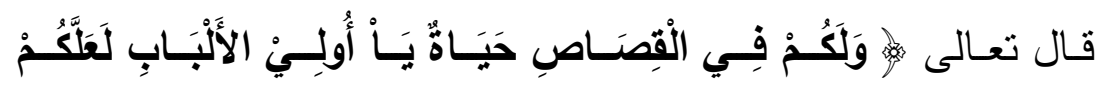

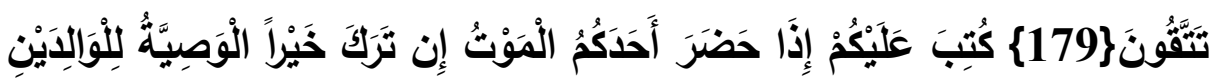

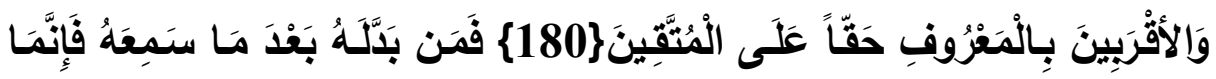

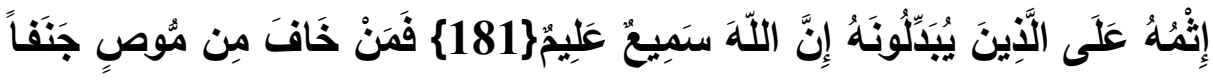

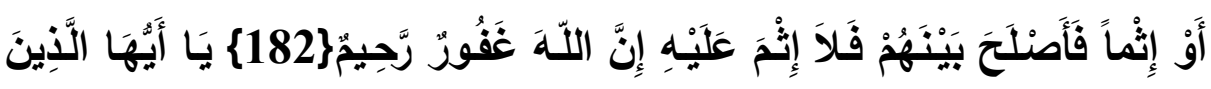

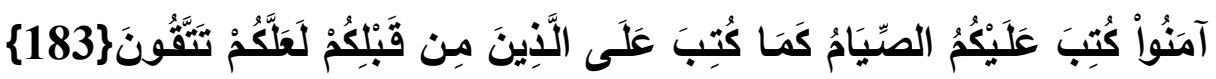

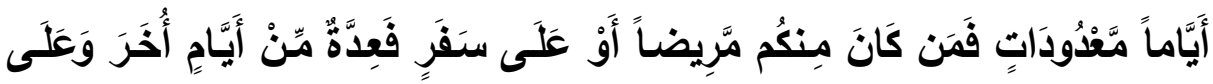

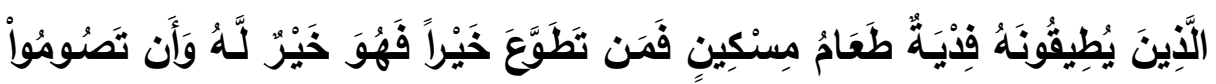




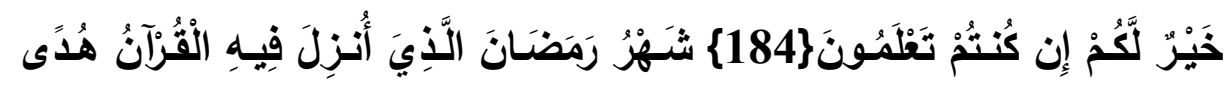

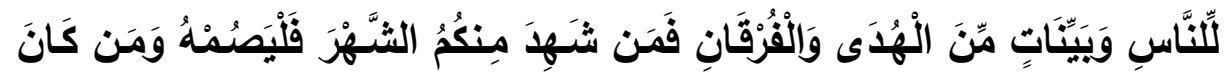

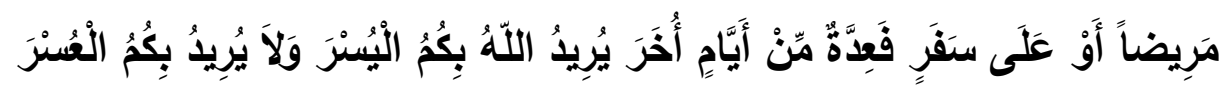

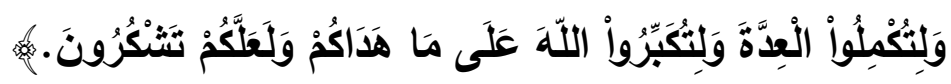
ويلاحظ في الآيـات السـابقة أنّها خاطبت المجتمع المسلم بتنظيمات

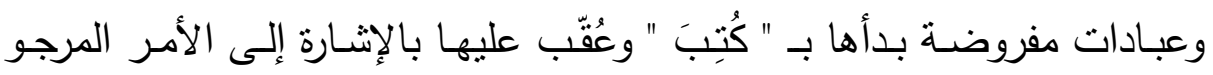

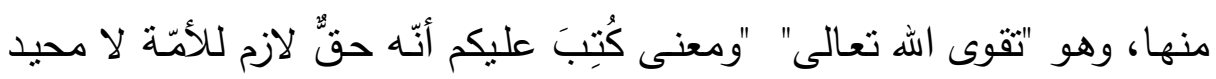

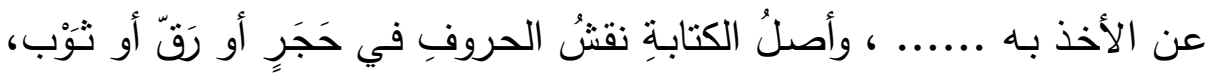

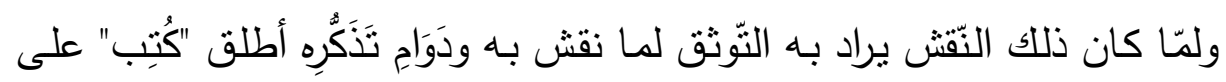

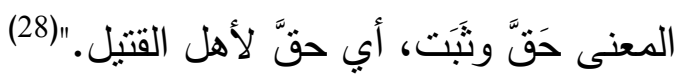

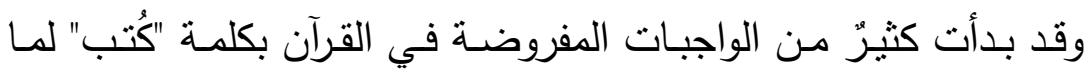

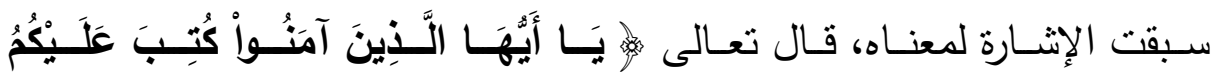

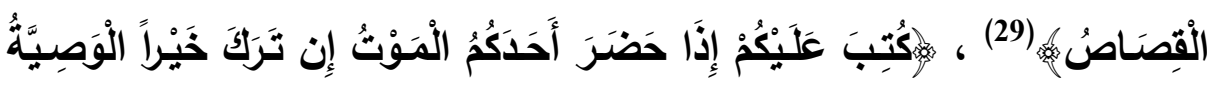

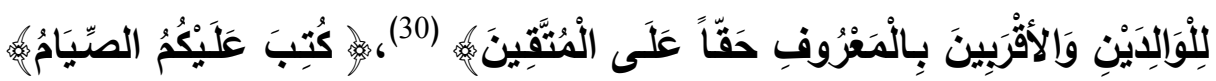

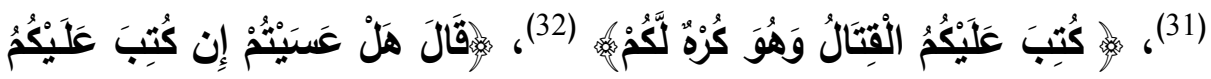

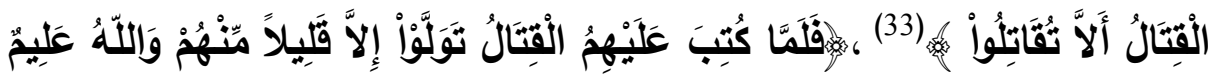

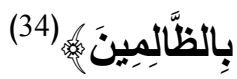
إذاً فالقرآن الكريم يقرر أنّ الصّيام فريضة قديمة على المؤمنين باله في

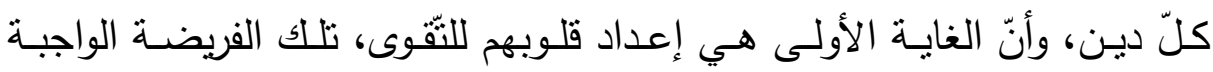
ناسبها التعبير بالمصدر الصتريح "الصيّيام". 
ثمّ عَقِبَ القرآن لذلك الحكم الوجوبيّ بحكم الرّخصـة، حيث أعفى من

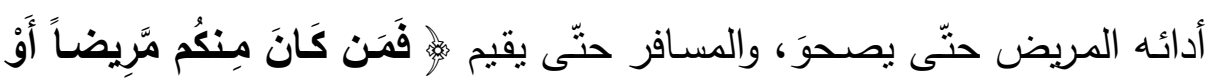

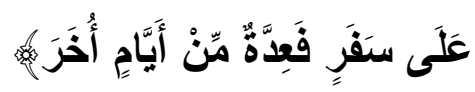
ولمّا كان الصيام شاقاً على المسلمين في أوّل الأمر - حيث فُرض السّنة الثانية من الهجرة- فقد جعل الله فيه رخصـة لمن يستطيع الصيام بجهد، وهذا الرّخصــة هـي الفطر مـع إطعـام مسكين، وهذا معنـاه "أنّ الآيـة دلّت على أنّ

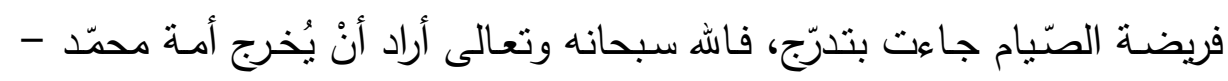
صلّى الله عليه وسلّم - من دائرة أنّهم لا يصومون إلى أنْ يصوموا صياماً يخيّرهم

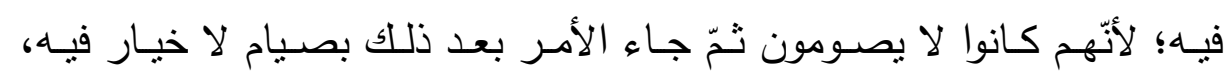

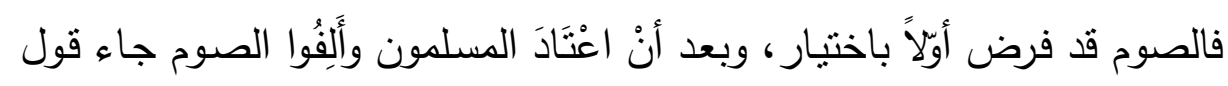

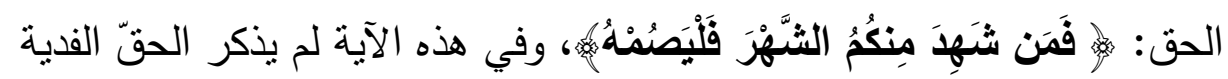

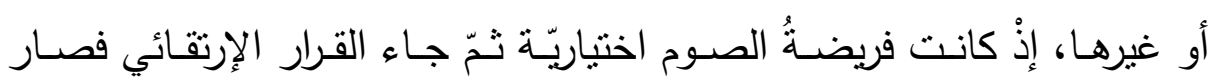
الصـوم فريضــة محدّدة المدّة وهي شـهر رمضـان، وبـذلك انتهـت مسـألة الفديـة بالنسبة لمن يطيق الصّوم، أمّا الذى لا يطيق أصسلاً بأنْ يكون مريضاً أو شيخاً

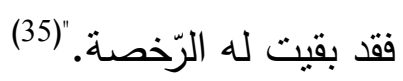

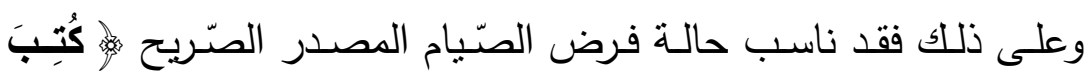

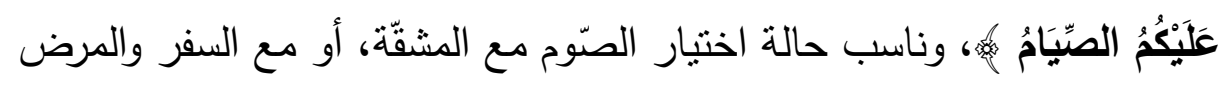

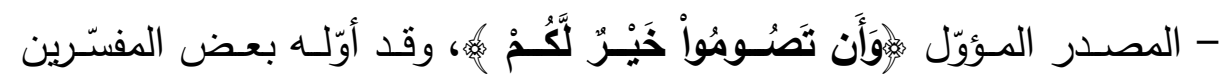

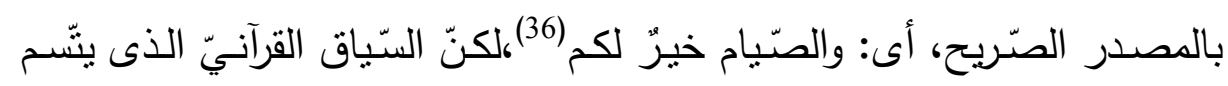

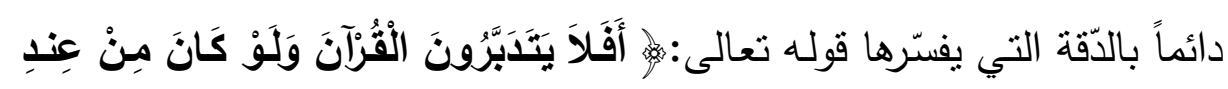




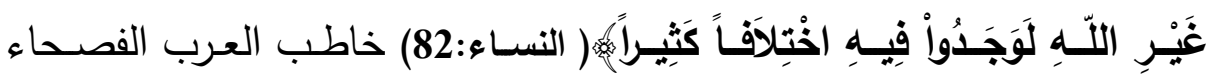
بالمصدر الصَّريح لبيان وجوب فريضة الصيام، وبالهصدر المؤول لبيان اختبار

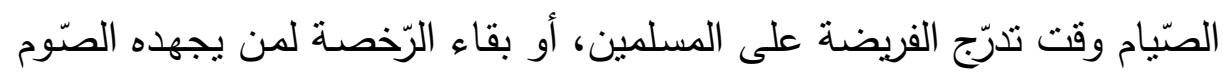
أو كان مريضاً أو مسافراً.

\section{أنْ تجمعوا - جمع}

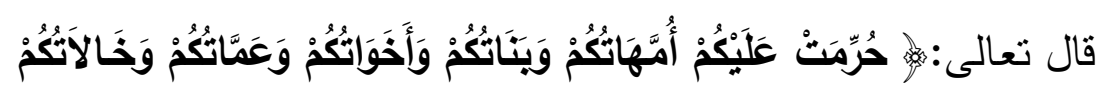

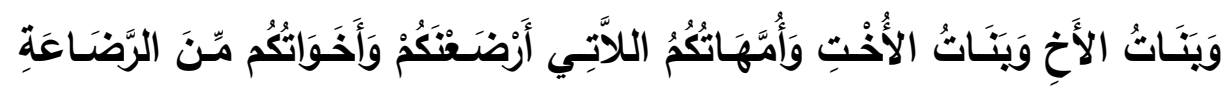

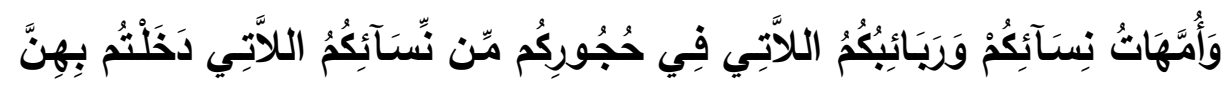

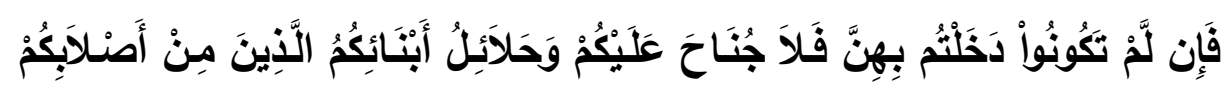

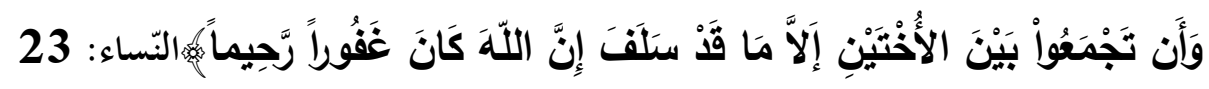

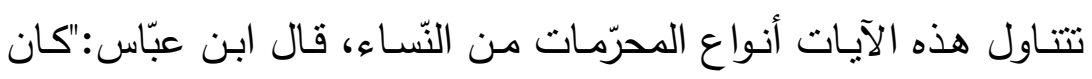

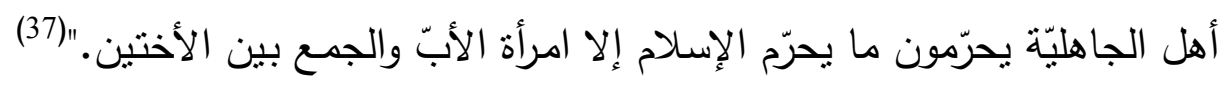

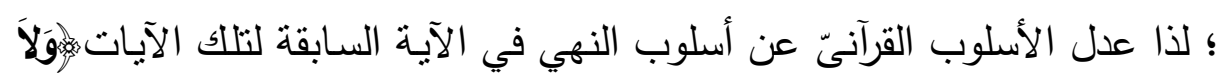

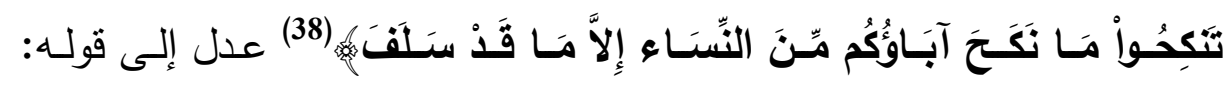

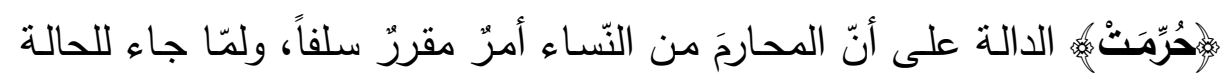

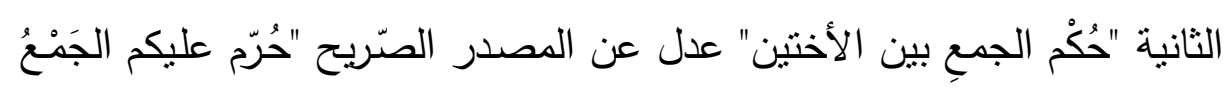

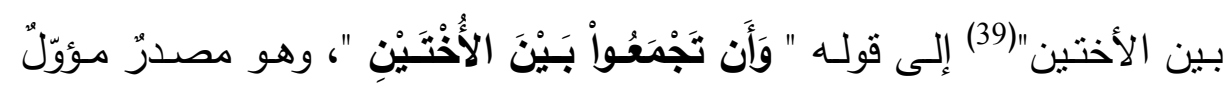

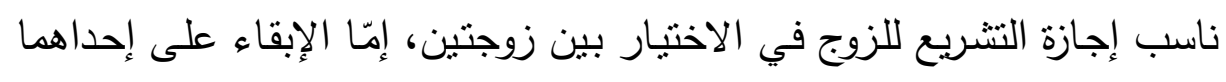

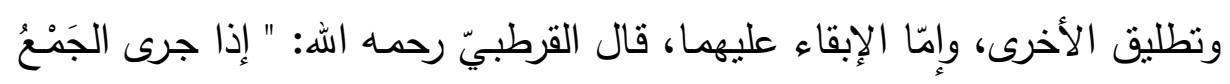

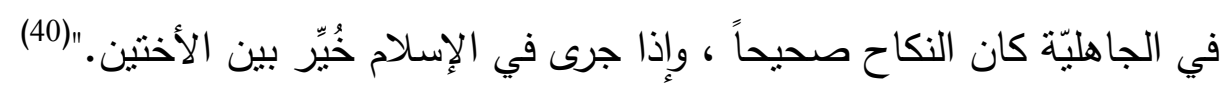


قال الإمام الثَّعراوي: " إنّ هذا الأمر - الجَمْع بين الأختين - قد سلف قبل

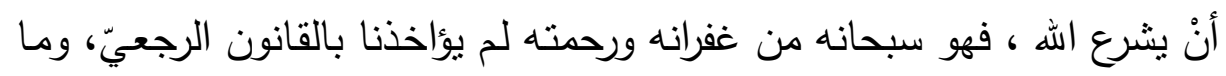

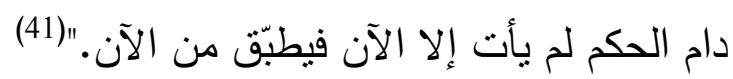

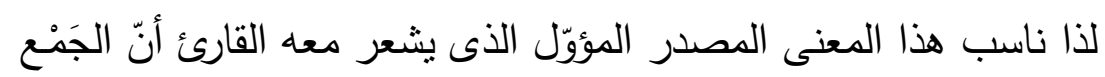

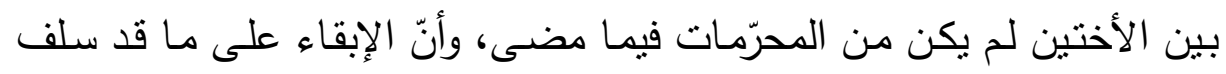
اختياريّ، وأنّ الله يغفره والإسلام يحببه، ويدلّ على عدم المؤاخذة به. (42)

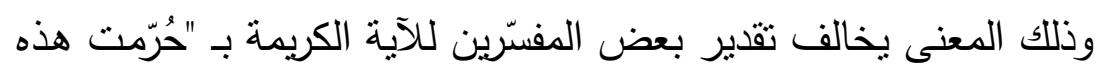

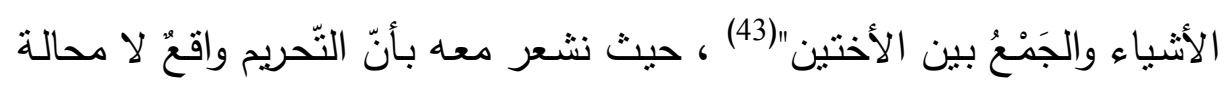

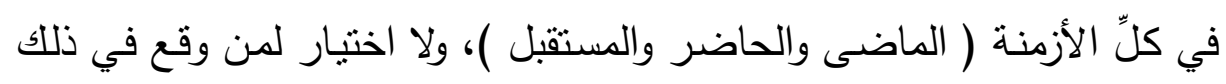

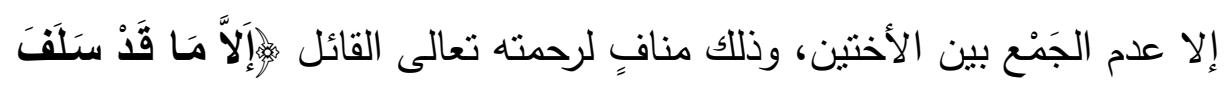

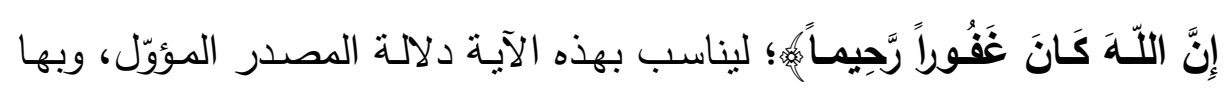

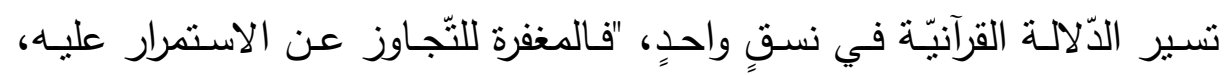

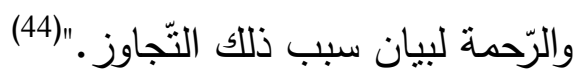

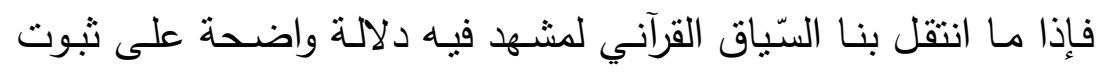

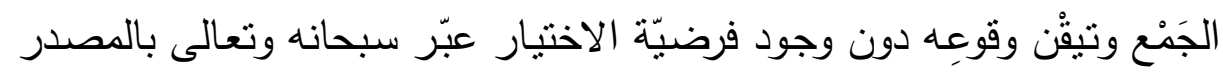

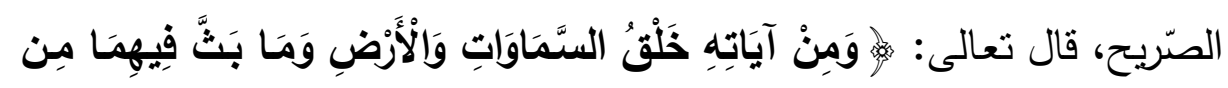

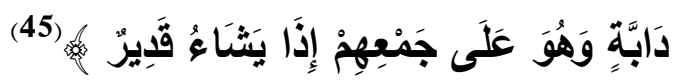
جاءت الآية الستّابقة ضمن آيات تتحدّث عن آثار قدرة الله فيما يحيط

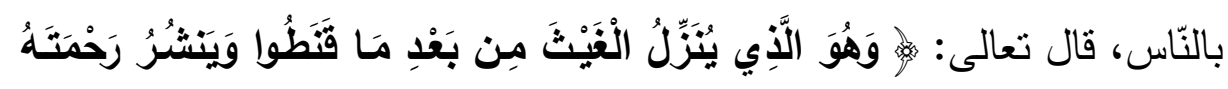

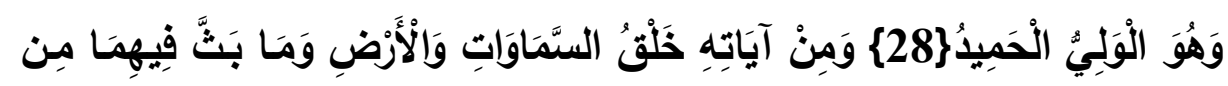




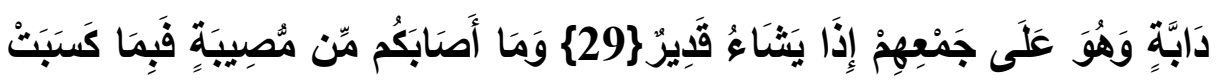

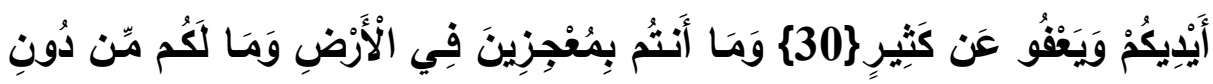

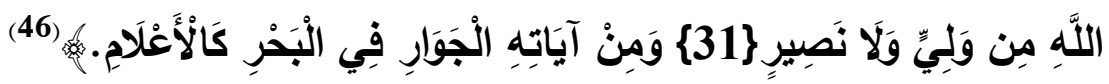

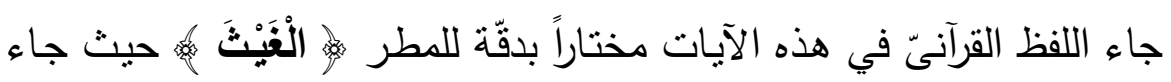
ليلقى ظلّ الغوث والنّجدة، وتلبية المضطر في الضّيق والكربة، كما أنّ تعبيره

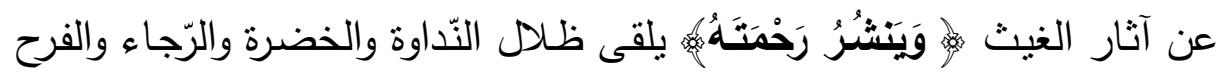
التى تتشأ فعلاً عن تقتّح النبات في الأرض وارتقاب الثّمّار .

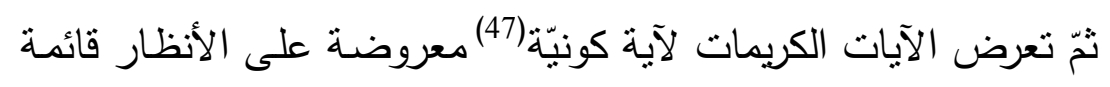

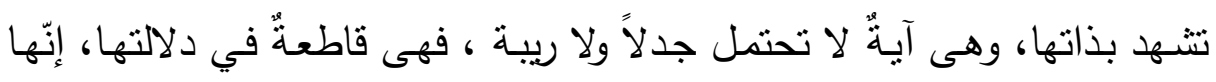

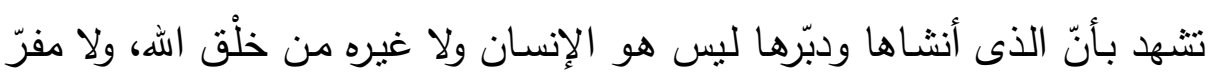
من الاعتراف بمنثِيَئ مدبّر ، فإنّ ضخامتها الهائلة، وتتاسقها الدّقيق ونظامها الدّائب ووحدة نواميسها الثّابتة لا يمكن تفسيره إلا على أسـاس أنّ هناك إلهاً

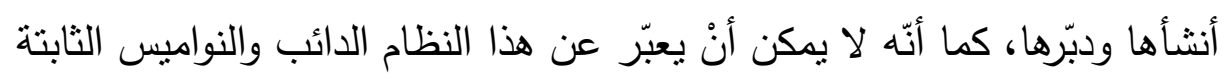

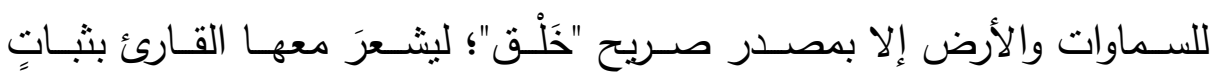

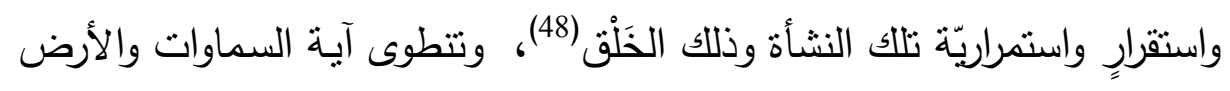

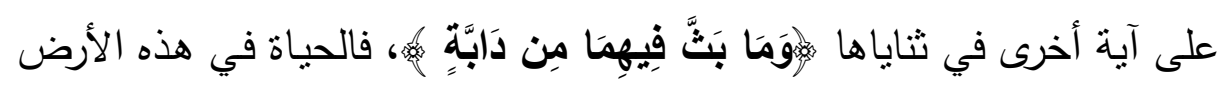

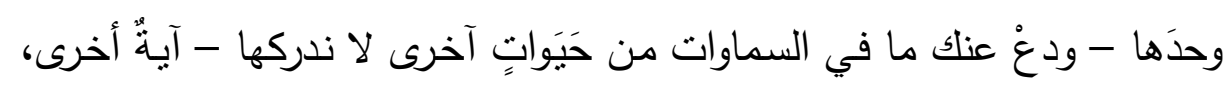

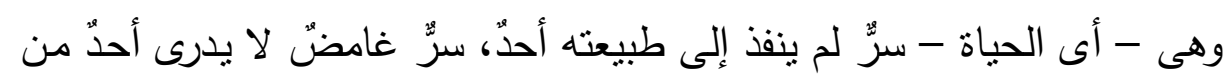

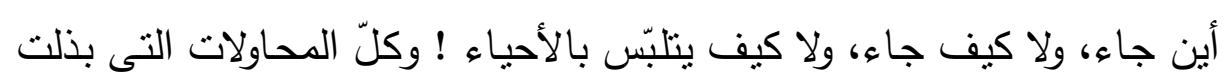

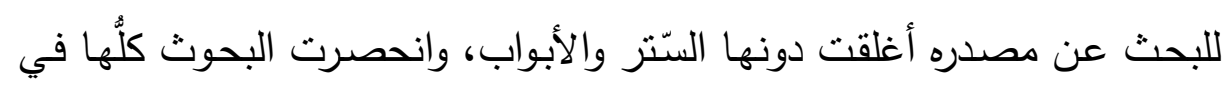


تطوّر الأحياء بعد وجود الحياة، هذه الأحياء المبثوثة في كلٍّ مكان فوق سطح

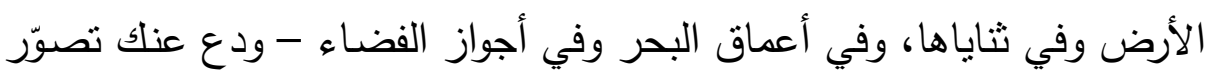

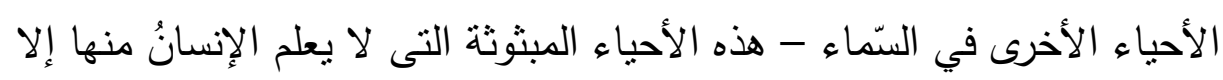

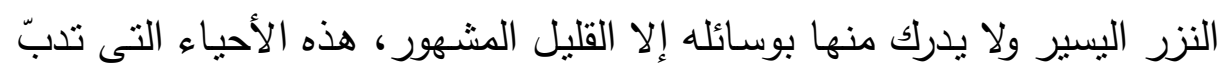

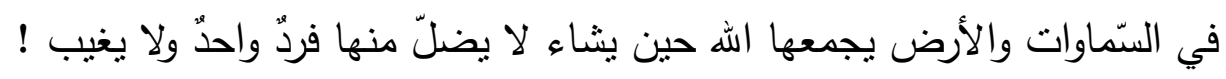

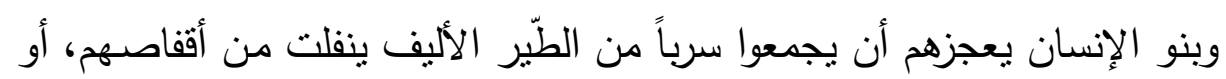

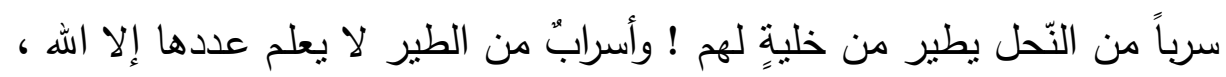

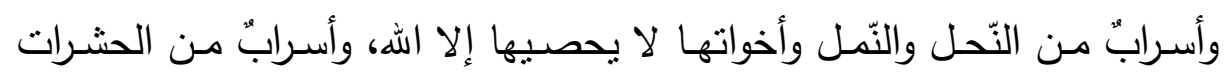

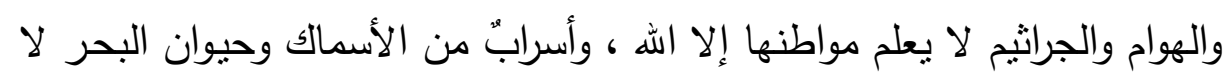

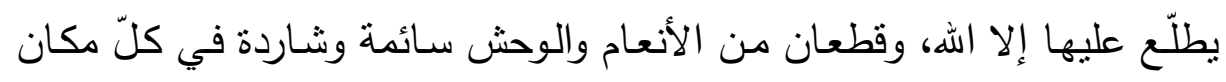

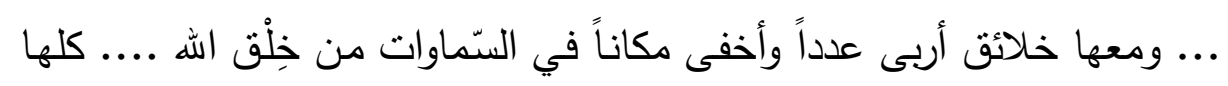

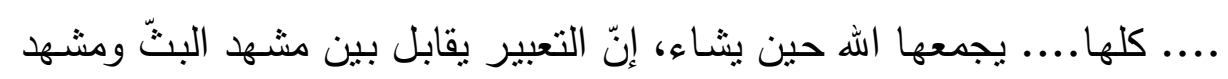

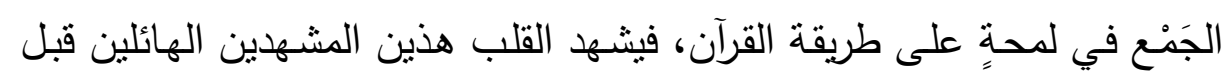

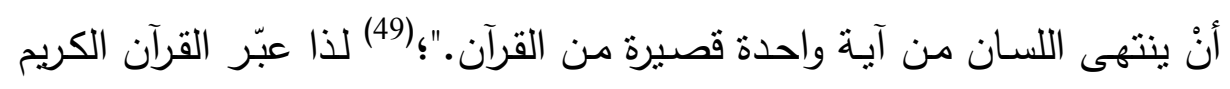
عن تلك القدر العظيمة بمصدرٍ صريحٍ " خَلْق - جَمْع "؛ ليناسب شعورنا باليقين الكامل بقدرته تعالى على خَلْق وجَمْع نلالك الخلائق .

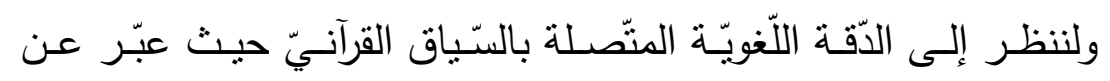

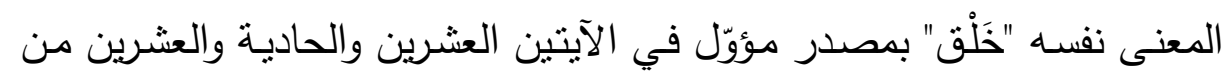

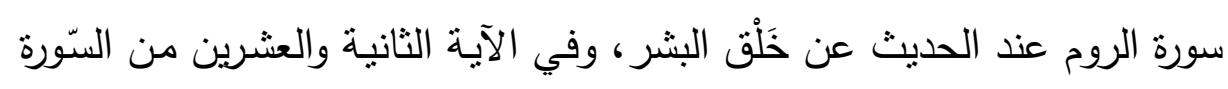

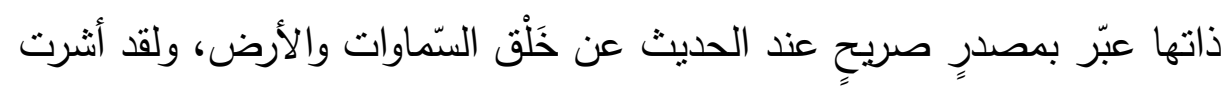


آنفاً إلى دلالـة التّعبير بالمصدر الصتريح "خَلْق " في سورة الثورى، وبقى أنْ أثشير إلى العدول عنه في الآيتين العشرين والحادية والعشرين من سورة الروم قال

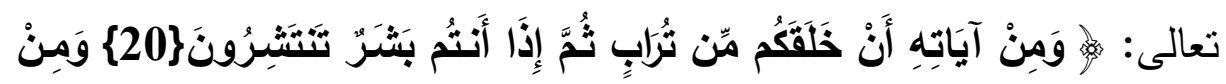

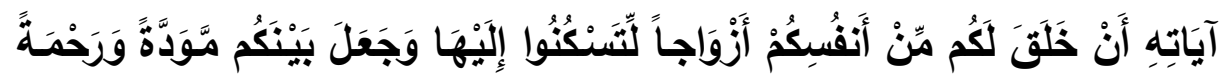

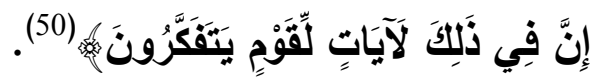

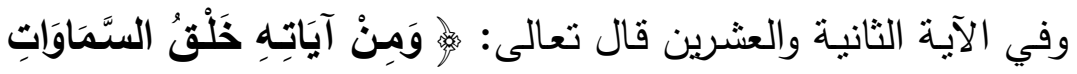

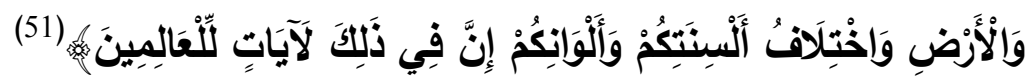

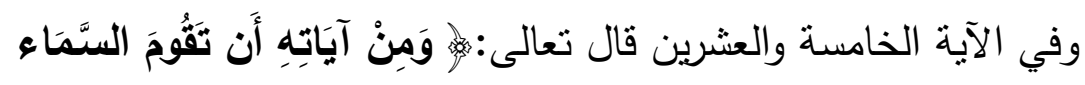

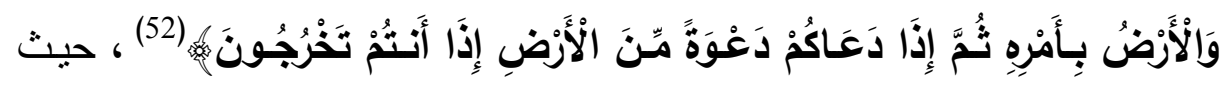
عدل في حديثه عن السماء والأرض عن المصدر الصريح " خَلْق" إلى المصدر

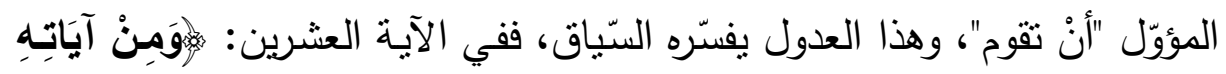

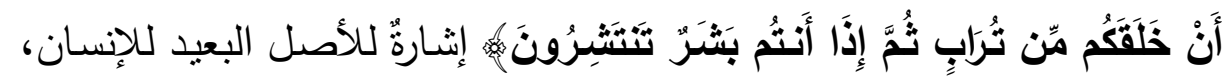

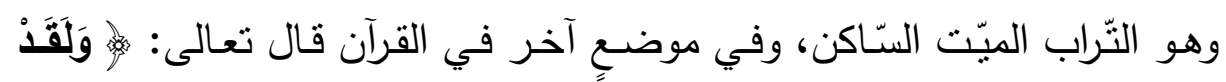

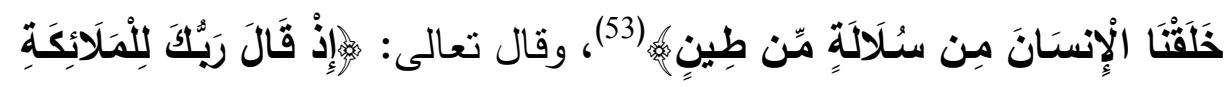

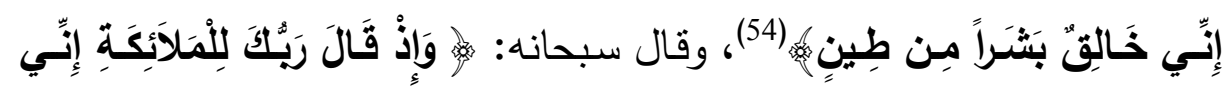

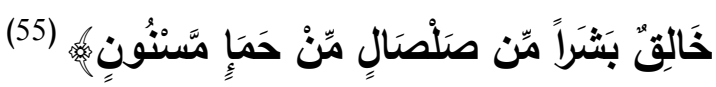

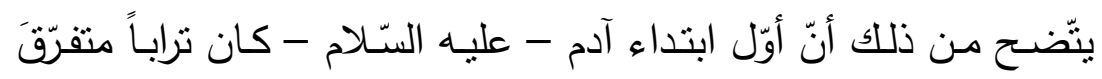

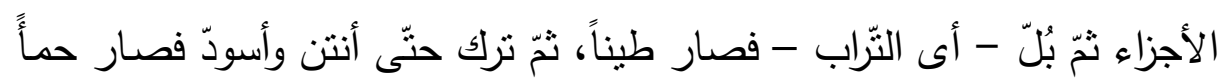

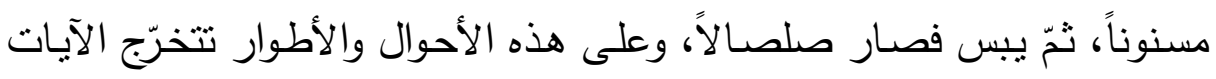

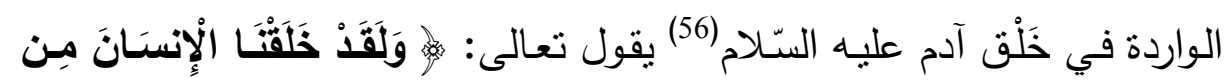




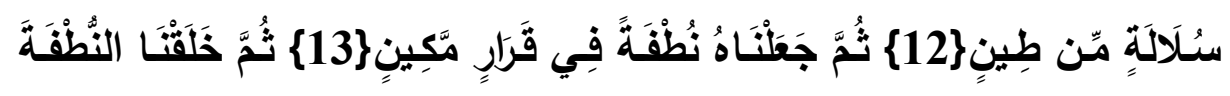

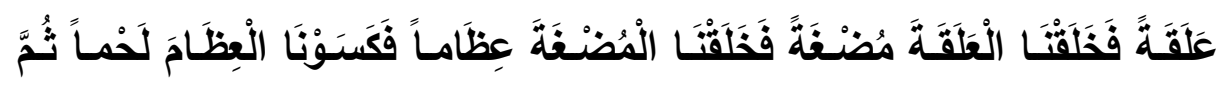

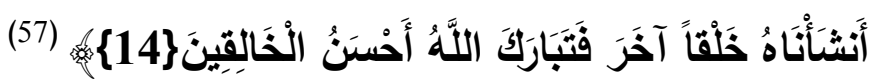

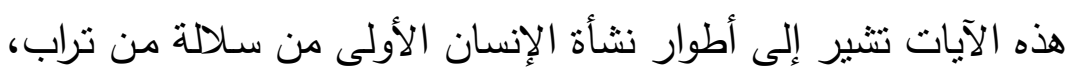

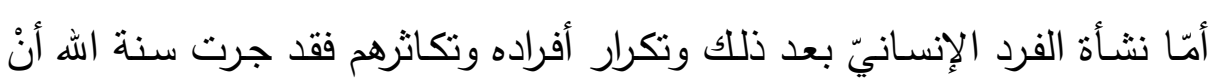

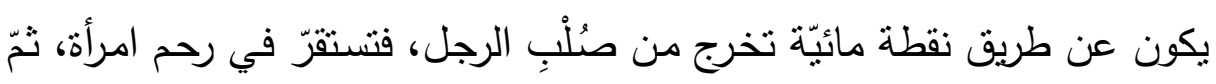

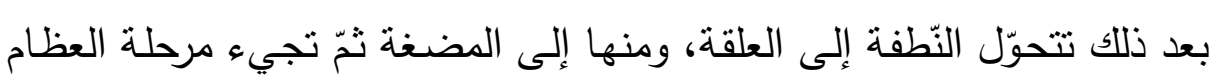

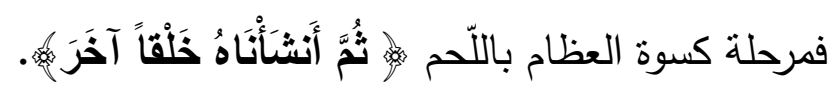
يتّضح ممّا سبق أنْ خلق الإنسان من ترابٍ خاصنٌ بآدم عليه السّّلام وأنّه

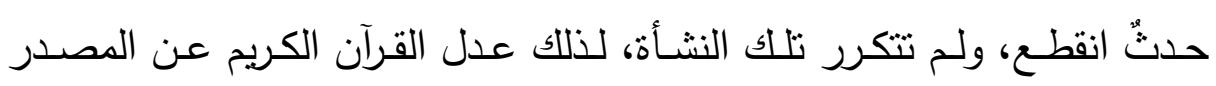

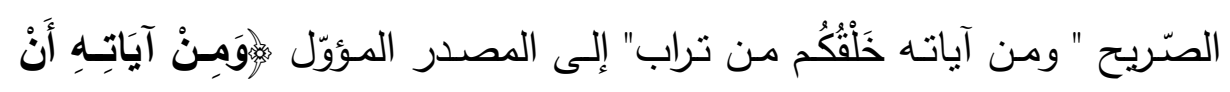

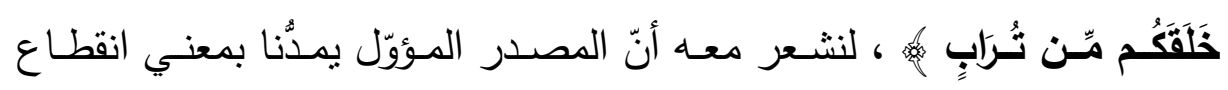

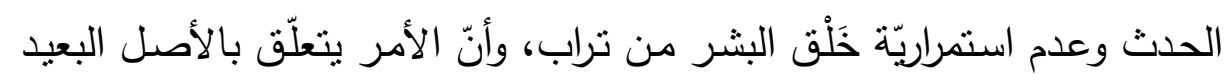

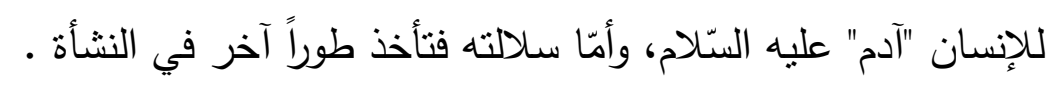

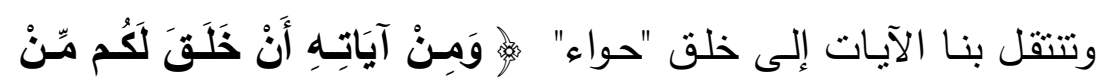

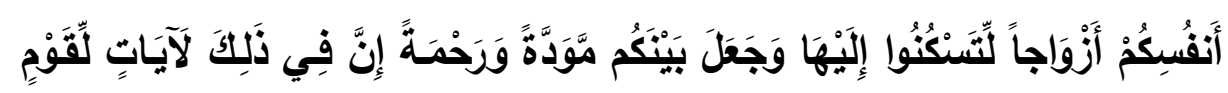

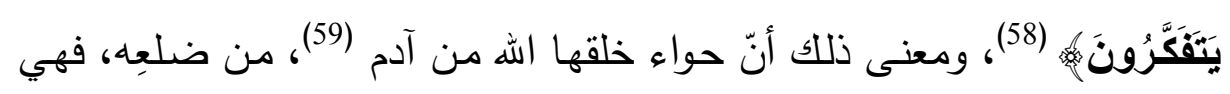

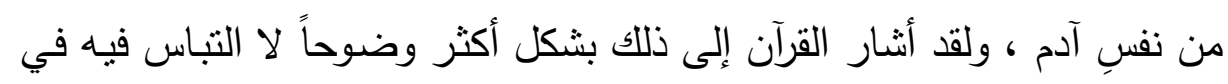

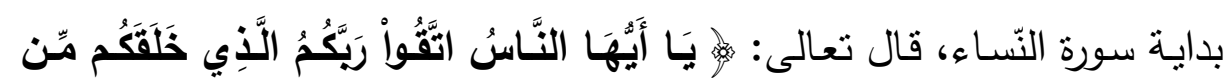

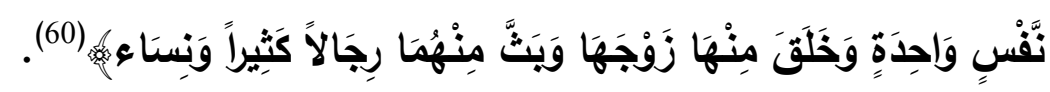

أ.د.إسلام عبد السلام

(تحولات المصادر في السياق القرآني دراسة دلالية.........) 


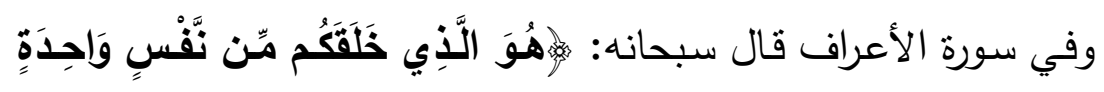

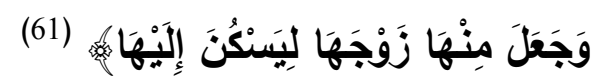

وفي الحديث الصحيح : "إنّ المرأة خُلِقَت من ضلع، وإنّ أعوج شيء في

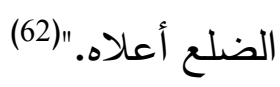

جاء في التّحرير والتّوير عند تفسير آية سورة النّساء:" والنّفس الواحده

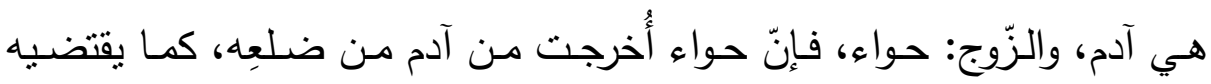

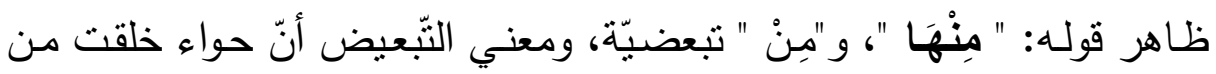

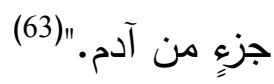

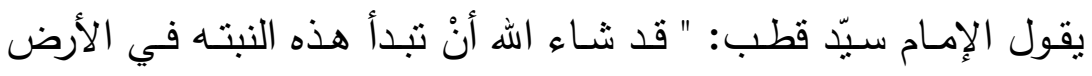

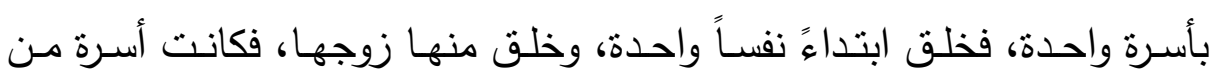

زوجين." (64) - ن

يتضتح مما سبق أنْ خلق حواء من ضلع آدم -عليه السّّلام - حدثُ لم

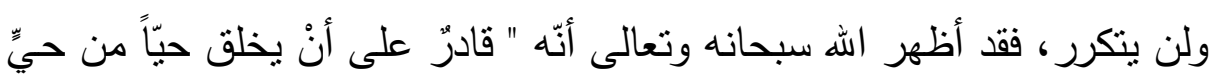

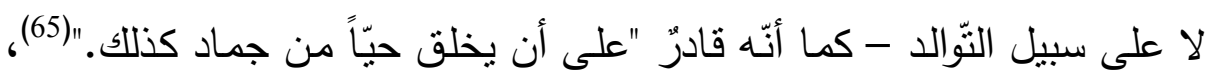

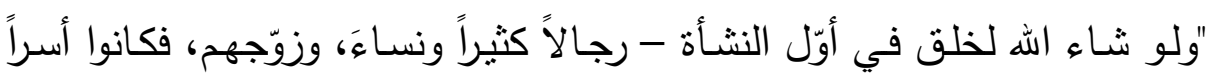

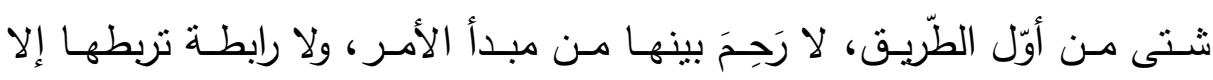

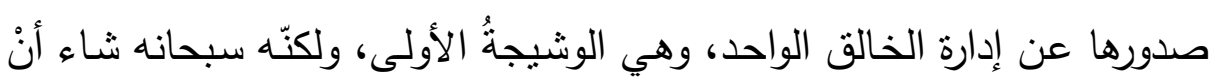

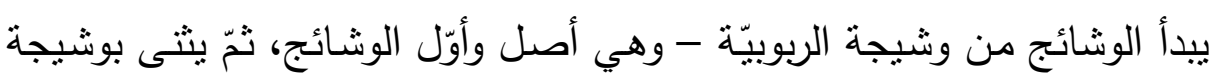

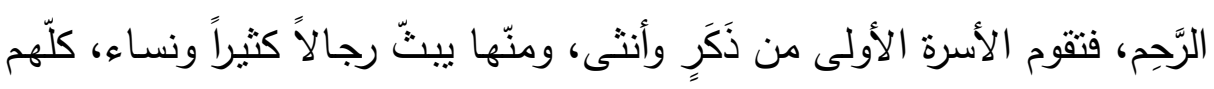

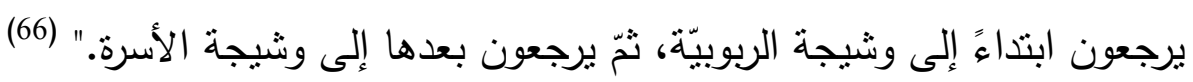

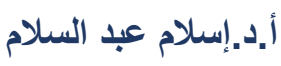

(تحولات المصادر في السياق القر آني دراسة دلالية..........) 
هذه المعاني عبّرعنها المولى سبحانه وتعالى في سورة الروم بمصدٍٍ

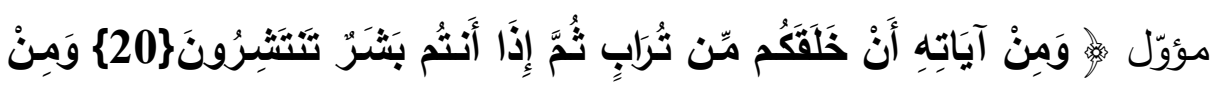

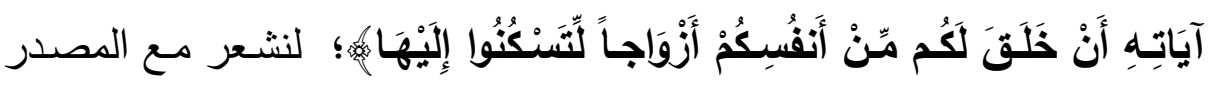

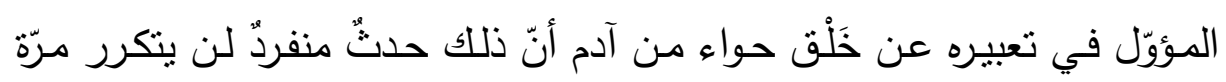

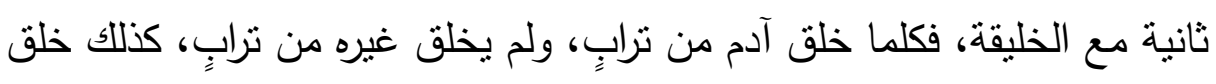

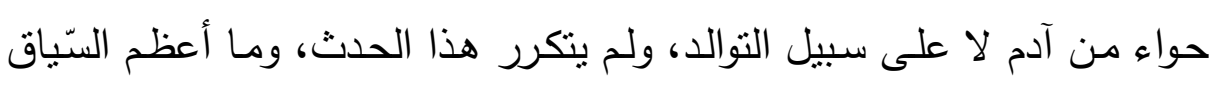

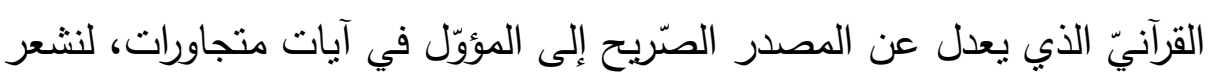

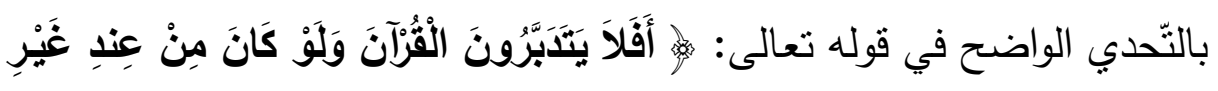

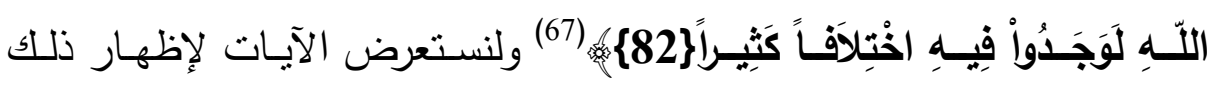
العدول:

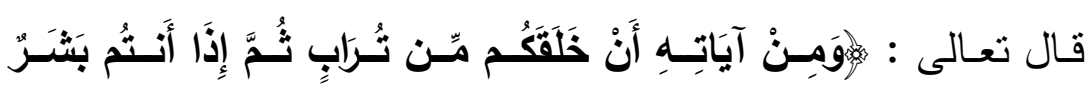

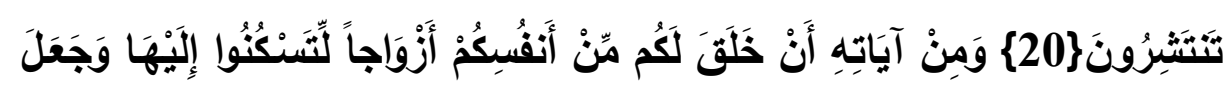

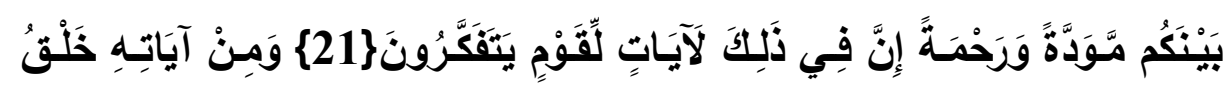

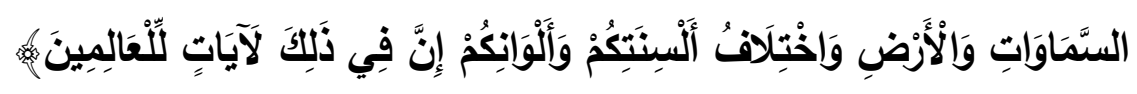

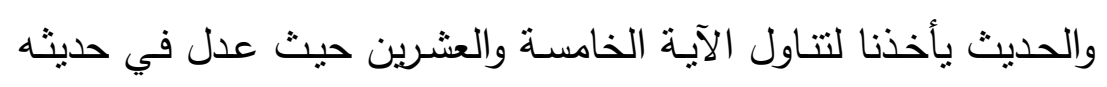

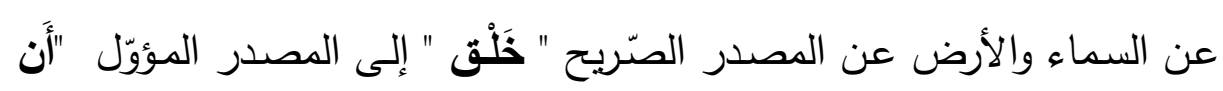

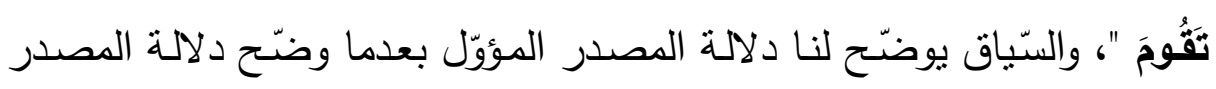

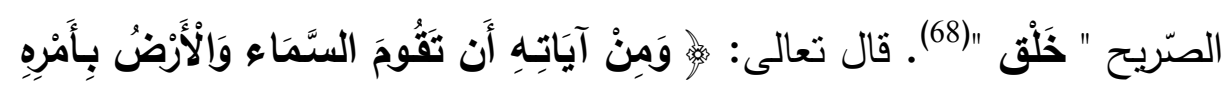

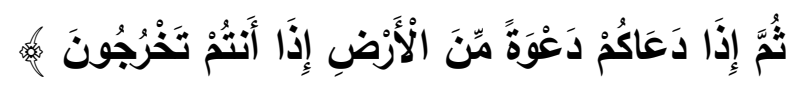




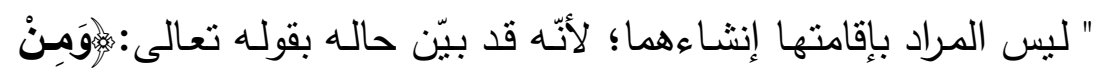

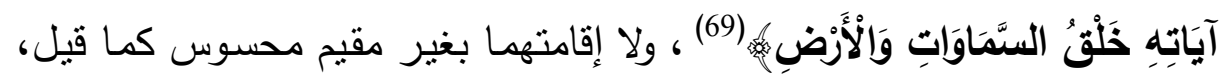
فإنّ ذلك من تتمات إنشائهما، وإنْ لم بصرح به تعويلاً على ما ذُكر في موضِّ

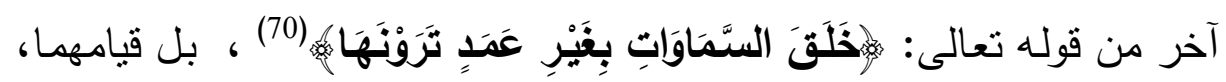

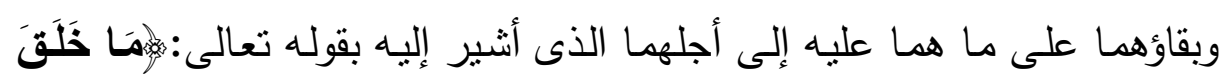

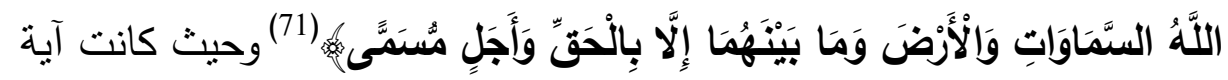
قبام السّماء والأرض بأمره تعـالى متأخّرة عن سـائر الآيـات المعدودة، متّصلة بالبعث في الوجود أخّرت عنهنّ، وجعلت منّصلة به في الذّكر أيضاً فقيل :" وَمِنْ

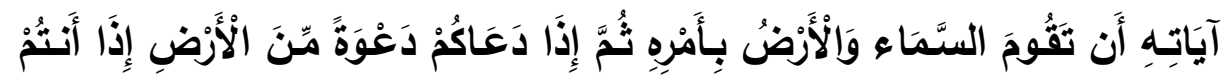
تَخْرُجُهونَ "، والكـلام مسـوق للأخبـار بوقوع البعـث ووجـوده بعد انقضـاء أجلـل قيامهما، كأنّه قيل: ومن آياته قيام السّماء والأرض على هيئتهما بأمره عزّ وجلّ إلى أجلٍ مسمّى قدّره الله تعالى لقيامهـا، ثم إذا دعاكم أى بعد انقضـاء الأجل في الأرض وأنتم في قبوركم دعوة واحدة بأنْ قال سبحانه: أيها الموتى اخرجوا

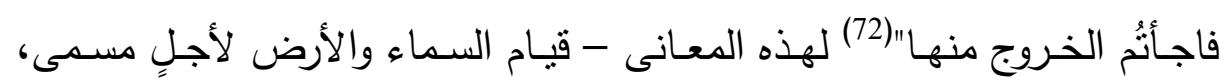
واتّصالها بالبعث - عدل القرآن الكريم عن المصدر الصّريح " ومن آياتهـه قيام"

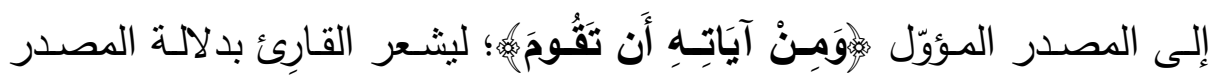

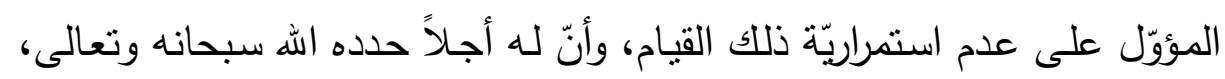
وعبّر بـثثّ " للتّراخي وبيان طول فترة قيام السّماوات والأرض لحين موعد الحشر ، و "المقصود من الجملة المعطوفة الاحتراس عمّا قد يتوهمّ من قوله " أَن تَقَوْمَ الستَمَاء وَالْأَرْضُ بِأَمْرِهِ " من أبديّة وجود السّماوات والأرض فأفادت الجملة أنّ 
هذا النّام الأرضيّ يعتوره الاختلال إذا أراد اله انقضاء العالم الأرضيّ وإحضار

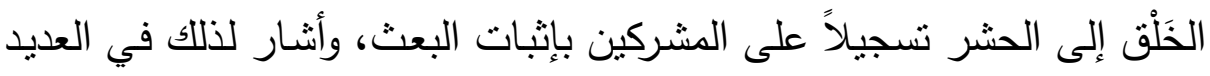

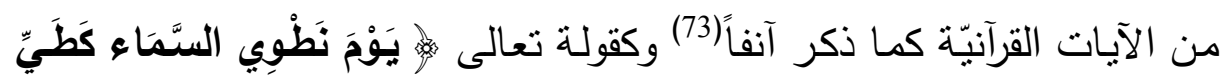

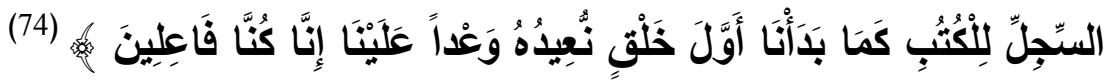

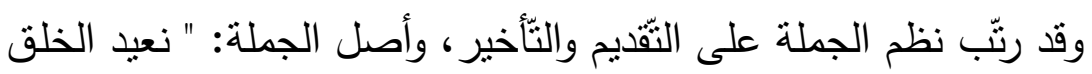

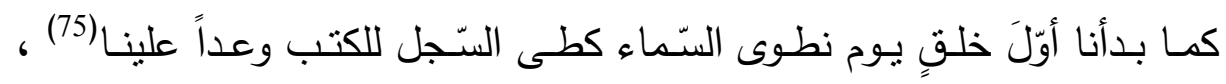
فالسّماء مطويّة كما يطوى خازن الصحائف صحائفه، وقد قضى الأمر ، وطوى الكون الذى كان بألفه الإنسان، وإذا عالم جديد وكون جديد."(76) أَنْ تَأَخْنَ - أَخْنْ

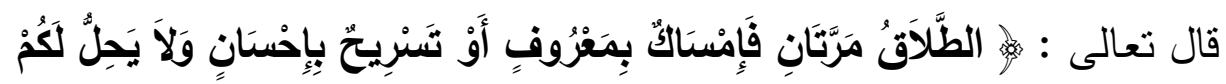

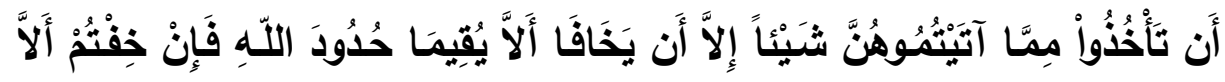

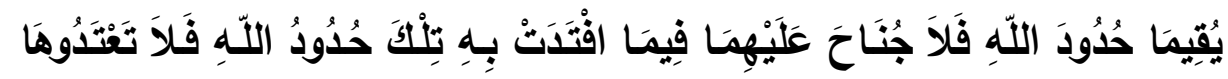

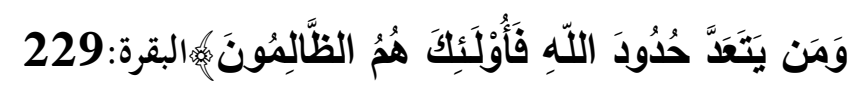
نزلت هذه الآيات بياناً لعدد مرات الطَّلاق الذى للمرءء فيه أنْ يرتجع دون

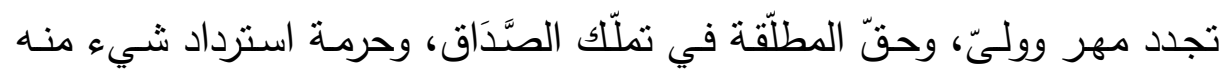

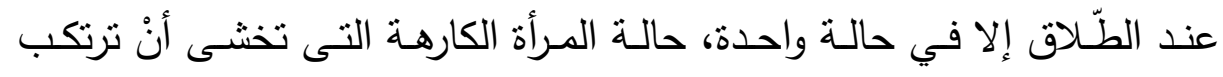
معصيّة لو بقيت مقيّة بهذا الزواج المكروه، وهى حالة الخلع، التي تثترى فيها

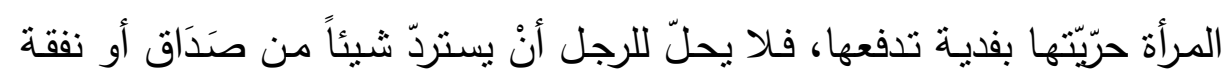

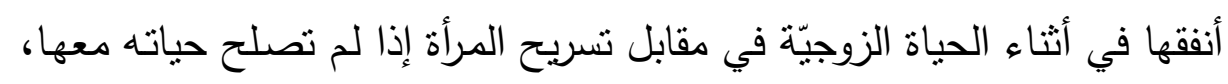

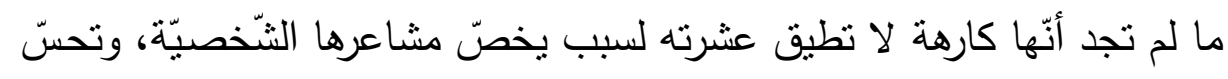


أنّ كراهيتها لـه، أو نفورها منه سيقودها إلى الخروج عن حدود الله في حسن

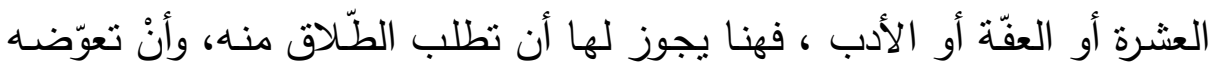

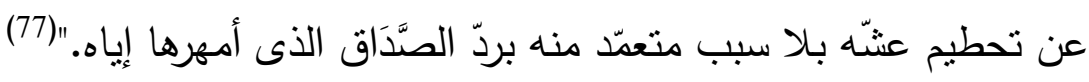
ولقد روى البخاريّ بإسناده عن ابن عباس رضى الله عنهما- أنّ امرأة

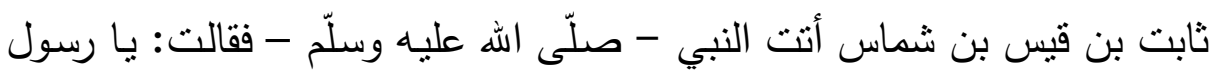
الهه ما أعيب عليه في خلقٍ ولا دينٍ، ولكن أكره الكفر في الإسلام، فقال رسول

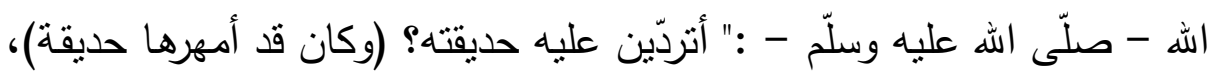

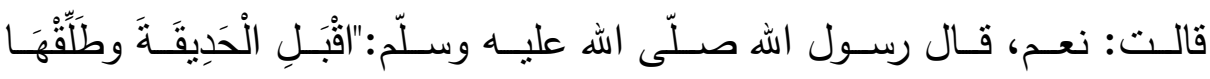

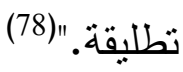

والدفهوم من سياق الآيات السابقة أنّه يجوز أنْ يأخذ الزوج من زوجته

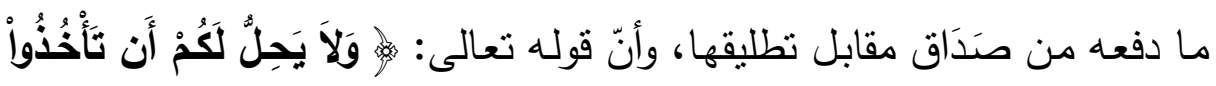

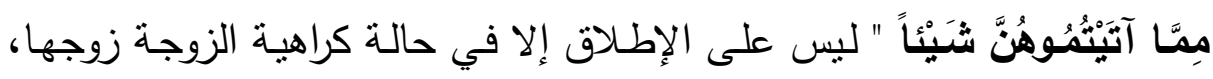

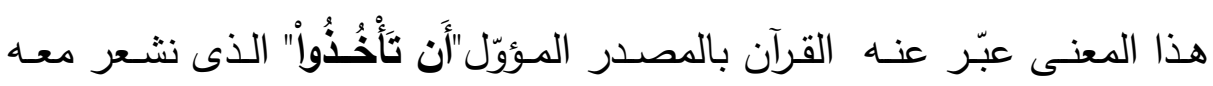

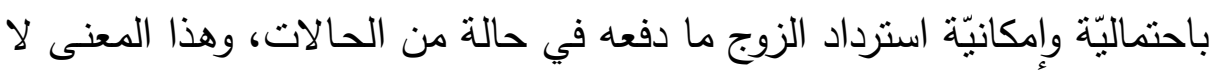

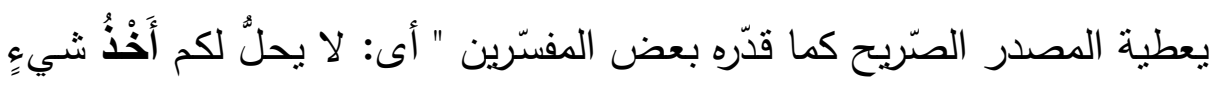
مما أتتيتموهنّ." (79)

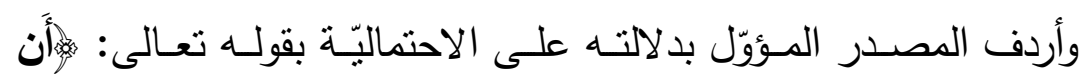

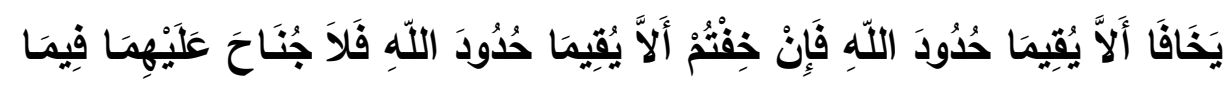

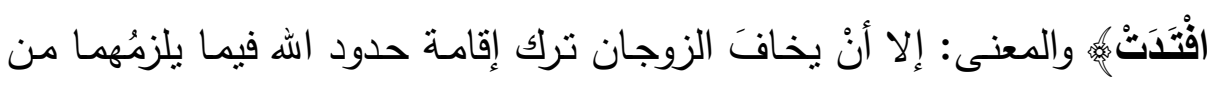

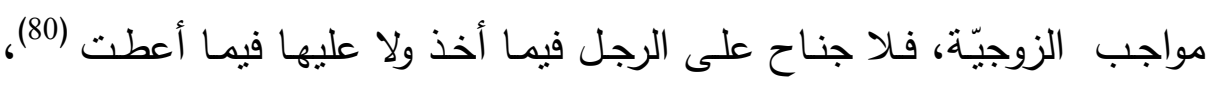


وبذلك يسير التعبير القرآني في نسقٍ واحدٍ مُنتابعٍ غير منتاقض، وتتضّح دلالة

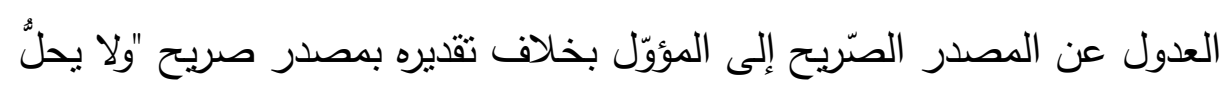
لكم أَخْنُ شيءٍ مها أتبتموهنّ إلا أنْ يخافا ألا يقيما حدود الله فإنّ خفتم ألا يقيما حدود الله فلا جناح عليهما فيما افتنات به "، حيث بظهر التباين بين بداية الآية "عدم الأخْذِ" وما تشعِه من دلالة على ثبات الحُكْم وقطعيته وبين بقية الآيَة بما تشتمل عليه من استثناء يبيح للزوج استراد ما أنفقه، فلا يضيع عليه بـلا ذنب جناه.

فإذا مـا تحدّث القرآن الكريم عن "أخْذٍ " لا احتماليّة فيه وأنّه لا محالةَ

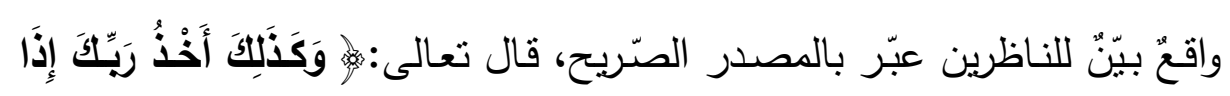

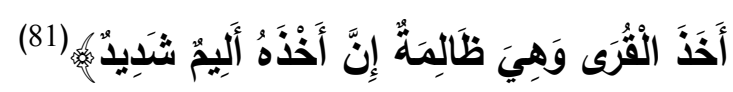

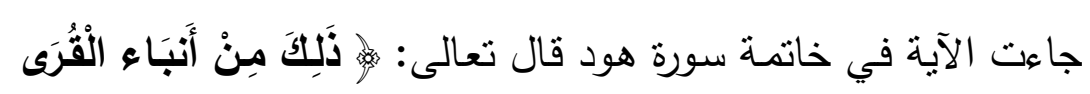

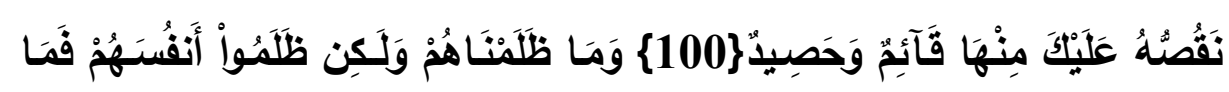

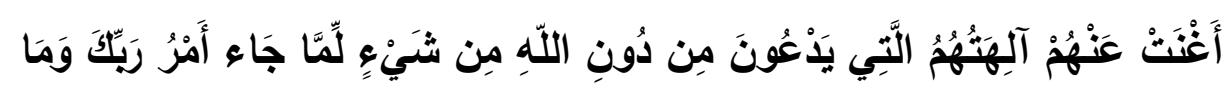

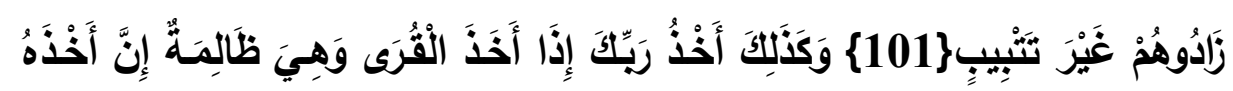

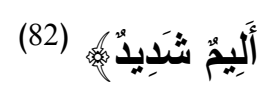
تضـمنت آيـات سورة هود الستّابقة لهذه الآيـات قصصـاً مفصنّلاً بعض

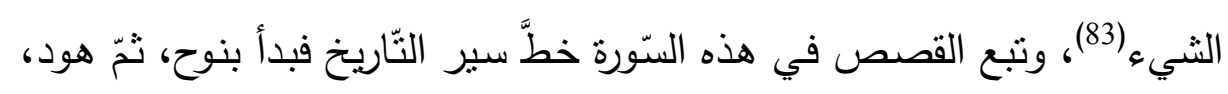
ثمّ صالح، ولمَّ بطرفٍ من قصّّة إبراهيم في الطريق إلى لوط، ثمّ شعيب ثمّ إثـارة إلى موسى؛ ليذكّر التالين بمصير السالفين على التوالي بهذا الترتيب الستّابق، 


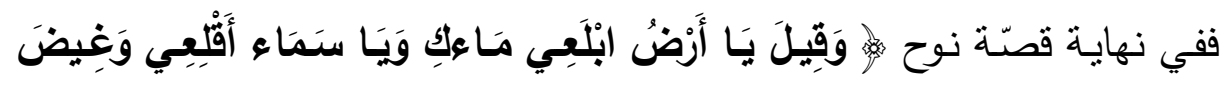

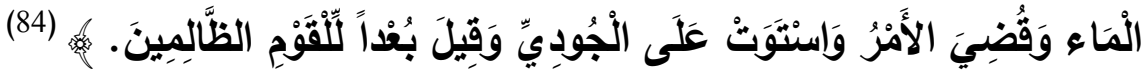

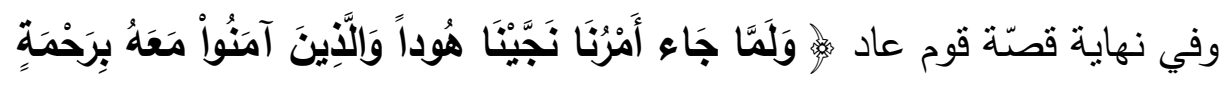

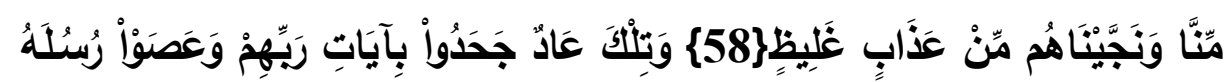

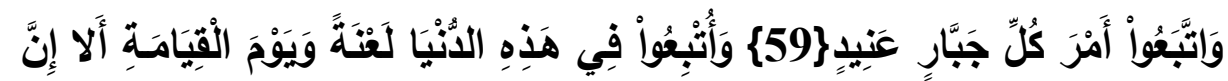

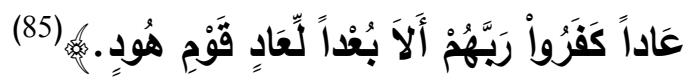
إلـى آخـر القصـص فـي سـورة هـود حيـث مصــارع القوم معروضــة، ومشاهدهم تزحم النفس والخيال، منهم الغارقون في لُجّة الطّوفان الغامر ، ومنهح المأخوذون بالعاصفة المدمّرة، ومنهم من أخذته الصّيحة، ومنهم من خسفت بـه وبداره الأرض، ومنهم من يقدم قومه يوم القيامه فأوردهم النار، وما حلّ بهم من قبـلُ في الدّنيا يخايـل للأنظـار في هذا الموضـع، وقد بلـن السّياق مـن القلوب

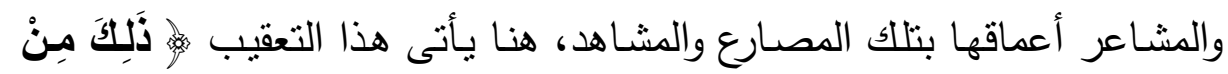

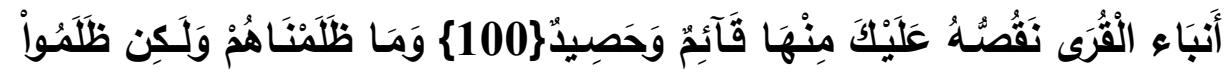

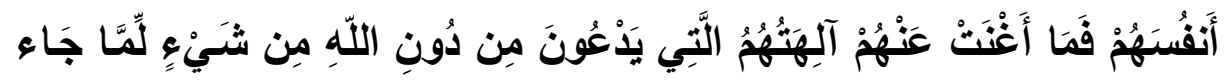

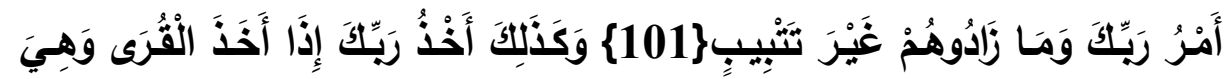

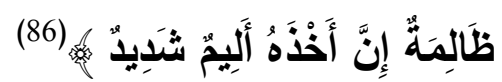
كذلك الذى قصصناه عليك، وبمثل هذا الذّمار والنّال يُأْخُذُ ريُّك القرى

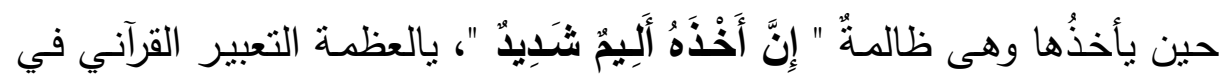
تعبيره عن هـلاك الظالمين السّابقين بالمصدر الصَّريح " أَخْذ"؛؛ لنشـعر معه أنّ أَخْذَ الظالمين واقعُ لا محالةَ، لا احتماليّةَ فيه، ولا يرجى الخلاص منه، ولا مكان 


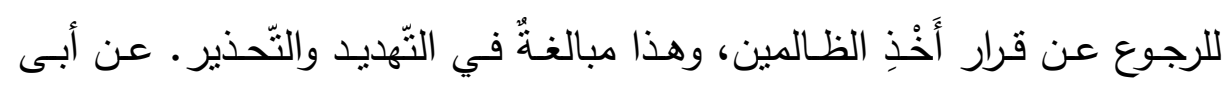
موسى الأثعري قال:" قال رسول الله - صـلّى الله عليه وسلّم: إنّ الله سبحانه

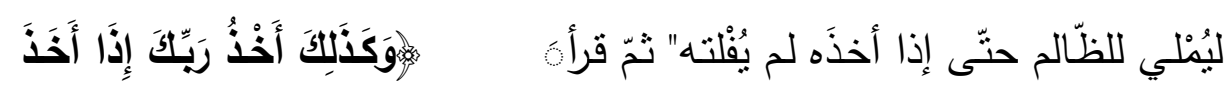

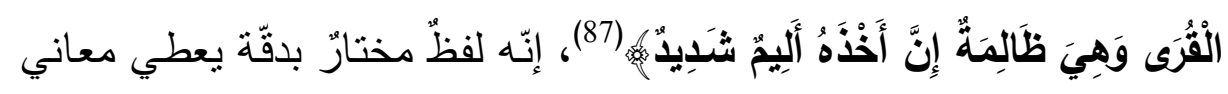
بقاء الوعيد واستمراره في الزمان كلّما ساد الظّلم في الأمم وسيطر الظّالمون، إنّها تلاقي مصيرها الذى يقدره الله لها، وفْقُ سنتِه التىى لا تختلف على مدار الزمان، فهو منلّ حئٌ لكلّ ظالٍ "وتختلف قوّة الأخْذِ بقوّة الآخذ، فإذا كان الآخذ هو الله سبحانه فهو أخْذُ عزيز مقتدر ."(88) وهذا ما شاهدنا بأبصارنا في عصرنا الحديث حيث ساد الظلّم وسيطر الظّالمون، فأخذ اله الظّالمين بظلمهم.

$$
\text { أنْ أسأل - سوأل }
$$

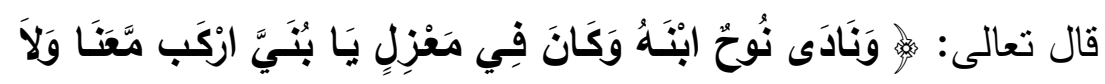

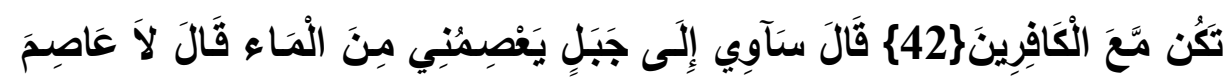

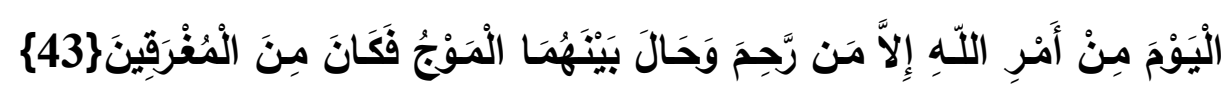

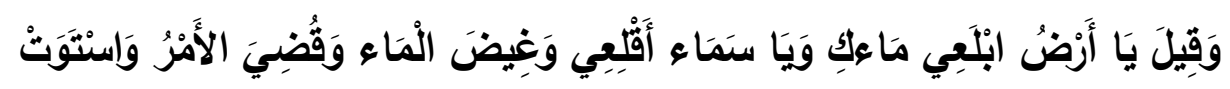

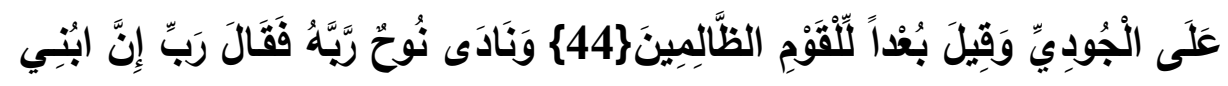

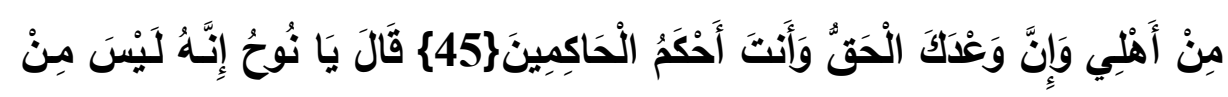

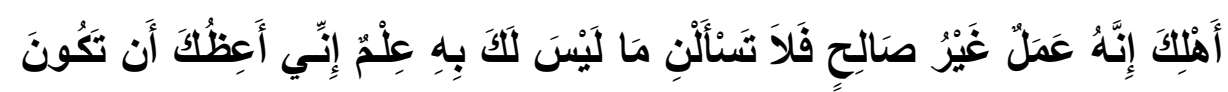

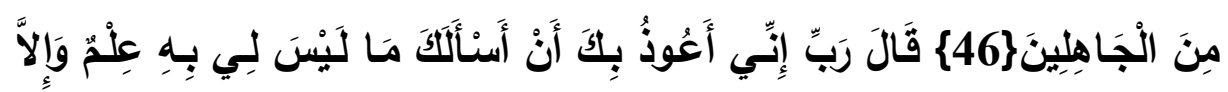

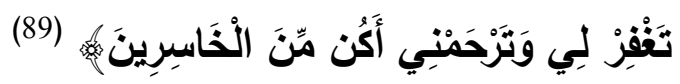


يقتضى السيّاق (90) أنّ نداء نوحٍ - عليه السّام - ربَّه كان بعد استواء السيّفينة على الجودي نداءً دعاه إليه داعي الثّفقة، فأراد بـه نفع ابنه في الآخره

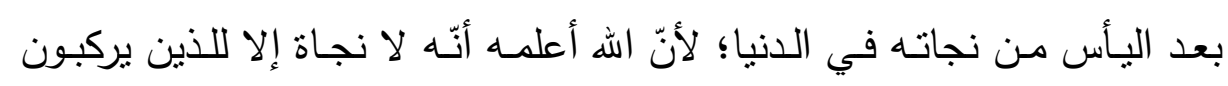
الستّفينة. والنّداءُ هنـا نداءُ دعاء فكأنّه قيل: ودعا نوحُ ربَّه؛ لأنّ الدعاء يصدر

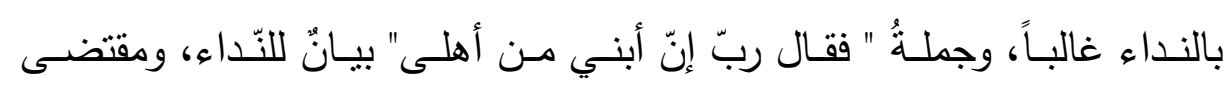

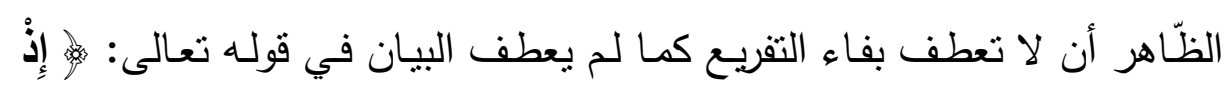

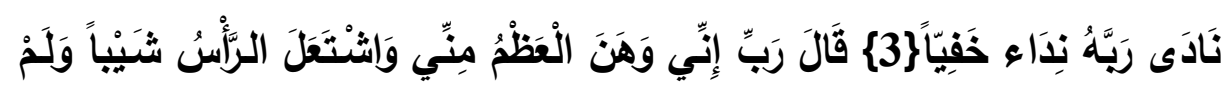

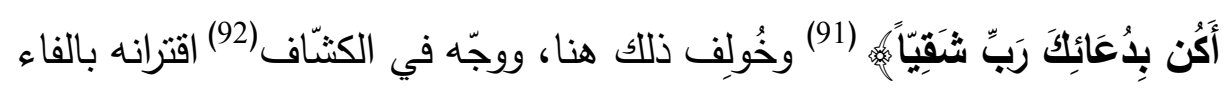

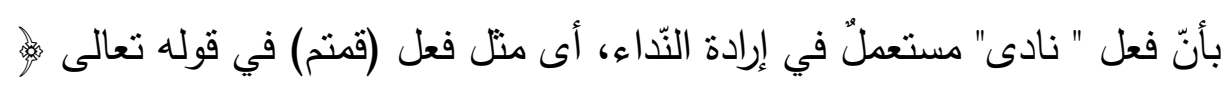

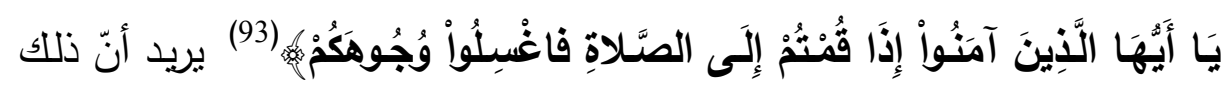
إخراجُ (94) للكلام على خلاف مقتضى الظّاهر فإنّ وجود الفاء في الجملة التى هى بيانٌ للنداء قرينة على أن فعل "نادى" مستعار لهنىى إرادة النّداء، أى: أراد نداء ربّه فأعقب إرادته بإصدار النّداء، وهذا إثـارة إلى أنّه أراد النّداء فتردّد في إن

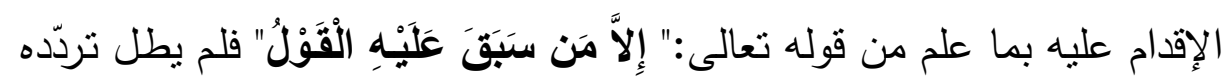
لما غلبته الثَّقة على ابنه فأقدم على نداء ربّه، ولذلك قدم الاعتذار بقوله:" إنَّ

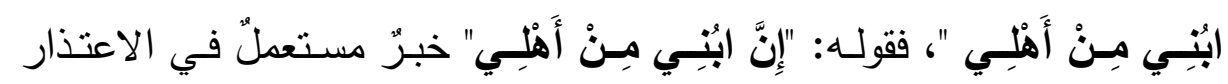

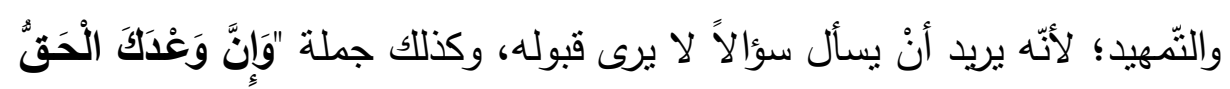

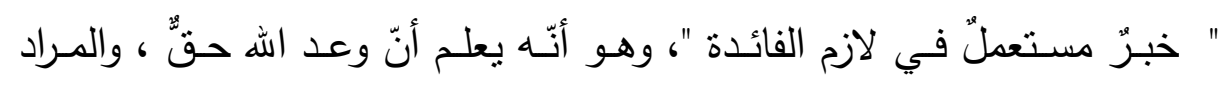

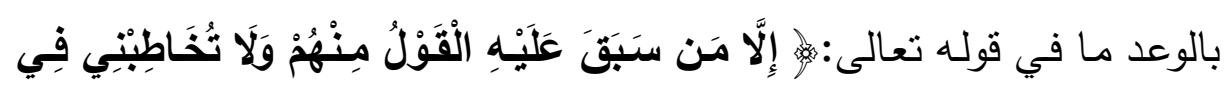

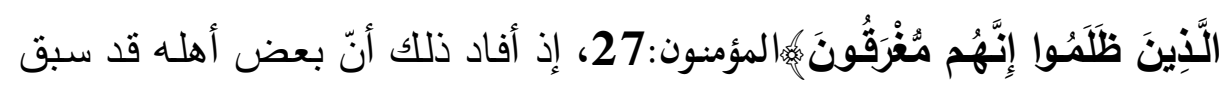


من الله تقديرُ بأنّه لا يركب الستّفينة، وهذا الموصول "مَنْ" متعيّن لكونه صـادقاً

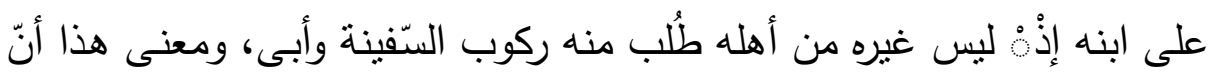

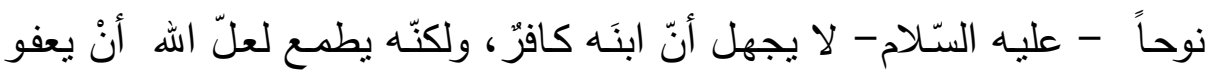

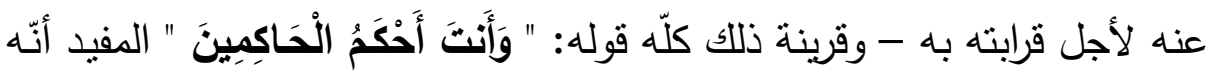

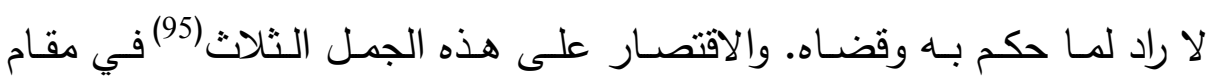

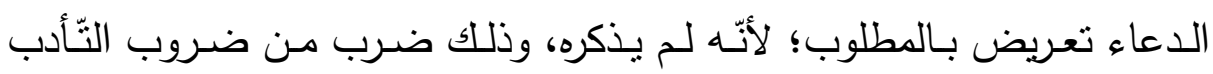

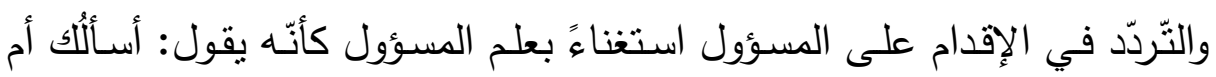

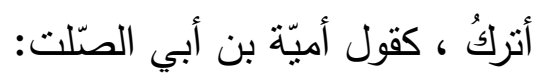

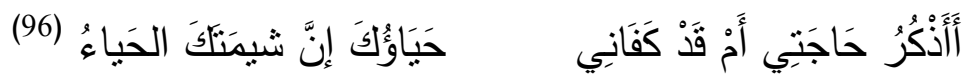

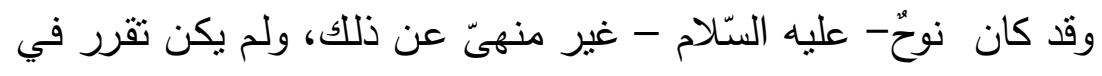

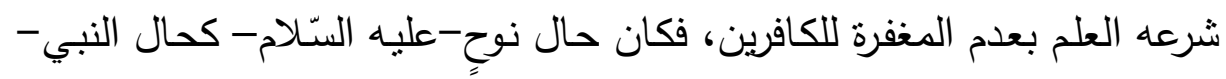

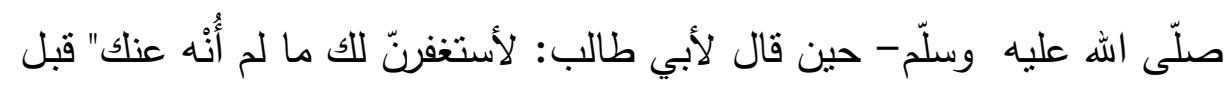
(97) أنْ ينزل قول نعالى

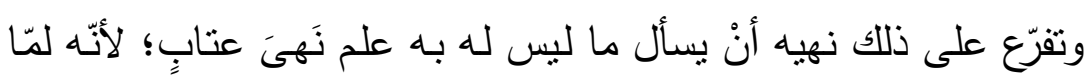

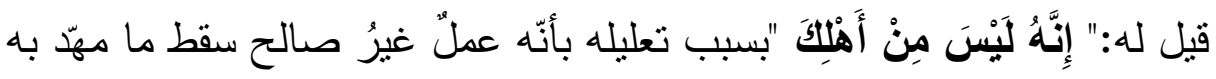
لإجابة سؤاله، فكان حقيقاً بأنْ لا يسأله وأنْ يندبّر ما أراد أنْ يسأله من الله.

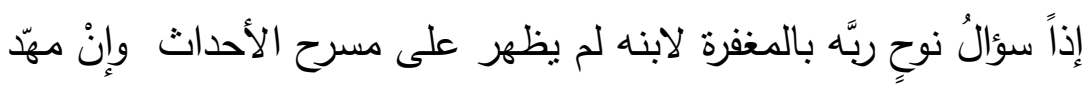
له نوحٌ بالجمل الثلاث لاختبار حال إقبال الهه على سؤاله، فكان قوله نعالى : "فَلَاً

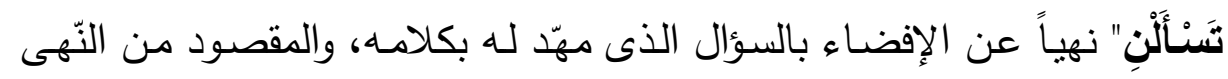

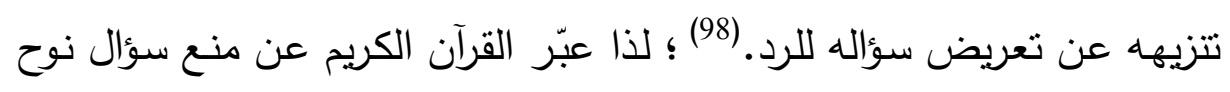


من الظهور خارج قلبه إلى مسرح الأحداث وكتمانه مسلّماً بما أمر الله بالمصدر

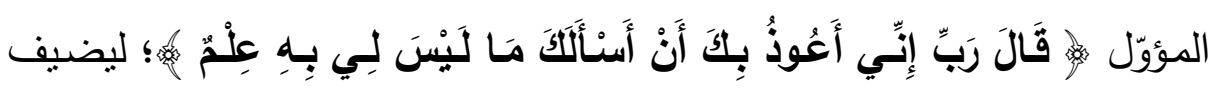

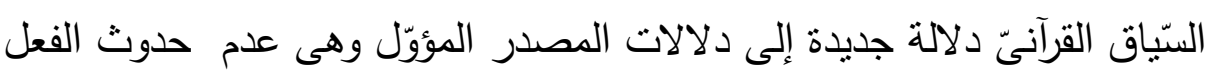

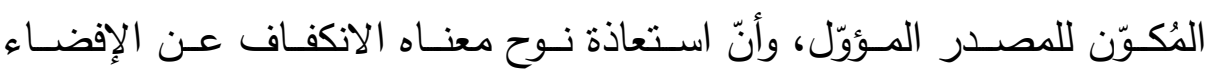

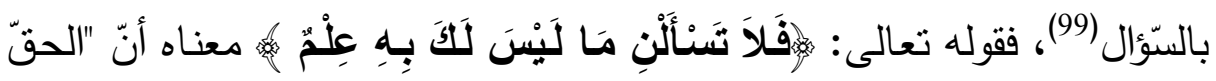
سبحانه يطلب من نوحٍ هنا أنْ يفكّر جيّداً قبل أنْ بسأل، فلا غبار على الأنبياء

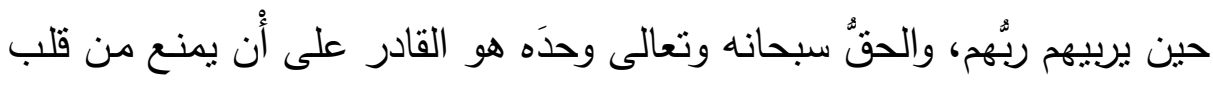

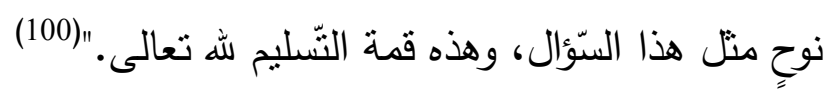
ولنتناول آية أخرى تقارن فيها بين دلالة المصدر المؤوّل"أنْ أسئلَ"الذى لهى

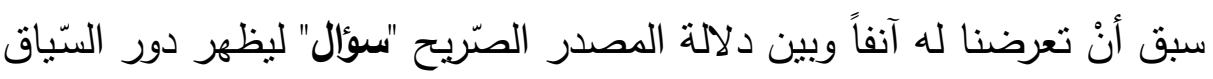

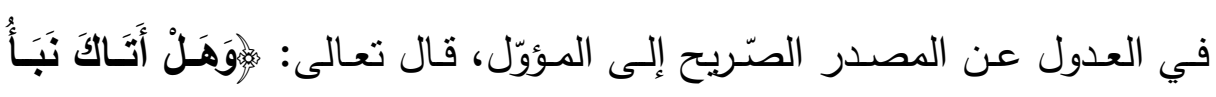

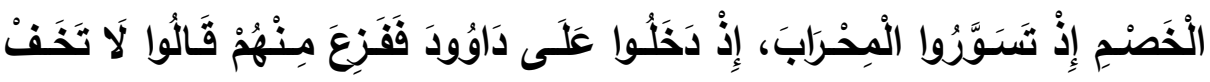

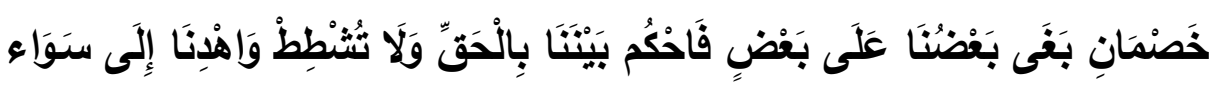

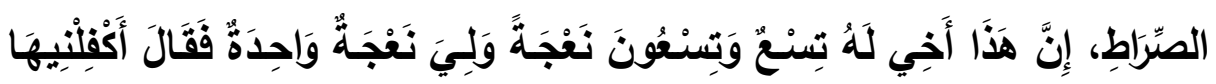

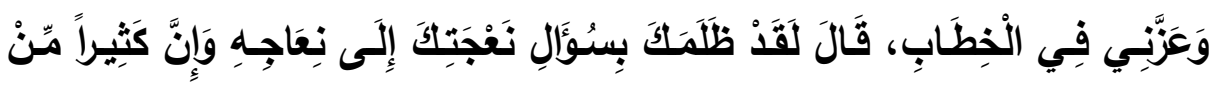

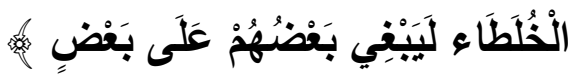

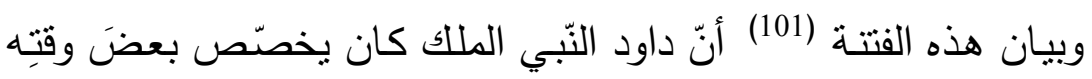

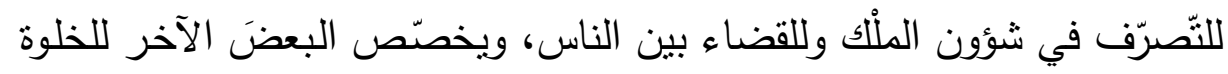

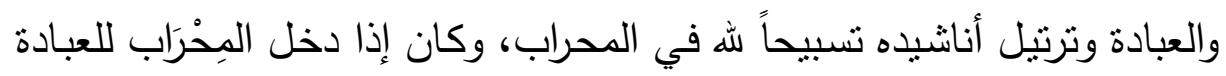

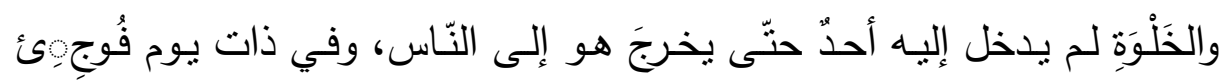


بشخصين يتسورَان المِحْرَاب المغلق عليه، فقزع منهما، فما ينسور المِحْرَاب هكذا

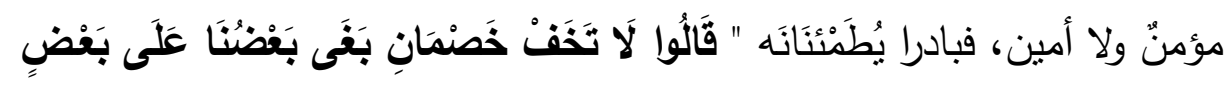

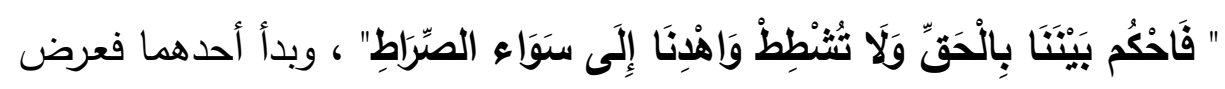

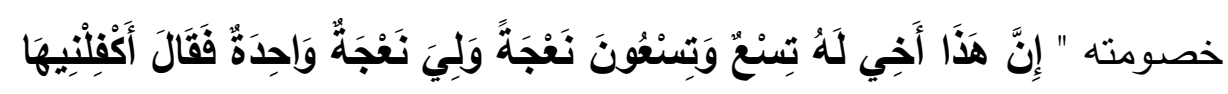

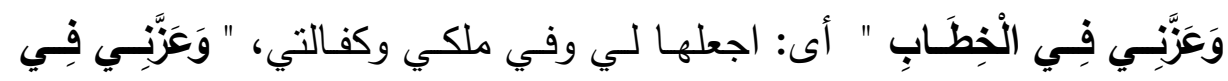
الْخِطَبِ " أبي: شدّد عليّ في القول وأغلظ . والقضيّة - كما عرضها أحد الخصمين - تحملُ ظلماً صسارخاً مثيراً لا يحتمـل التأويـل، ومـن ثمّ اندفع داود يقضـي على إثر سـماعه لهذهـ المظلمــة الصّّارخة، ولم يوجّه إلى الخصم الأخر حديثاً، ولم بطلب إليه بياناً، ولم يسمع له له حجة، ولكنّه مضى يحكم: " قال لقد ظلمك بسؤال نعجتلك إلى نعاجه، وإِّ كثيراً مـن الخلطساء (أي الأقويـاء المخـالطين بعضـهم لبعضٍ)- ليبغـى بعضـهم على بعضٍ إلا الذين آمنوا وعملوا الصّالحات وقليل ما هم." لقد ذكر القرآن الكريم قول أحد الخصمين " أَكَفْلْنِيهَا وَعَزَّنِي فِي الْنِطَابِ " أي: اجعلها لي، وفي ملكي وكفالتي، وشدّد عليّ في القول وأغلظ؛ لذا عبّر بما

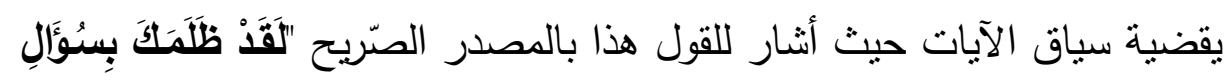

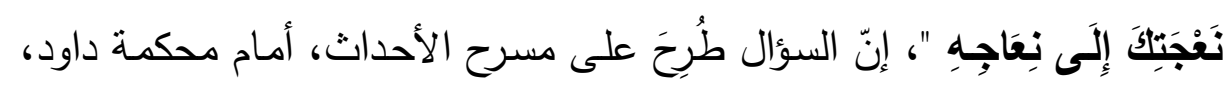
وكان فيه غلظة وشدّة فما كان من داود إلا أنْ عبّر بالمصدر الصّربح ليشعر معه القارئ أنّ أحد الخصمين قد سأل خصمه أنْ يعطيه نعجته، ولمّا رأى منـه تمنّعاً اشتدّ عليه بالكلام وهدده. وبتجاور الآيتين يظهر الفارق الدلاليّ الذى أشرنا

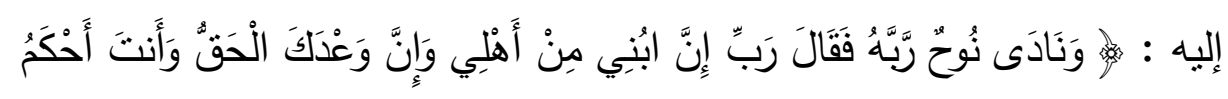




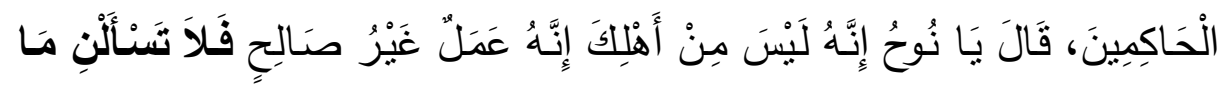

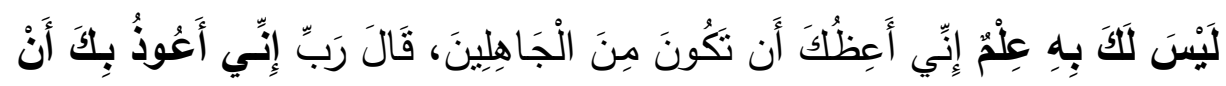

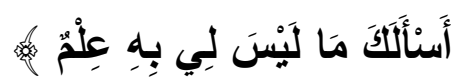

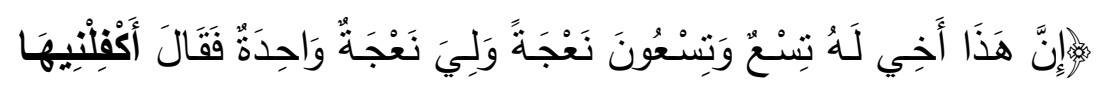

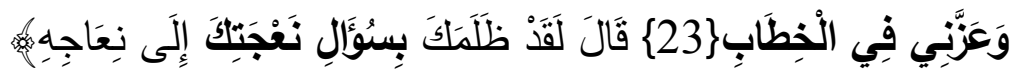

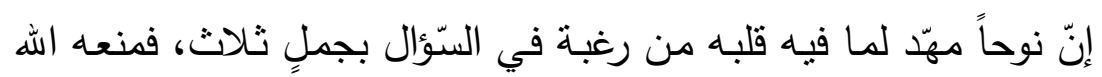

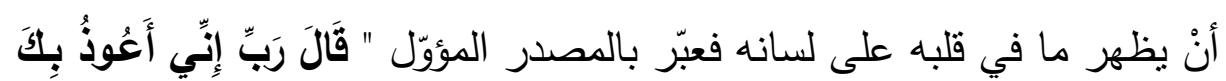

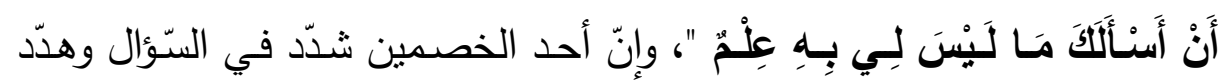

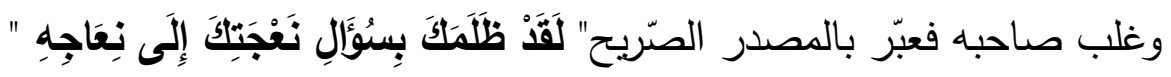

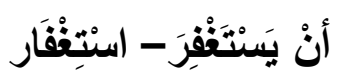

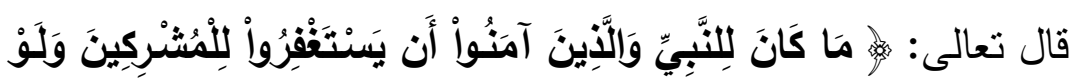

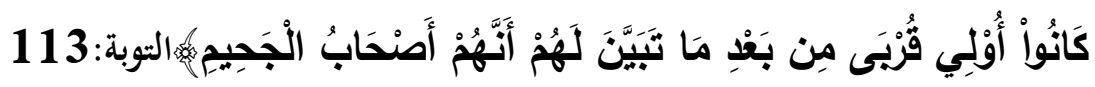

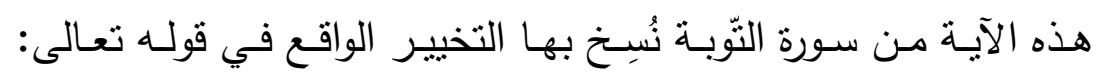

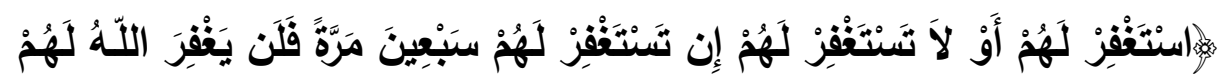

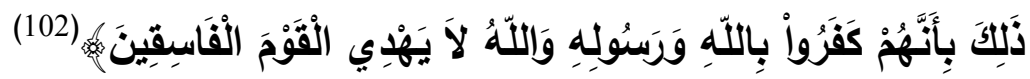
وجاءت هذه الآية عقب عرض نماذج من المنافقين وأحوالهم وأقوالهم

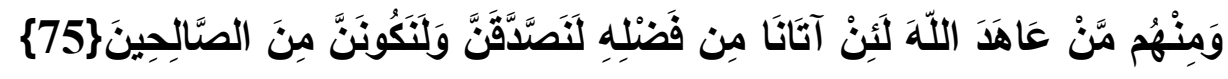

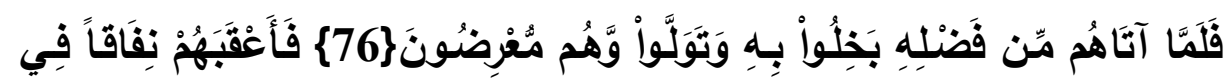

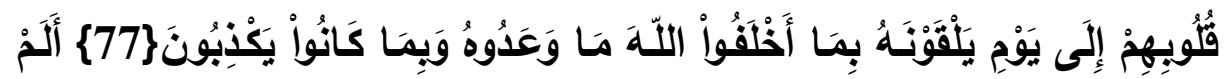

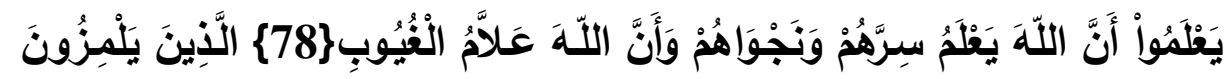




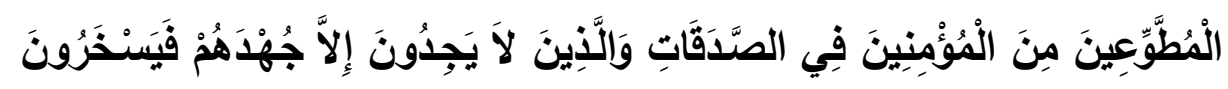

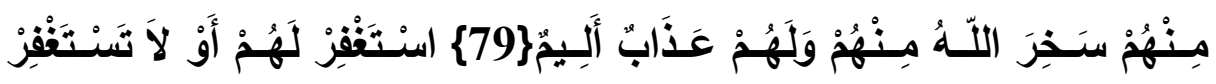
(103)

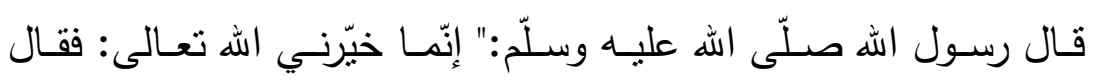

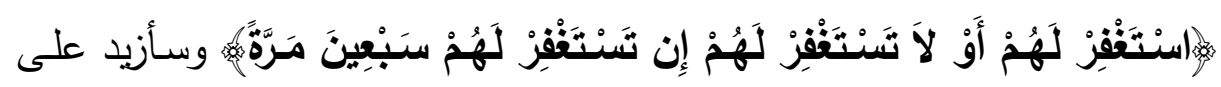
سبعين." (104)

والذى يظهر أنّ رسول الهه - صلّى اله عليه وسلّم - لكّا أوحي إليه بآية

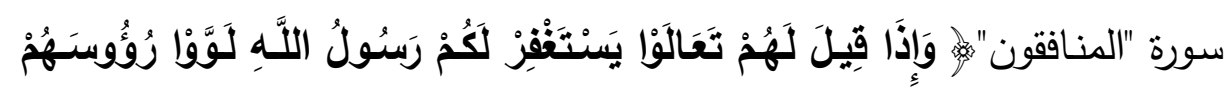

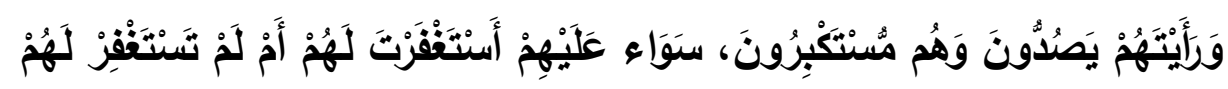

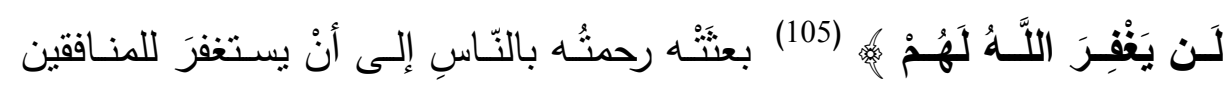

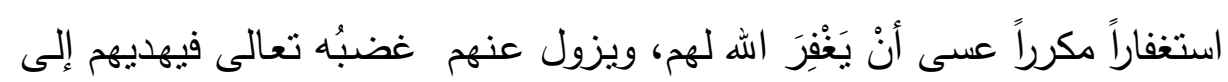

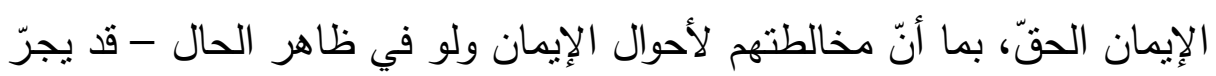

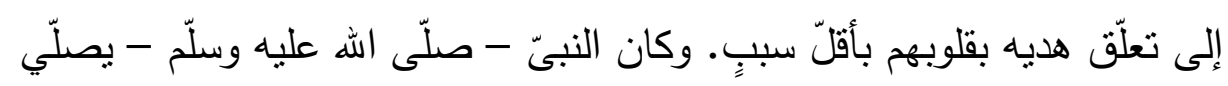

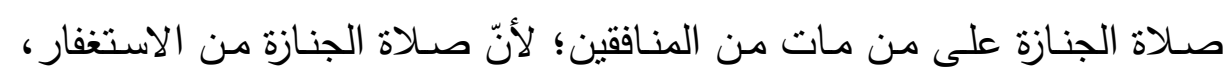

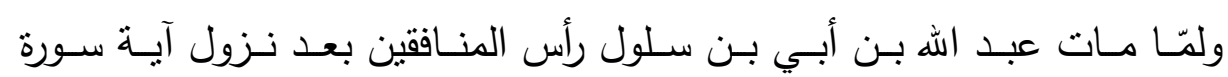

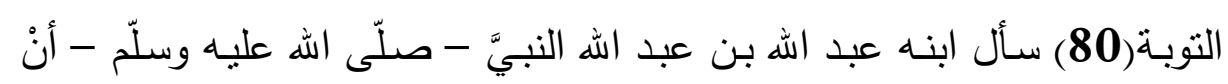

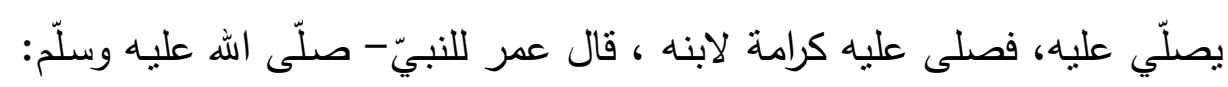

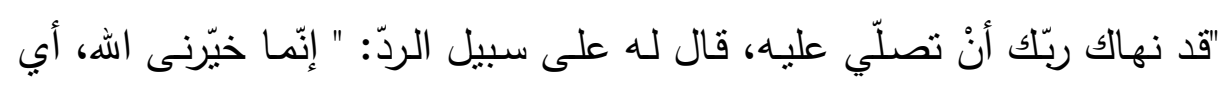
ليس في هذه الآية نهي عن الاستخفار ، فكان لصلاته عليهم واستخفاره لهم حكمة لهم

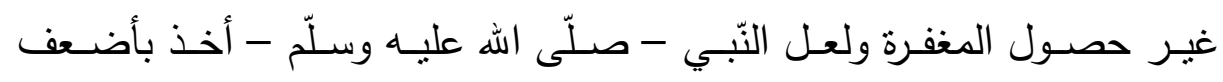


الاحتمالين في صيغة(استخفر لهم أو لا تستغفر لهم )، وكذلك في لفظة عدد سبعين مرّة استقصاءً لمظنّة الرّحمة (106)، ثمّ أراد الله نسخ ذللك على سبيل التّدرّج على عادة التشريع في غالب الأحوال، ولعل الغرض الذى لأجله أبقى التخيير في الاستغفار لهم قد ضعف ما فيه من المصلحة، فنهى الله النبََّ -صلّى الله عليه وسـلّم - والمؤمنين معـاً عن الاستتفار للمشـركين بعد أنّ رخّص للنبـيّ-ـ صلّى الله عليه وسلّم - خاصّة في قوله:" استغفر لهم أو لا تستغفر لهم." (107)

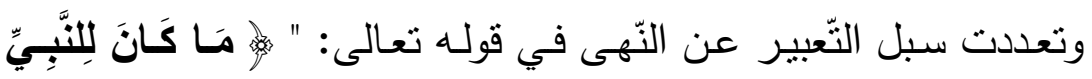

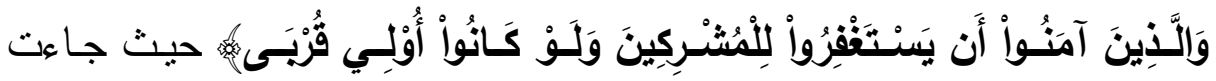

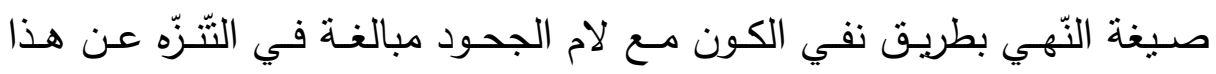
الاستغفار ثُّ عبّر بالمصدر المؤوّل " أَن يَنْنَفْفْرُواْ " ليعطي دلالة انتفاء الحدث من قلوب النّبي والمؤمنين، وأنّ ما كان مرخّصاً صسار منهيّاً عنه، وزاد" وَلََوْ كَانُواُ أُؤلِي قُرْبَى " للمبالغة في استقصاء أقرب الأحوال إلى المقدرة، ثمّ عقّب بمصدرٍ صـريحٍ "استغفار" يماثل لغويّاً المصدر المؤوّل السـابق " أنْ يستغفر"، ولكنّه لا

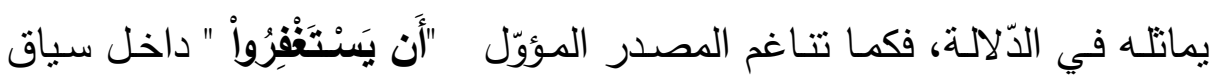
الآيـة لإظهار المبالغة في النّهى عن الاستخفار، جاء المصدر الصّربح

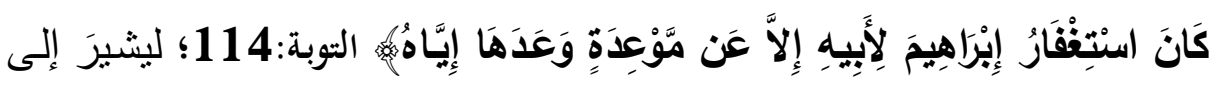
أنّ إبراهيم قد استغفر لأبيه بالفعل، وأنّ الاستغفار قد وقع، وذكر ذلك في القرآن

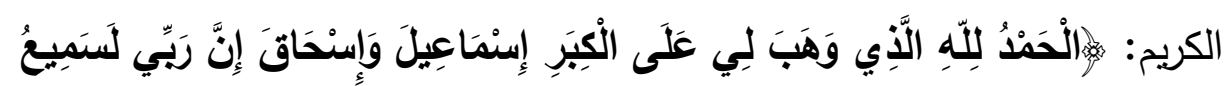

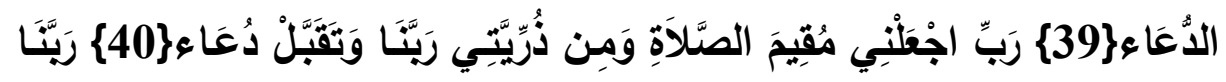




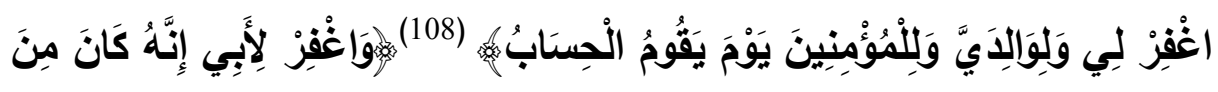
الضَّالِّينَ (109)

إنّ استغفارَ إبراهيم لأبيـه كان بسبب وعده لـه أنْ يستغفر لـه اله لعلّهـ

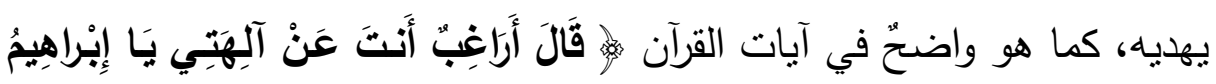

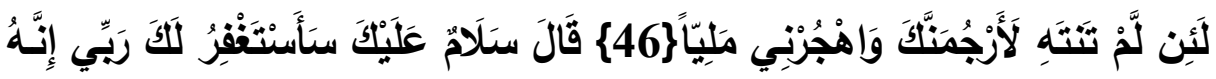

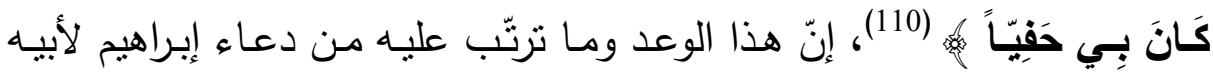

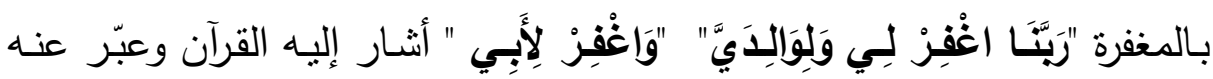
بالمصدر الصتريح الذى يعطينا دلالة قاطعة على وقوع الحدث وأنّه لا احتماليّة

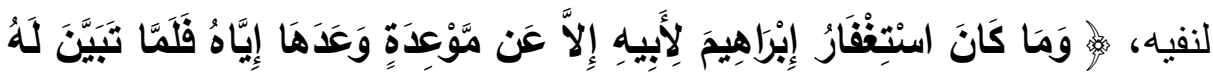

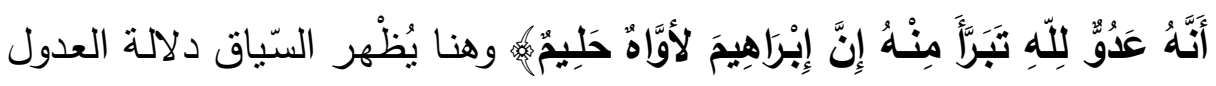
عن الصددر الصّريح إلى المؤول في آيتين متتاليتين من سورة التُّبة. 


$$
\text { أنْ تعدلوا - العدل }
$$

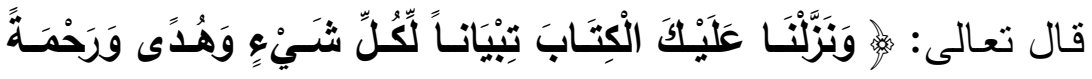

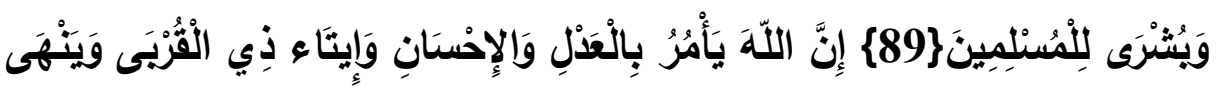

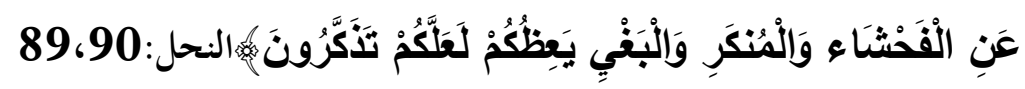
لمّا جاء أنّ هذا القرآن تبيانٌ لكلّ شيء وهدى ورحمة وبشرى للمسلمين، حَسُنَ التّخلّصص إلى تبيان أصول الهدى في التشريع للدين الإسـاميّ العائدة إلى

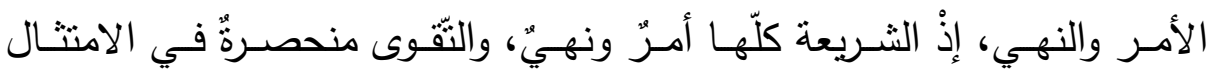
والاجتتاب، فهذه الآيـة جامعةُّ أصولَ النتريع(111)؛ لأنّ هذا الكتاب جاء لينثِئ أمّة وينظّم مجتمعاً، جاء دعوة عالميّة إنسانيّة لا تعصّب فيها لقبيلة، أو أمّة، أو جنس، إنّمـا العقيدة وحدَها هـى الآصـرة، والرابطة، والقوميّة والعصبيّة، ومن ثمّ جاء بالمبادئ التي تكْفُلُ تماسك الجماعة والجماعات، جاء " بِالْعَدْلِ " الذَى يكَفُلُ لكلّ فردٍ، ولكلّ جماعـة ولكلّ قومِ قاعدة ثابتة للتّعامل لا تميل مـع الهوى، ولا

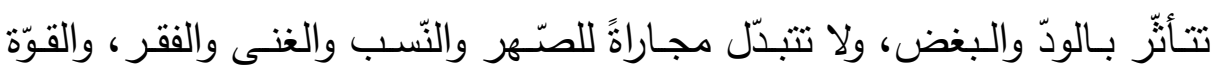
والضّعف ، إنّما تمضي في طريقها تكيل بمكيالٍ واحدٍ للجميع، وتتن بميزانٍ واحدٍ للجميـع(112). إنّ الآيــة الجامعـة لأصــول التشـريع ومبـادئ تماســك الجماعـة ومعاملتهم بقواعد ثابتة يناسبها التعبير بالمصدر الصّربح " العَدْل " المتتاغم مـع معطيات السّياق القرآنيّ، حيث افتتاح الجملة بحرفِ التوكيد للاهتمام بشأن مـا حوته، وتصديرها باسم الجلالة للتشربف، وذكر " يَأْمُرُ " و "يَتْهَى" للتشويق، وعبّر بالمصدر الصّرِح " العَدْل - الإحسان - إيتاء"؛ ليناسب حالة إقرار قواعد النّشريع 
الثَّابتة الجامعة، قال ابن مسعود لمّا نزلت هذه الآيـة:"أجمعُ آيات القرآن للخير هذه الآية(113)؛ لأنّها جمعت كلّ الفضائل التى يمكن أنْ نكون في القرآن الكريم.

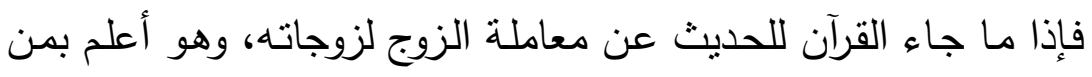

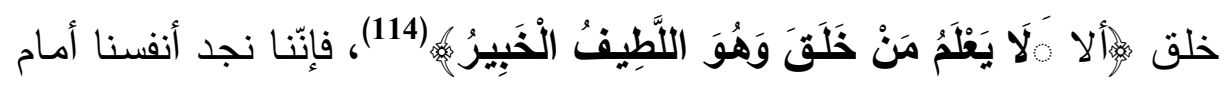

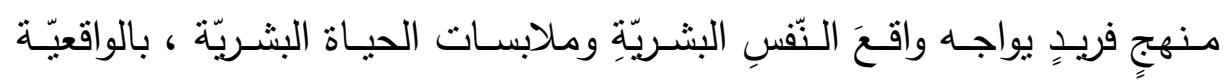

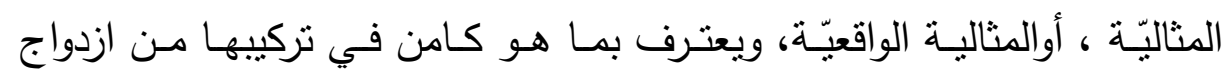

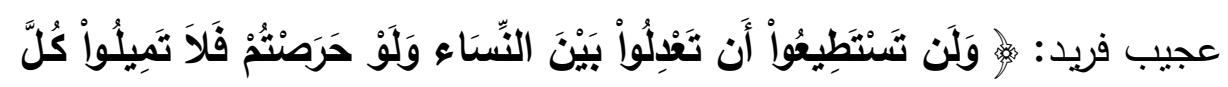

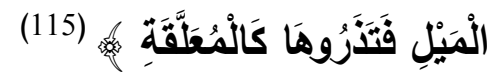
لقد عدل القرآن عن التُّبير بالدصدر الصّريح إلى المصدر المؤوّل؛

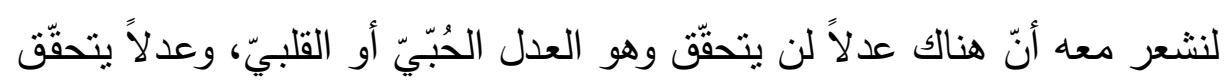

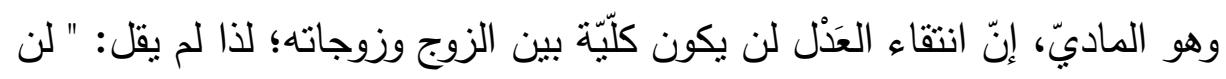
تسنطيعوا العَدْل بين النّساء "، فاله الذى فطر النفس البشريّة يعلم من فطرتها

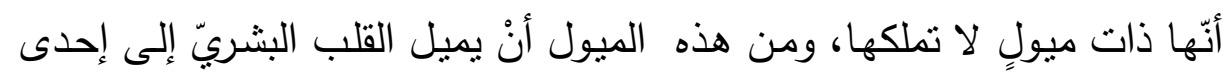

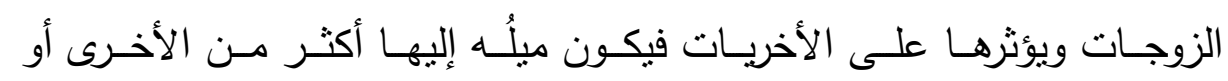

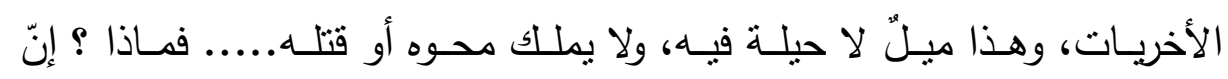

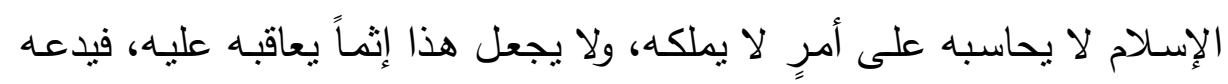

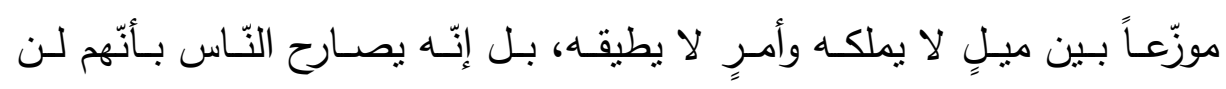

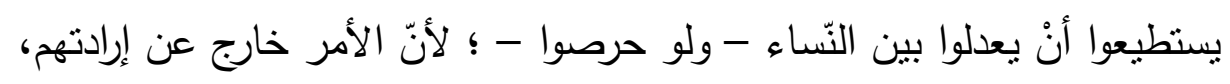

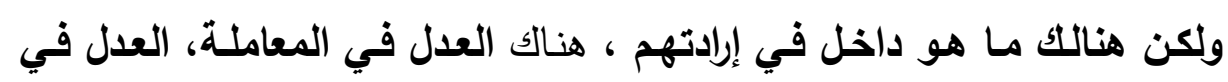

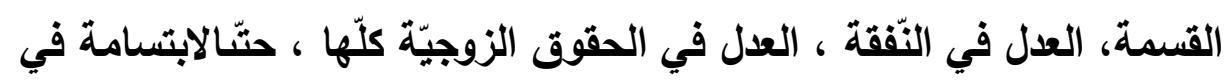


الوجه، وإلكلمة الطيبة باللسـان ، هذا مـا هم مطالبون بـه(116) إن دقة التعبير القرآنى لَتبُّهر العقول وتأخذ بنواصي القلوب حين يعبّر عما هو ثابتُ ومقررٌ من

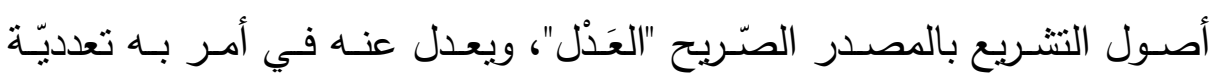
واحتماليّة التّحقّق في معاملة الزوج لزوجاته، فنفْيُ الاستطاعة بين النّساء ليس

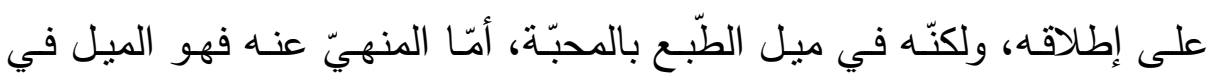
المعاملـة الظّّاهرة، وكان رسـول اله - صـلّى الله عليهـ وسـلّم - وهو يقسّم بين نسائهِ فيما بملك ويعدل في هذه القسمة لا ينكرُ أنّه يؤْنز بعضهن على بعض، لَّل وأنّ هذا خـارجّ عمّا يملك، فكان يقول:--صلّى الله عليه وسـلّم -: "اللهمّ هذا قَسْمي فيما أملاك فلا تَكُمني فيما تملِكُ ولا أملِكُ" (117)، وكان ذلك؛ لأنّ أمر النّساء

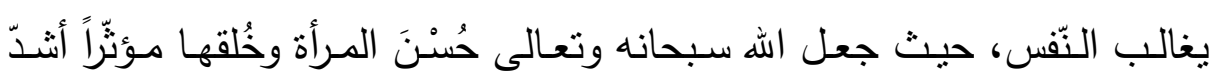

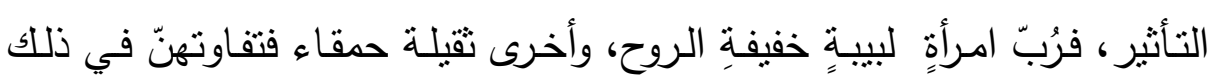
وخلوّ بعضهنّ منه يؤثٍّ لا محالةَ تفاوتاً في محبّة الزوج بعض أزواجه." (118) 


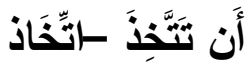

قال تعالى

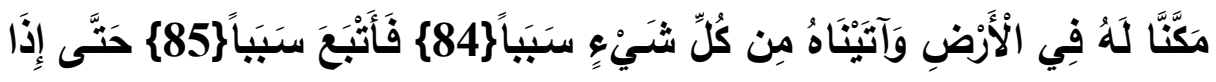

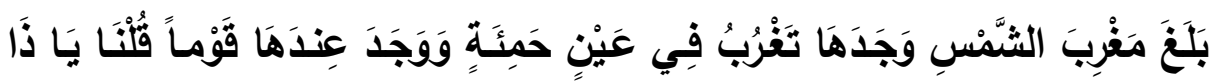

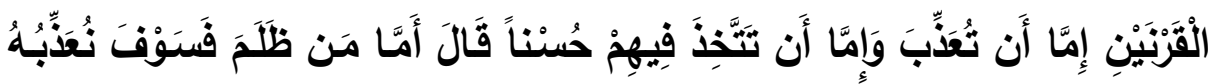

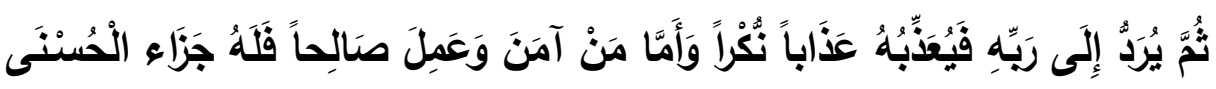

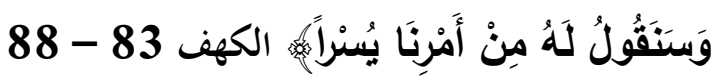

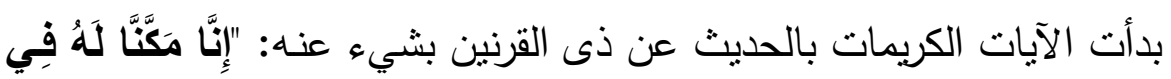

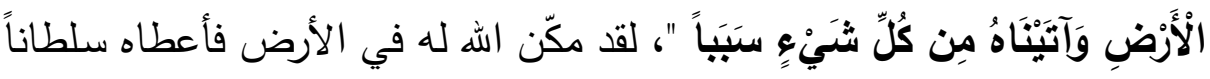

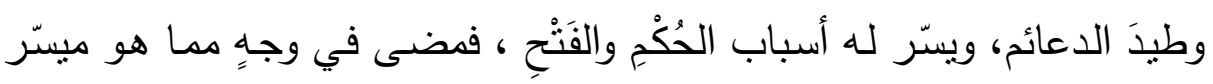

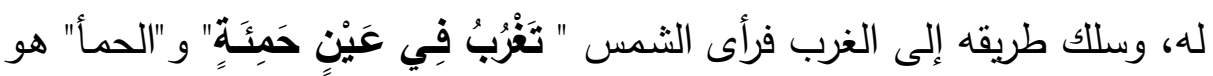

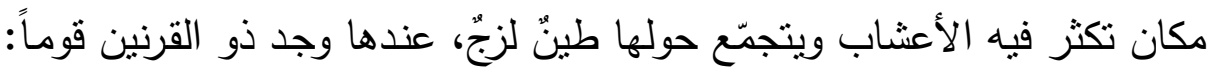

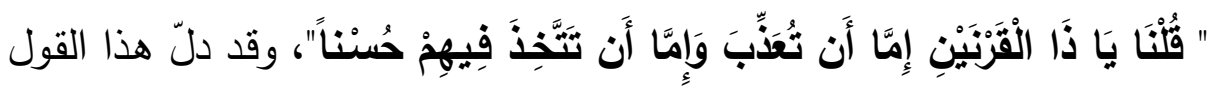

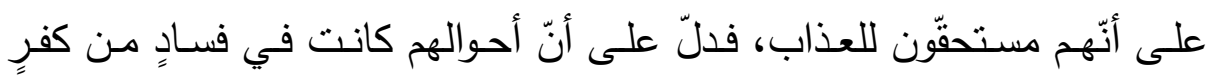

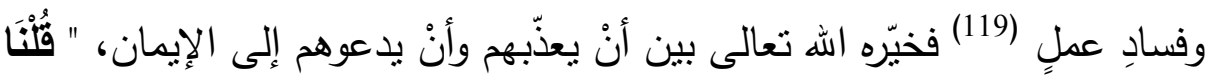

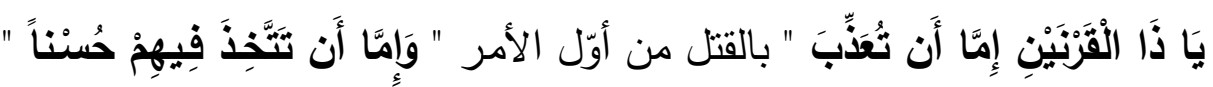
وذلك بالدعوة إلى الحقّ والإرشاد، حالة التخيير هذه ناسبها العدول عن المصدر

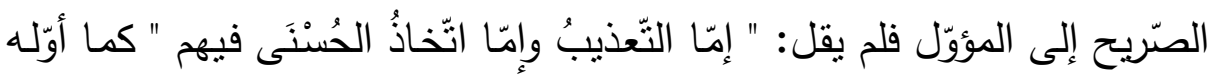

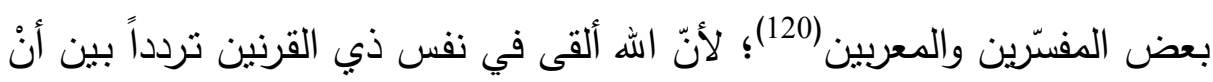
يبادر استئصالهم، وأنْ يمهلهم ويدعوهم إلى الإيمان وحُسن العمل، ويكون قوله:" 
قَالَ أَمَّا مَن ظَلَمَ " جواباً منه إلىى ربّه، أي: قال في نفسه معتدداً على حالةٍ وسط

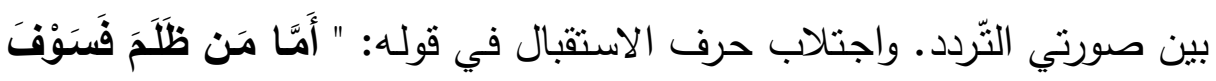

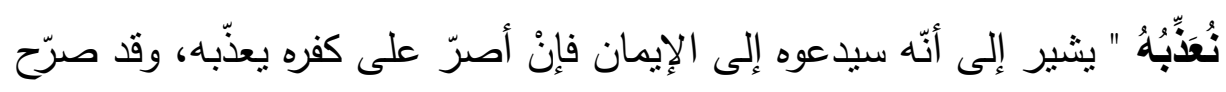

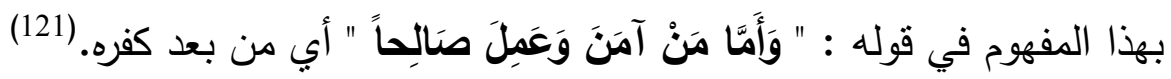

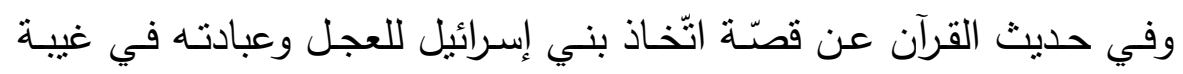

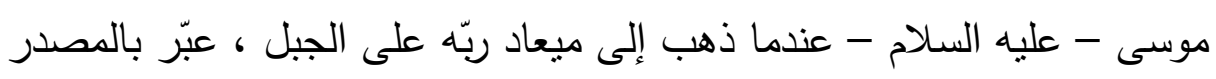

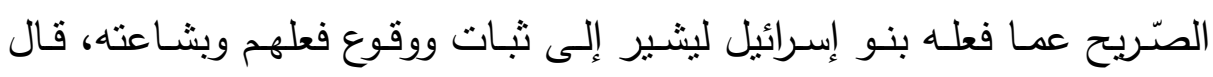

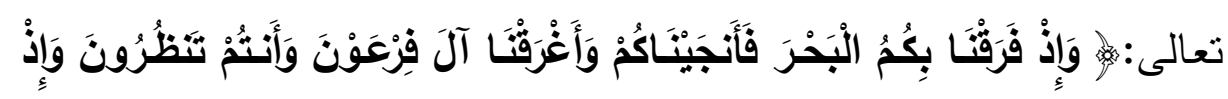

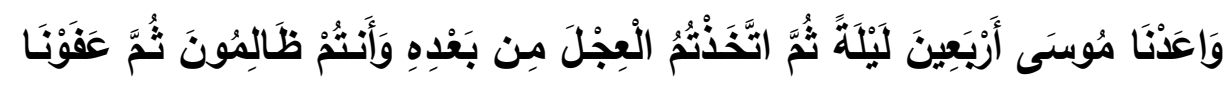

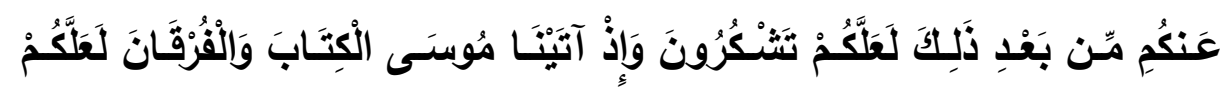

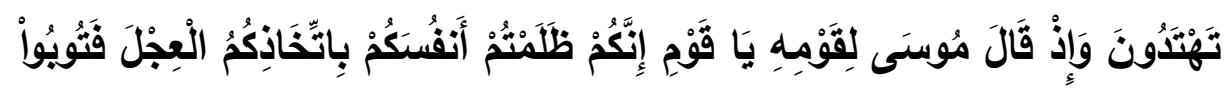

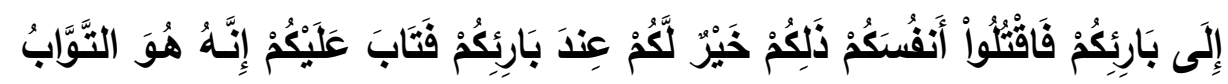

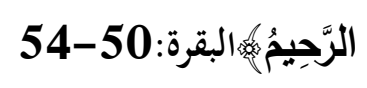

إنّ الله سبحانه وتعالى أراد أنْ يُحَحِص بنى إسرائيل ويبيّن لنا كفرهم

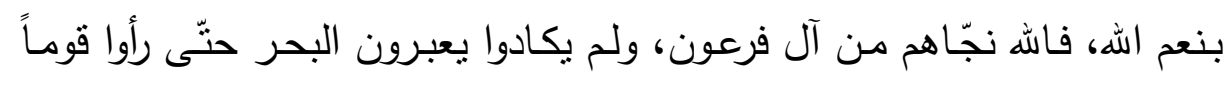

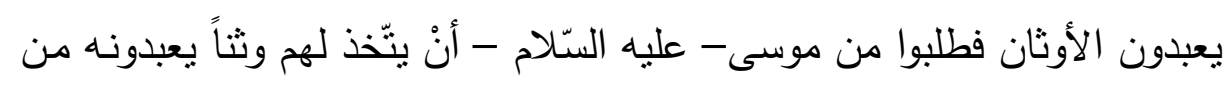

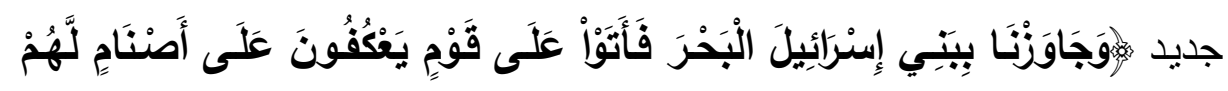

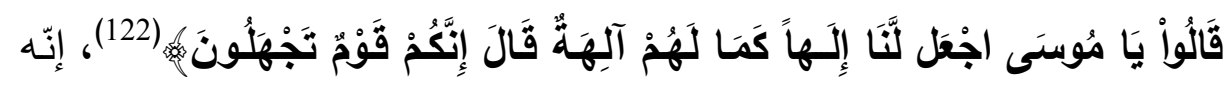

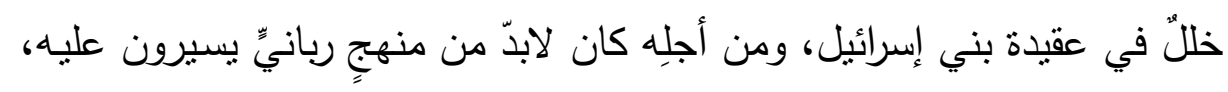

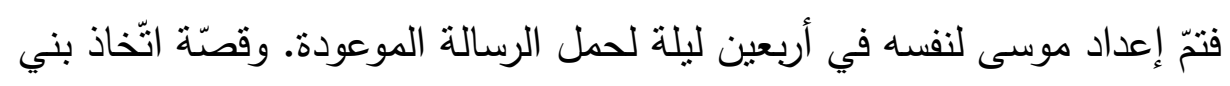

أ.د.إسلام عبد السلام

(تحولات المصادر في السياق القر آني دراسة دلالية.........) 
إسرائيل العجلَ وعبادته في غيبة موسى - عليه السـلام - مفصّلة في سورة طه

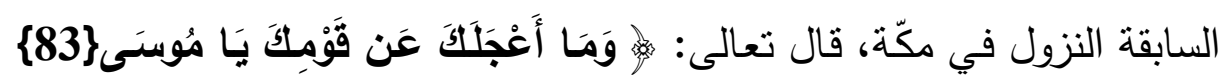

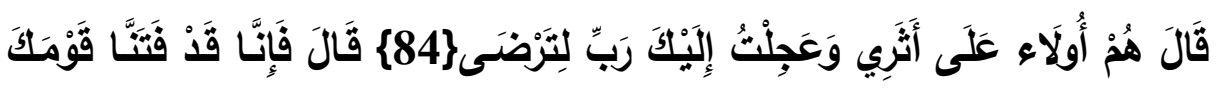

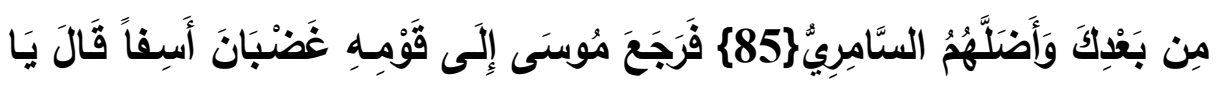

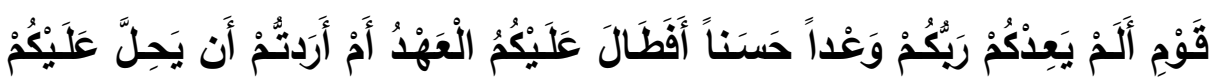

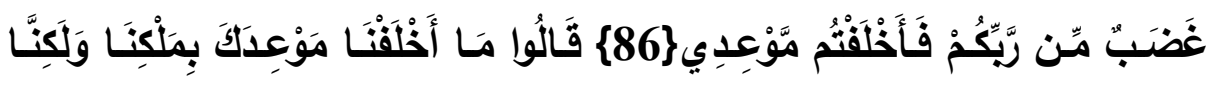

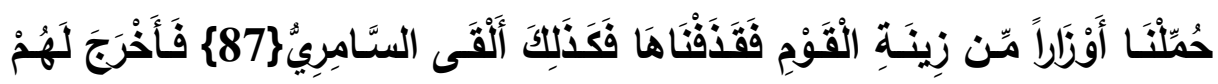

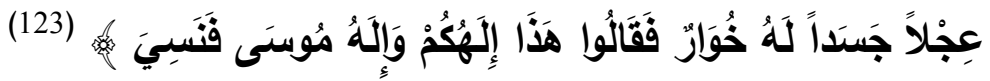

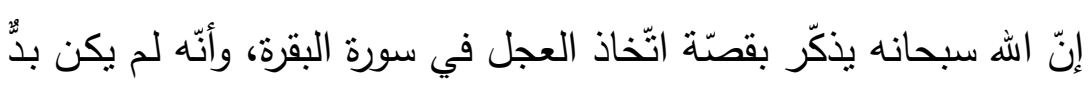

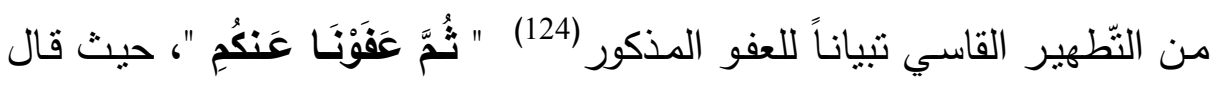

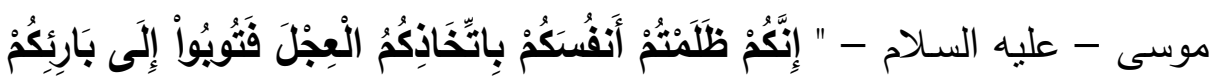

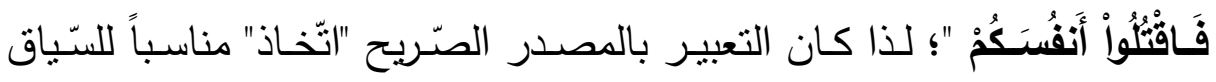
القرآنيّ الذى أشنار للقصّة في أكثر من موضع وفصّلها في سورة طه كما ذُكر آنفاً، فهو أمـرُ مقررٌ ثابتهُ مقطوعُ بحدوثه، وكمـا عبّر عنه في الآيـة الثالثة

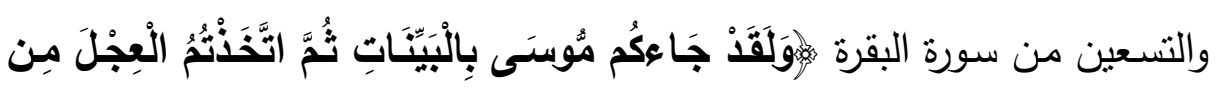

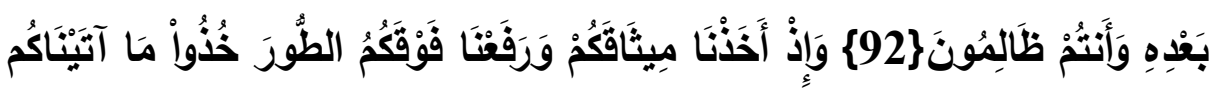

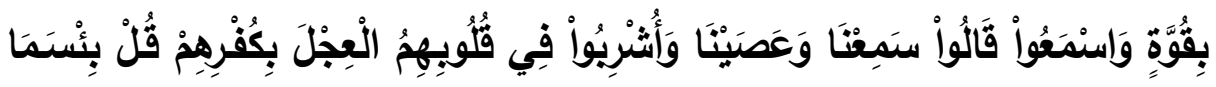

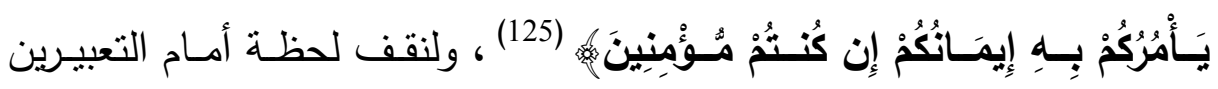

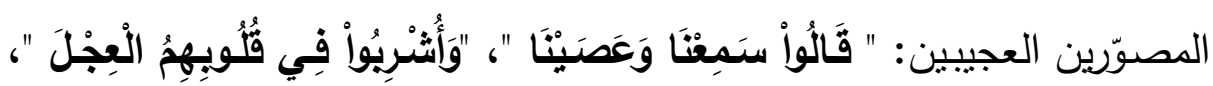
إنّهم قالوا سمعنا، ولم يقولوا عصينا، إنّه تصوير حيُّ للواقع الصّامت كأنّه واقعُ 
ناطق"، لقد قالوا بأفواههم سمعنا، وقالوا بأعمالهم عصينا ، وأمّا الصنّرة الغليظة

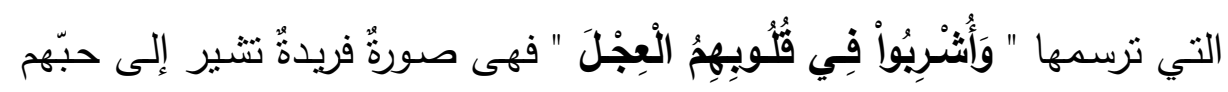

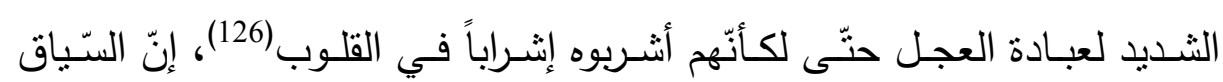

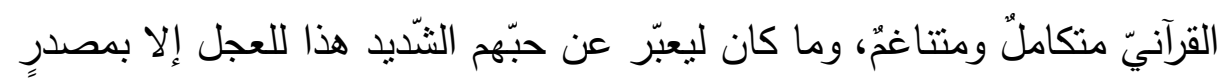

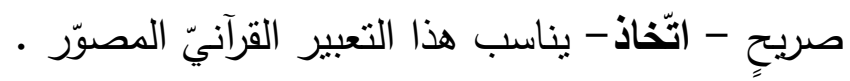
أنْ يفتنكم - فتنة

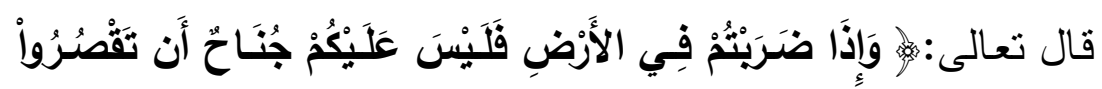

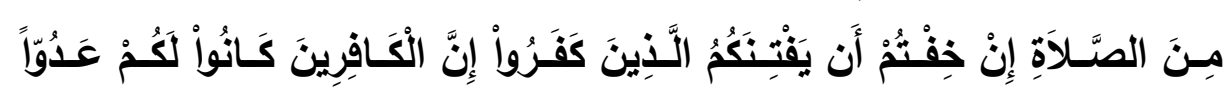
مُّبنِ

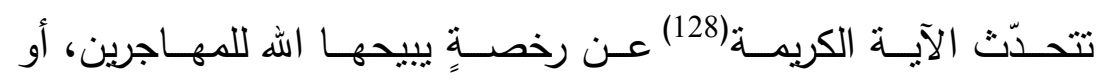

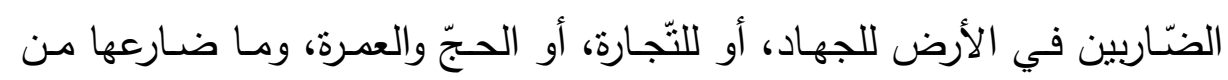

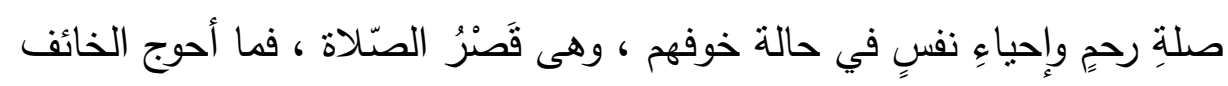

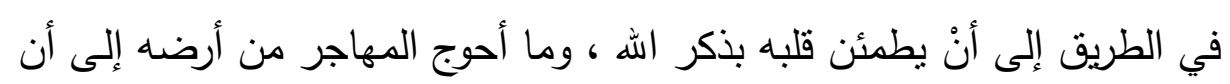

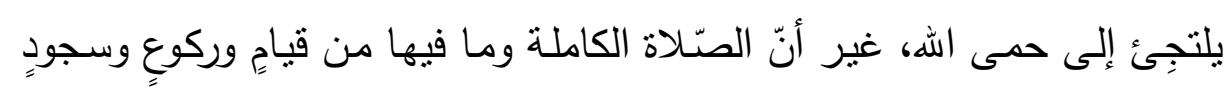

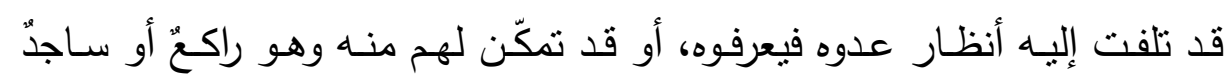

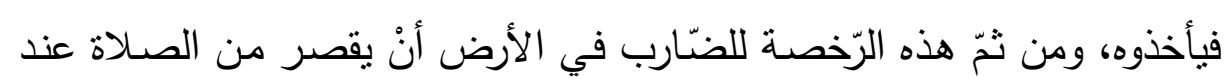
مخافة الفتنة.

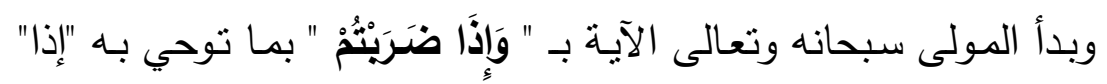
من أنّه لا غنى للمسلمين عن الضّترْب في الأرض لأسباب عدّه فـ "إذا" تدخل فئل

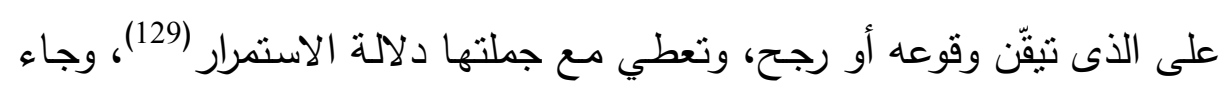




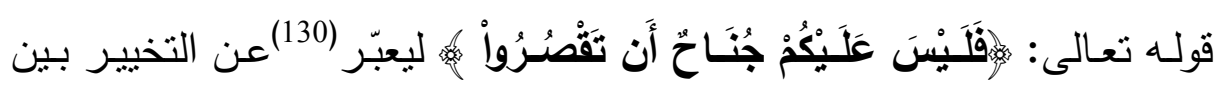

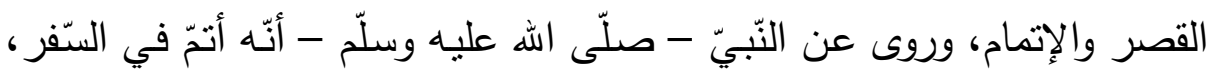

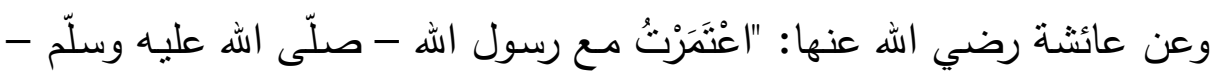

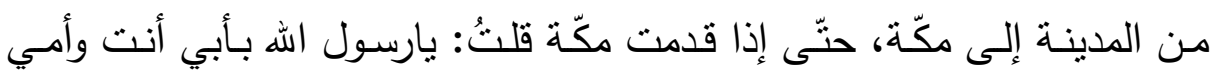

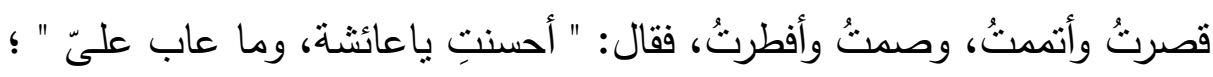

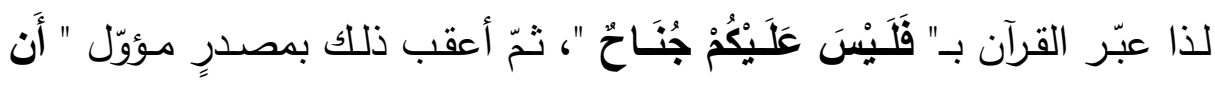

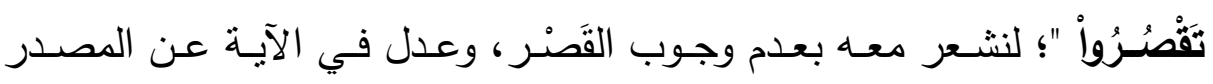

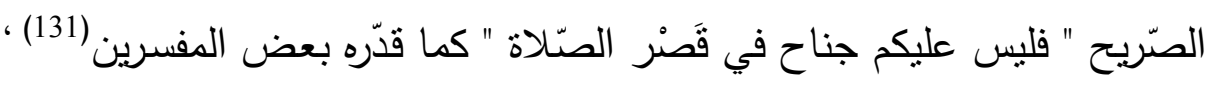

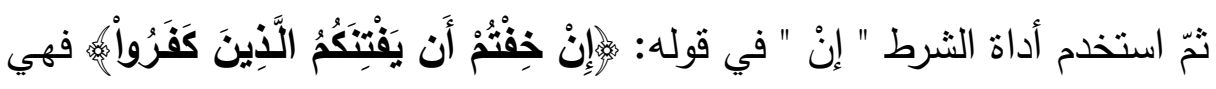

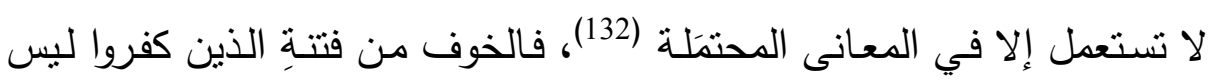
مقطوعاً به في كلّ سفرٍ ، فكان التعبير بـ " إنْ " لعدم القطع في الأثشياء الجائز

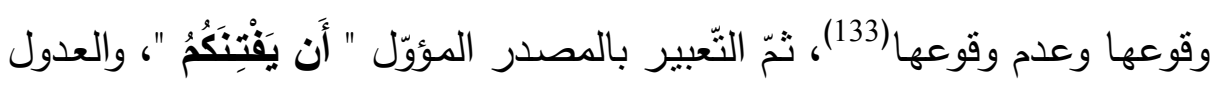

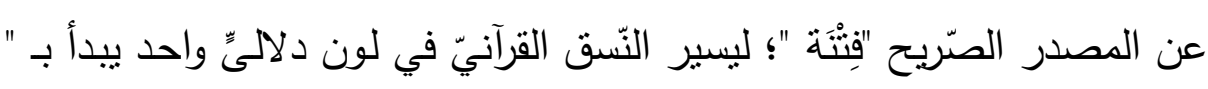

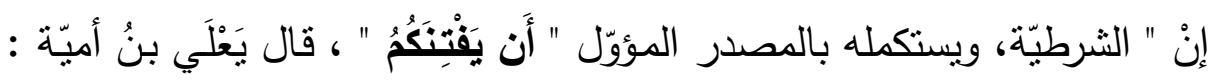

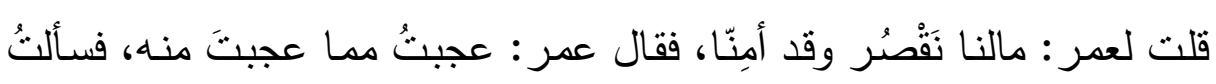

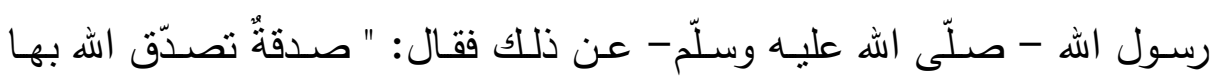

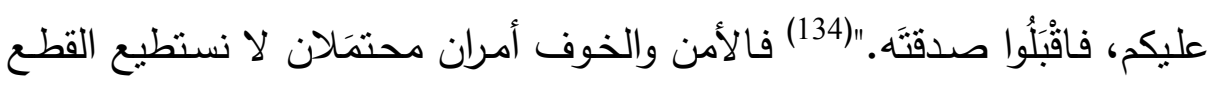
بأحدهما، والخوف من الفتتة يزول في حالات الأمن والاستقرار ؛ لذا لم يعبّر

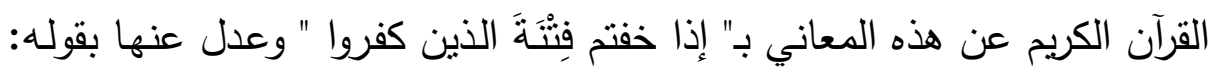

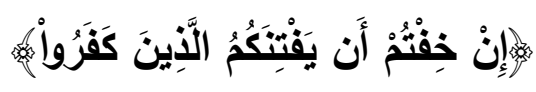

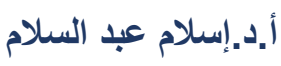
(تحولات المصادر في السياق القر آني دراسة دلالية.........) 
فإذا ما تحدّث المولى عزّ وجلّ عن أمرٍ متيقنٍ الوقوع، وقد قطع علاّم

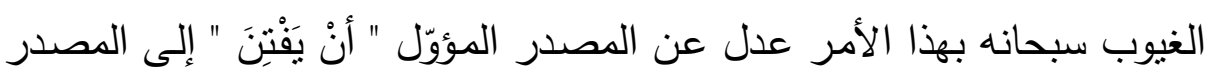

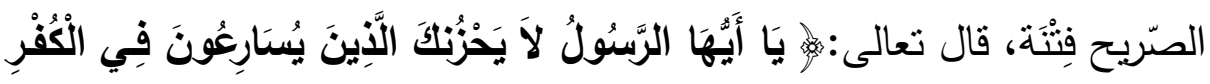

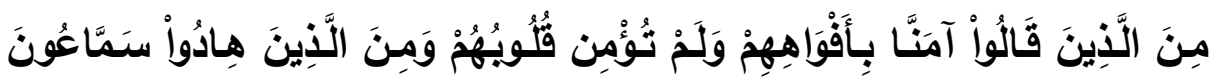

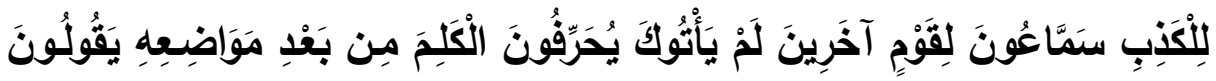

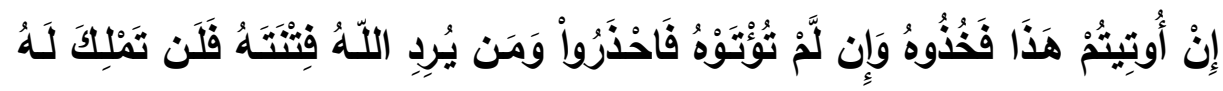

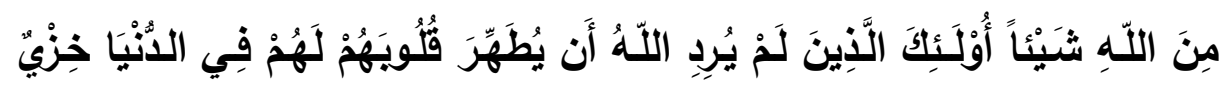

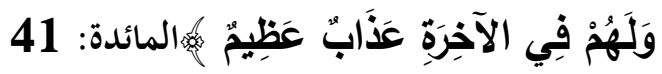
تتحدّث كتب التّقاسير (135) عن سبب نزول هذه الآيـة، وأنّها نزلت في

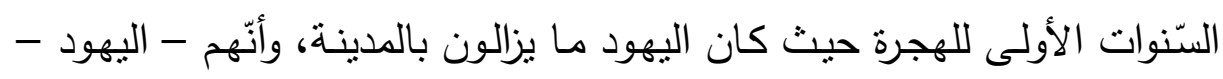

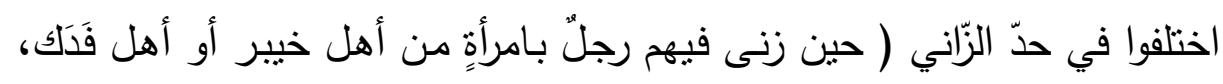

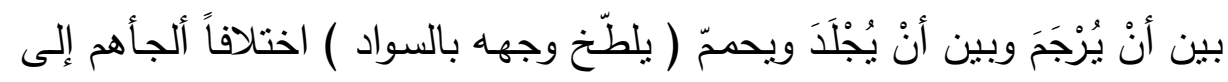

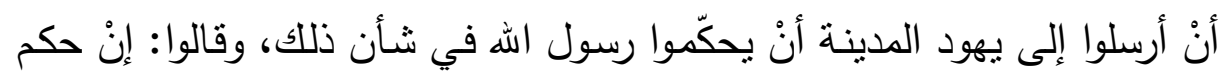

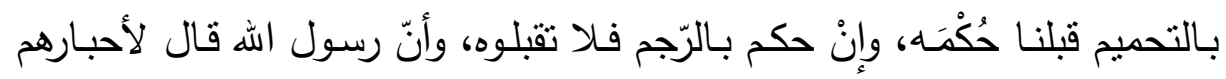
بالدينة: " ما تجدون في التّوراة على من زنى إذا أحصن، قالوا: يحمّّ ويجلد

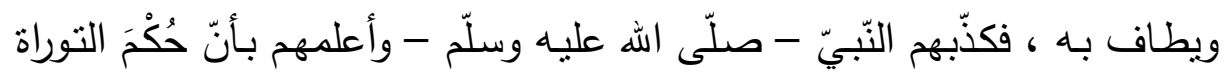

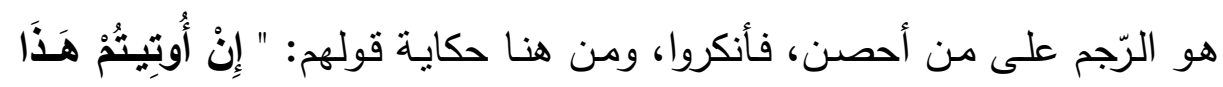

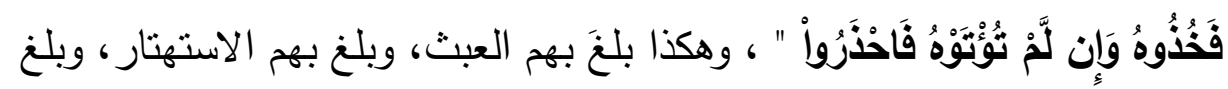

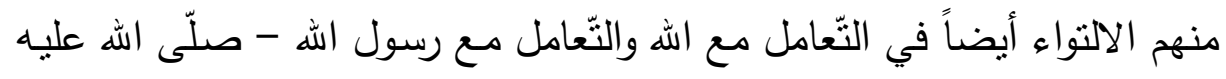

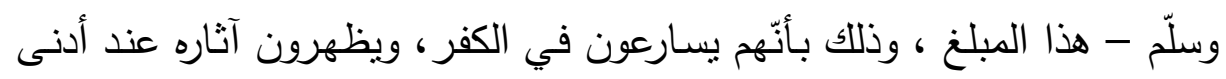




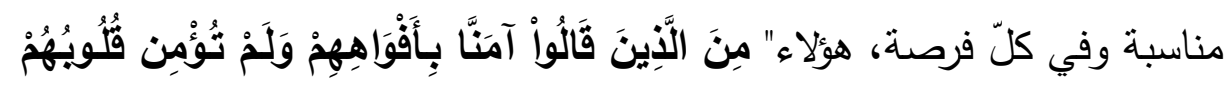

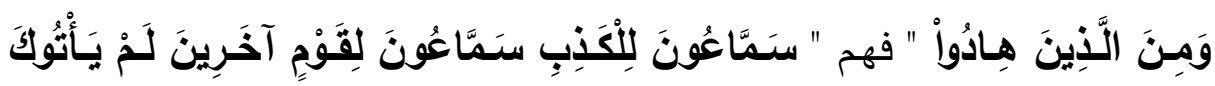

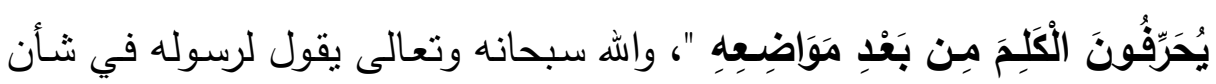

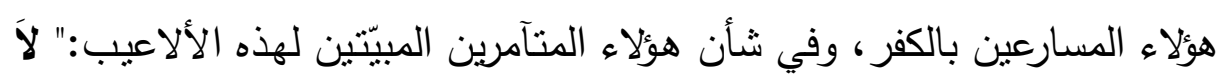

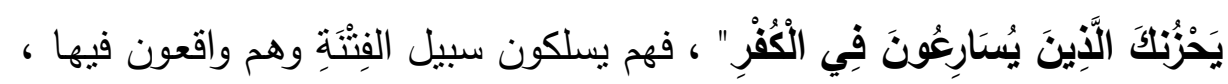

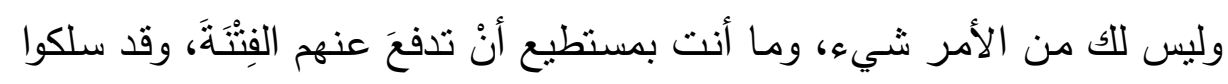

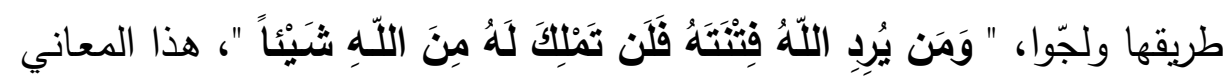

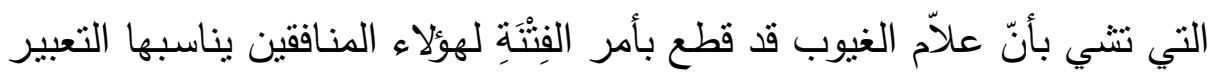

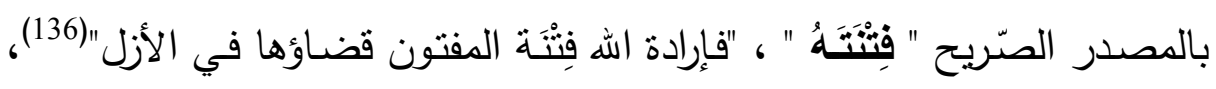

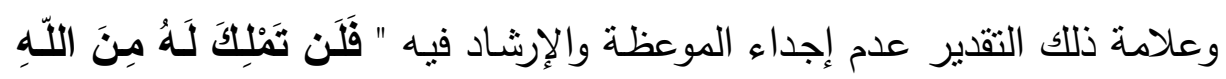

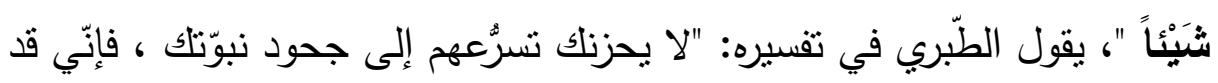

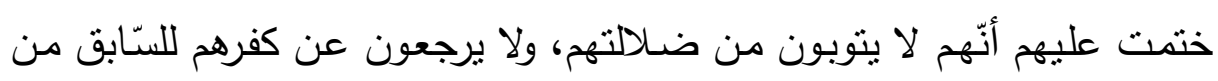
غضبي عليهم." (137)

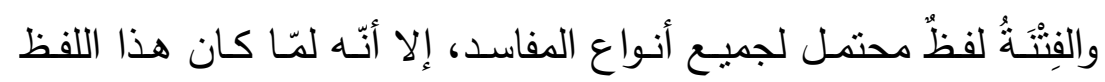

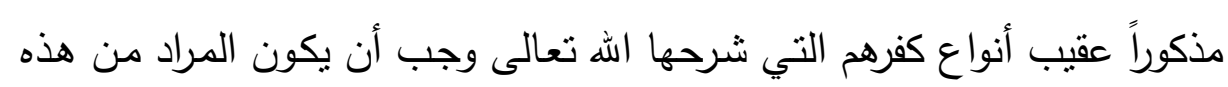
الفِتْنَة تلكَ الكفريات التي تقدّم ذكرها، وعلى هذا التقدير فالمراد: "ومن يرد الهه كفرَه وضلالته فلن يقدرَ أحدُ على دفع ذللك عنه."(138) 


\section{الخاتمة}

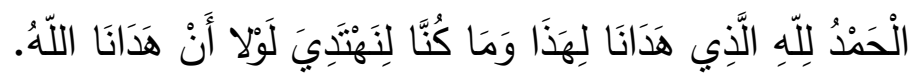

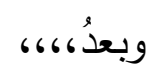

فإنّ لكلّ بحثٍ نتائجَ يهدف إليها، وبحثي هذا "العدول عن المصدر

الصّريح إلى المؤوّل في القرآن الكريم دراسـة دلاليّة" سعيتُ فيه إلى الكثف

عن النّكت الدلاليّة لعدول القرآن الكريم عن المصدر الصّرِيح إلى المصدر المؤوّل في صيغٍ من جذرٍ واحدٍ من خلال السّياق القرآنيّ، واستقراء نصوصـه، معتمِداً في ذلك على كتب التّاسير المختلفة، ومراجـع النّحو العديدة، حيث

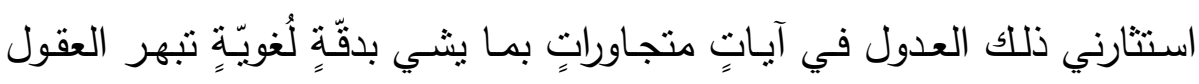
وتأخذ بنواصي القلوب، وأنّ الأمر لم يوضع اعتباطاً . ومن النتائج التي توصّل البحث إليها من خلال استقراء النّصّ القرآنيّ بنظرة دلاليّة سياقيّة ما يأني:

1- يعدل السّباق القرآنيّ عن المصدر الصّربح ويعبّر بالمصدر المؤوّل إذا

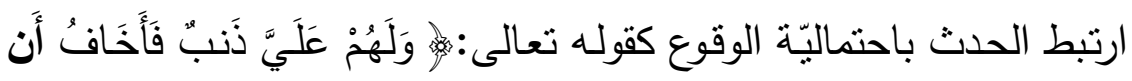

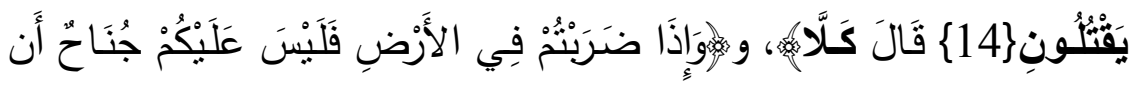

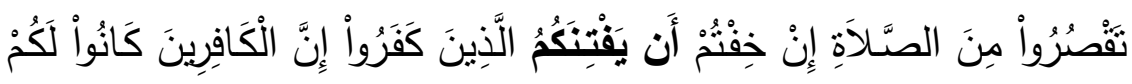

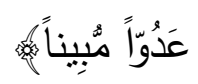

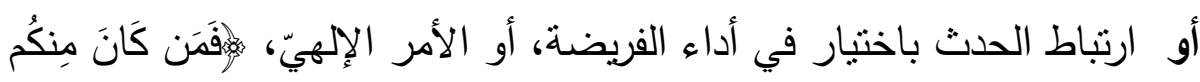

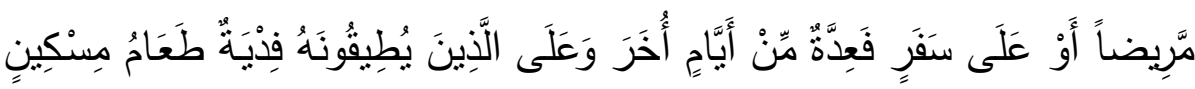

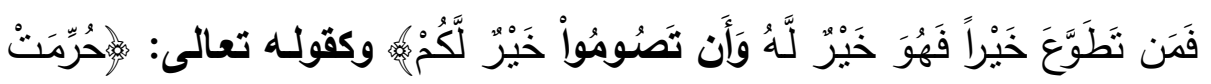




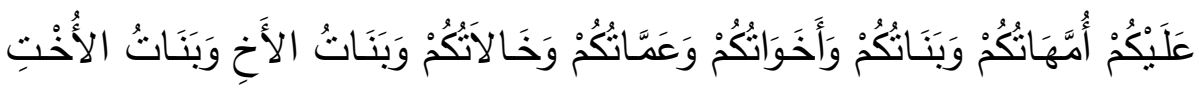

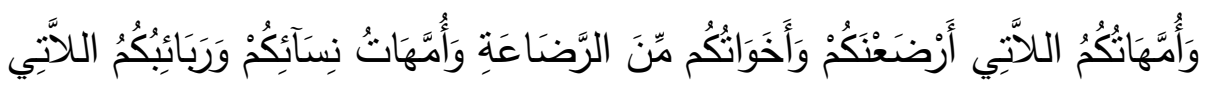

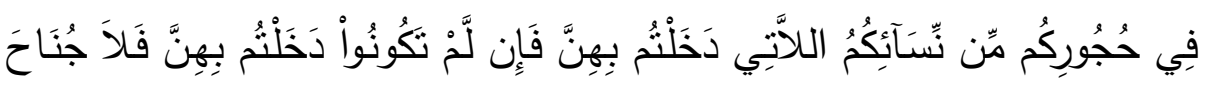

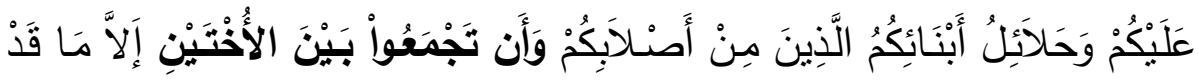

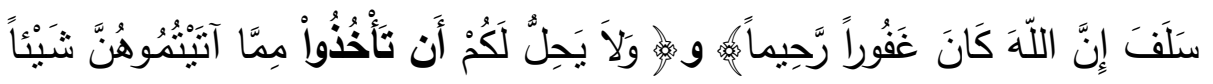

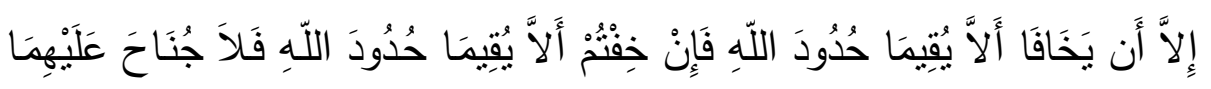

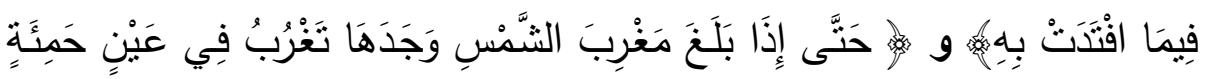

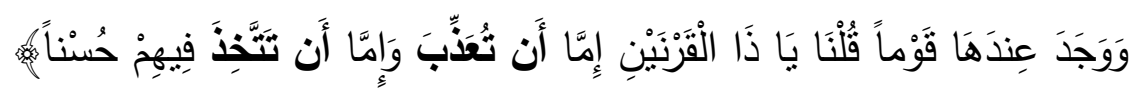

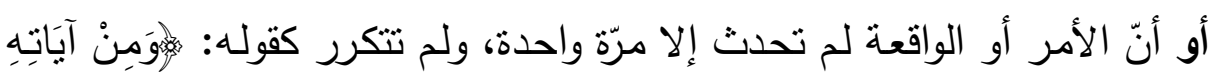

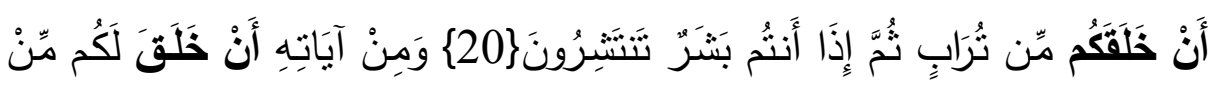

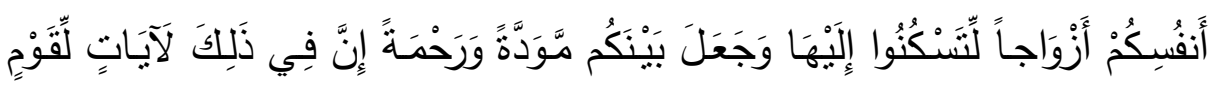

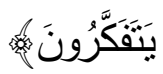

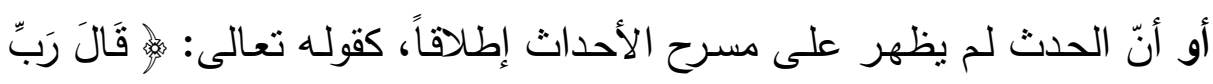

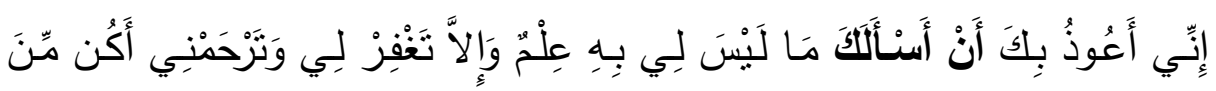

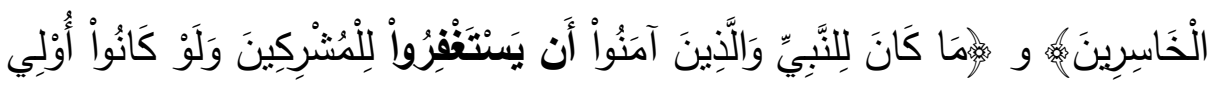

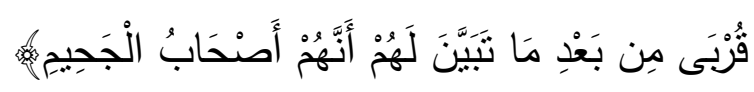

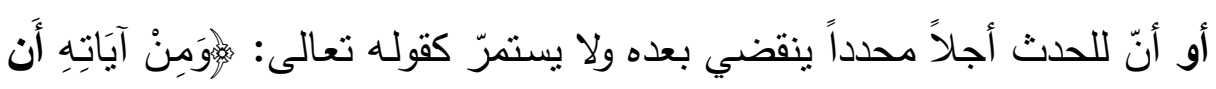

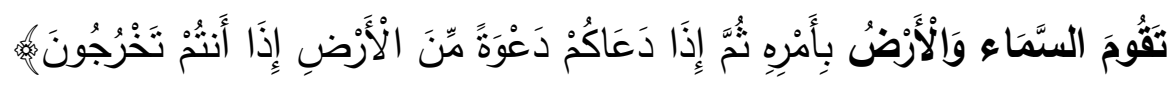

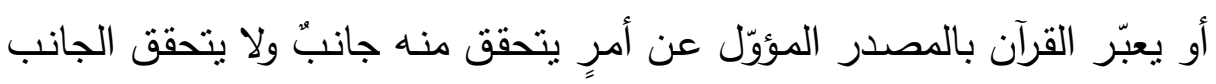

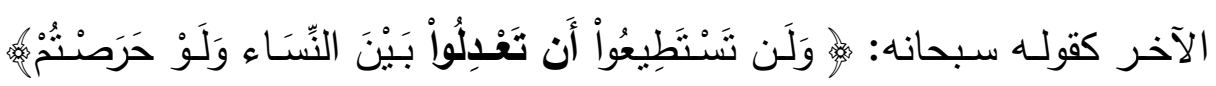


حيث هناك عدلٌ لا يتحقق، وهو العدل الحُبّيّ أو العدل القلبيّ، وهناك عدلٌ يتحقق وهو العدل الماديّ.

2- يعبّر السّياق القرآنيّ بالمصدر الصّـريح إذا كان الحدثُ واقعـاً لا محالـة

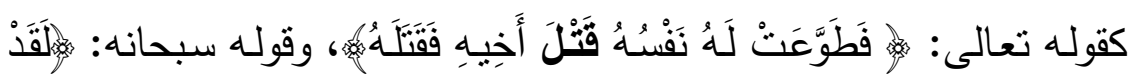

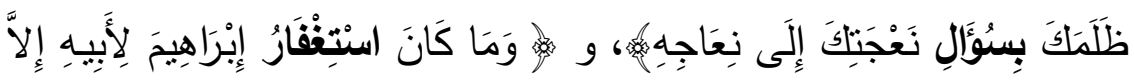

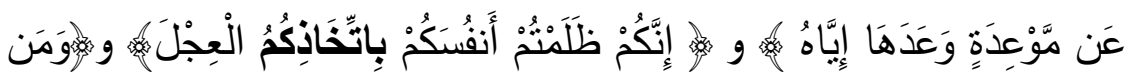

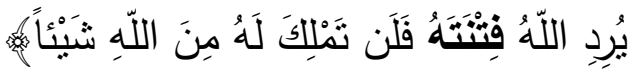

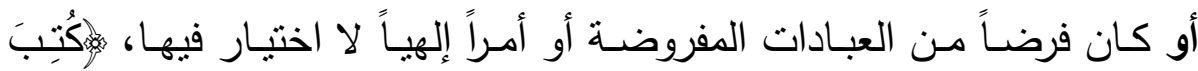

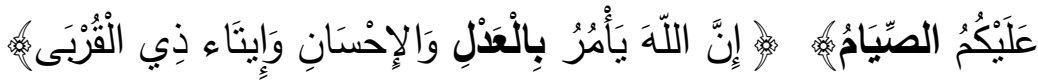

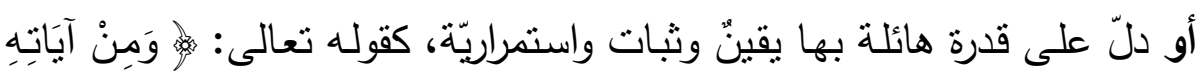

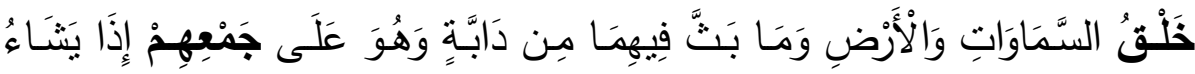
قَدِيرُ ومن تلك الإشارات الدلاليّة داخل نطاق البحث وخاتمته تظهر لنا علّة العدول عن المصدر الصّريح إلى المصدر المؤوّل من خـلد نصوص القرآن

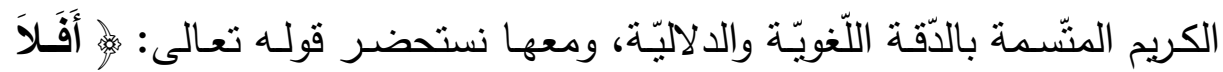

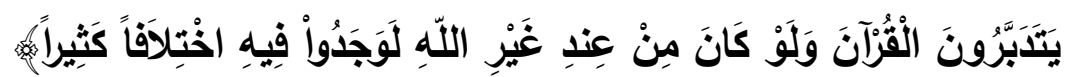
وأخيراً أدعو الله أنْ يجعل تللك التأمّلات والقراءات في ميزان حسناتي يوم لا ينفع مالٌ ولا بنون، وأنْ ينفع بها المسلمين أجمعين ، آمين. وما توفيقي إلا بالله عليه توكلتُ وإليه أنيب. 


\section{الـهوامش}

1. د. إسـلام عبد السّـلام، اسـم الفاعل بـين التّــوين والإضـافة في القـرآن الكريم (دراسـة دلاليّة)، مجلّة كليّّة دار العلوم- جامعـة الفيوم، العدد

$$
\text { 2008، 20" }
$$

2. د. إسـلام عبد الستّلام، أثثر الستّياق في بيـان الأوجـه الإعرابيّة "دراسـة

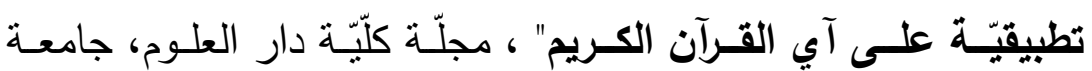

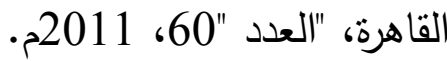

$$
\begin{aligned}
& \text { 3. الثّبّة: } 113 \text { - } 114 . \\
& \text { 4. الرّوم:20-22. }
\end{aligned}
$$

5. د. رجب حجّاج، المصدر المركّب في القرآن الكريم دراسة نحويّة دلاليّة، مجلّة كلّيّة دار العلوم ، جامعة الفيوم، 2011م، ص3. 6. طالع مـادة " عدل "في: ابن منظور ، لسـان العرب،ط1، دار صـادر، بيـروت، لبنـان،2000م ، و الراغب الأصبهاني، المفردات في غريب القرآن، تحقيق: د. محمّد أحمد خلف الله، مكتبة الأنجلو المصريّة. 7. الخليل بن أحمد، كتاب العين، تحقيق: د. مهدي المخزومي، د.إبراهيم السامرائي، سلسلة المعاجم والفهارس، د. ت، ج 38/2- 39 .

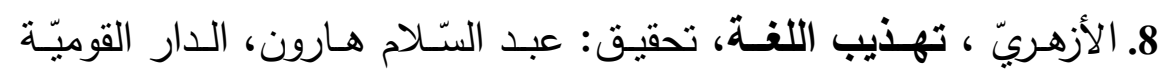
العربيّة للطباعة، مصر ، 1384هـ ، 1964م، ج 2 /209 . 9. ابن السّرّاج، الأصسول في التّحو، ط2،تحقيق: د. عبد الحسين الفتلي، مؤستسة الرّسالة، ، 1407هـ، 1987م، ج 88/2 ـ 
10. الجرجـاني، المقتصـــ فــي شـرح الإيضــاح، نحقبق: د. كـاظم بحر المرجان، دار الرشيد، العراق، 1982م، 1007 وما بعدها .

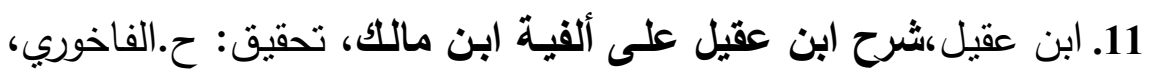

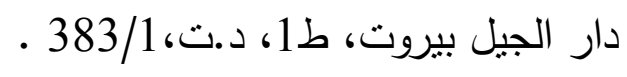

12. د. محمّد عبد المطلب، البلاغة والأسلوب، ط1، مكتبة لبنان، لونجمان،

$$
\text { 1994م، ص268. }
$$

13. د. عبد الحميد هنداوي، الإعجـاز الصَّرفيّ في القـرآن الكريم" دراسـة

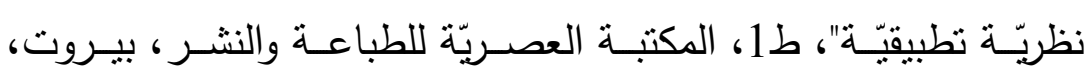

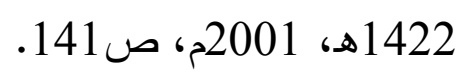

14. د. عبد العزيز عبد الله، ظاهرة العدول بين البلاغة العربيّة والأسلوييّة

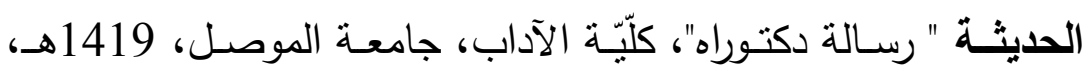

$$
\text { . } 37 \text { 1990م،ص } 39
$$

$$
\text { 15. (15)ابن منظور، لسان العرب مادّة (ص،د،ر). }
$$

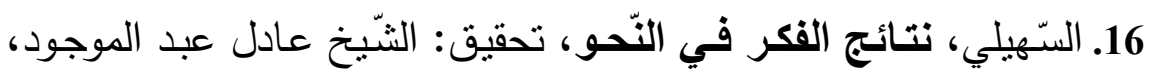

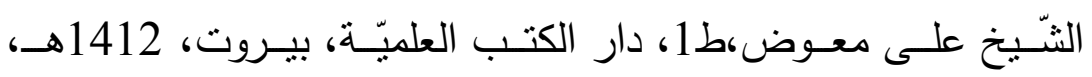

$$
\text { 1992م، ص53، 515، } 58 .
$$

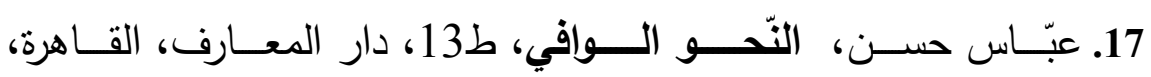

$$
\text { د.ن، 181/3. }
$$

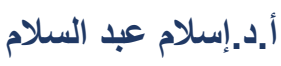

(تحولات المصادر في السياق القرآني دراسة دلالية.........) 
18. طالع أبا حيّان الأندلسيّ، ارتثـاف الضّرب من لسـان العرب، تحقيق: د.رجب عثمـان محمّـد ، ط1، مكتبـة الخـانجي، القـاهرة ، 1428هـ، 1998م،ص4991، 992، عبّاس حسن، النّحو الوافي، ج407/1 .

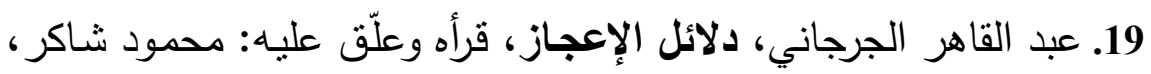

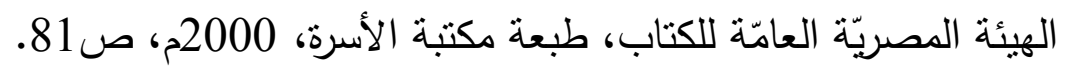
20. سييويه، الكتاب، تحقيق: عبد اليّالام هارون، ط3، مكتبة الخانجي ، القاهرة، 1408هـ، 1988م، ج25/1 26،25. 21. ابن قيم الجوزية، بائع الفوائد، تحقيق: على بن محمّد العمران، مجمع

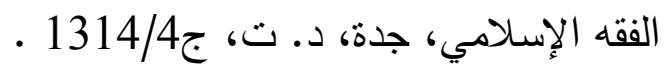

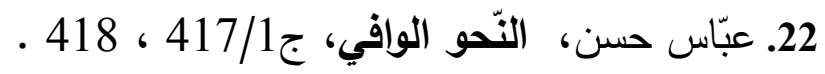
23. د. طه الجندي، المصدر المؤوّل بحث في التركيب والدلالة، دار الثقافة

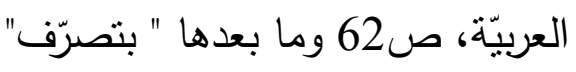

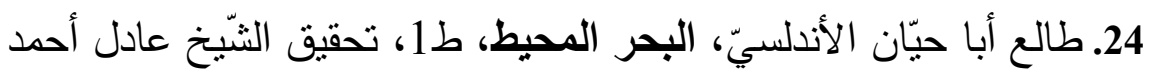

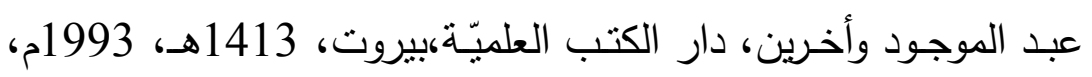
ج476/3 وما بعدها، أبا السعود محمد بن العمادي، إرشاد العقل السليم إلى مزايا الكتاب الكريم(تفسير أبي السعود) ، دار إحباء التراث العربيّ،

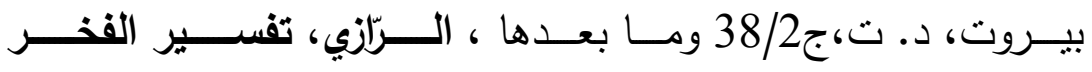

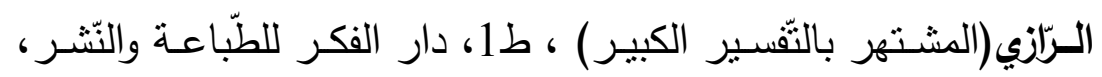

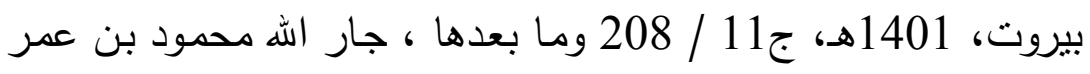
الزمخشري، الكثـاف عن حقائق التنزيلـل وعيـون الأقاويل في وجهوه 
التأويل،تحقيق: يوسف الحماديّ،مكتبة مصر ، الفجالة، د.ت.ج21/2، السّمين الحلبيّ، الدّرّ المصون في علم الكتاب المكنون، تحقيق: أحمد

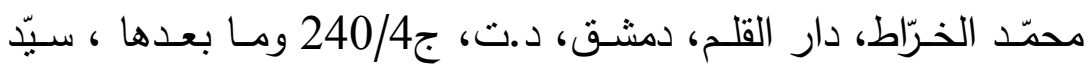
قطب، في ظـلال القـرآن، ج874/15 ومـا بعدها، تفسير الثَّعراوي، ج3067/5، تفسير الطبري 8/ 323، ابن عاشور، تفسير التّمرير والتّوير، الدار الثّونسيّة للنشر، 1984م، ج168/6 وما بعدها. 25. سيّّ قطب، في ظلال القرآن، ج250/51. 26. طالع أبا حيّان الأندلسيّ، البحر المحيط، ج9/9، أبا السعود العمادي، إرشاد العقل السليم،ج 237/6.

27. الزّجاج ،معاني القرآن وإعرابه، تحقيق: د.عبد الجليل عبده شلبي، ط1، عالم الكتاب، بيروت، ، 1408هـ، 1988م،ج85/4، وطالع القرطبيّ، الجامع لأحكام القرآن، تحقيق: د.عبد الله الترّكي، ط1، مؤسّسة الرّسالة،

$$
\text { بيروت، 1427هـ، 2006م، ج14/16. }
$$

28. ابن عاشور ، التّحرير والنّوير ، ج 135/2.

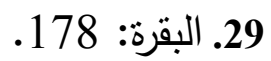

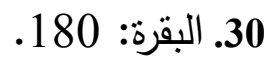

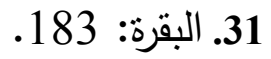

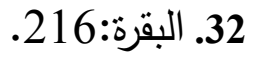

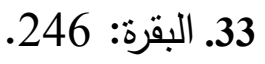

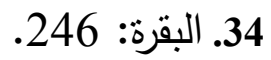


35. طالع الآلكسيّ البغدادي، شهاب الدين السيّّ محمود، روح المعاني في تفسير القرآن العظيم والسبع المثاني، دار إحياء التراث العربيّ، بيروت، د.ت، ج59/2، أبـا حيّان الأندلسيّ، البحر المحيط، ج43/2، 42، أبـا السعود، إرشـاد العقل السليم، ج199/1، تفسير الرّّازى، ج85/5، سيّّ قطب، في ظـلال القـرآن،ج171/، محمّد منـولي الثَّعراوي، تفسـير الثَّعراوي، طبعـة دار أخبار اليوم، ج770/2 ، ابن عاشـور، التّحريـر

$$
\text { والتّوير،ج2/262. }
$$

36. طالع القرطبيّ، الجامع لأحكام القرآن، ج149/3. 37. ابن عاثور، التّمرير والتّوير،ج ج 294/4. 38.

39. تفسـير الــرّازى، ج37/10، الزّجـاج، معـاني القـرآن وإعرابـه، 35/2، الزمخثــــريّ، الكثَّــــــاف 434/1، السّـــــين الحلبــــــ، الــــــرّر

$$
\text { المصون، ج645/3. }
$$

40. القرطبيّ، الجامع لأحكام القرآن،ج 197/6 ـ 41. تفسير الشَّعراوي، ج2109/4.

42. طـالع أبـا حيّـان الأندلسيّ، البحـر المحسيط، ج 221/3 ، ابـن عطيّة الأندلسيّ ،المحرر الوجيزفي تفسير الكتاب العزيز، تحقيق: عبد السّلام

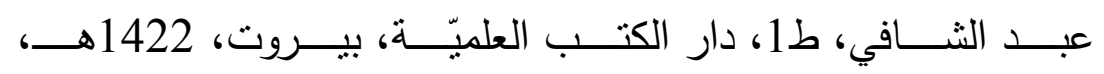

$$
\text { 2001م، ج21/201 }
$$

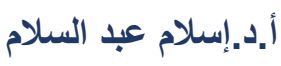

(تحولات المصادر في السياق القر آني دراسة دلالية.........) 
43. تفسير الرّازى، ج37/10،الزّجاج، معانى القرآن،ج 35/2، الزّمخشري،

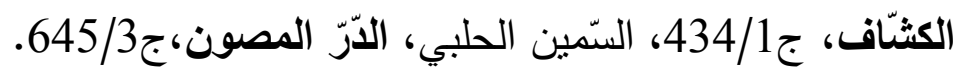

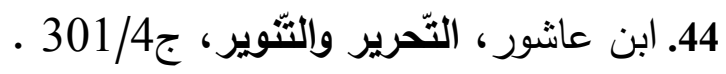
45. الثثّورى: 29. 46. الثّورى:28-32.

47. طالع سيّّ قطب، في ظلال القرآن،ج 3158/63. 315.

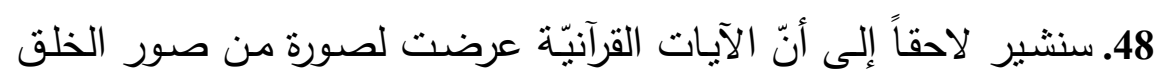

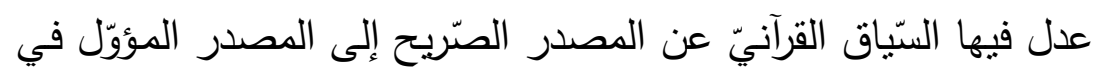

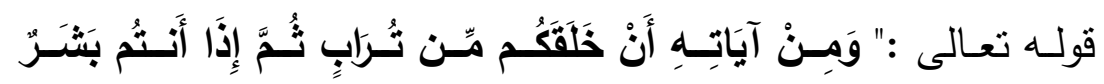

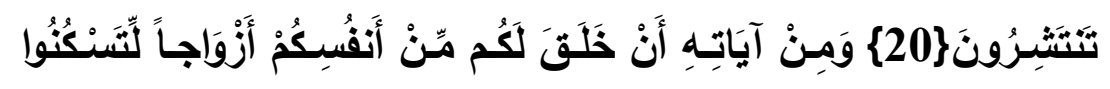

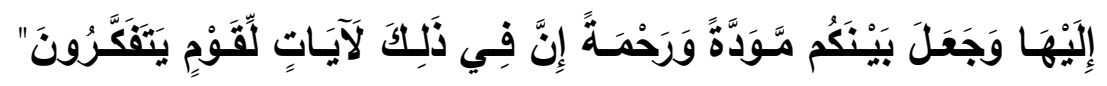

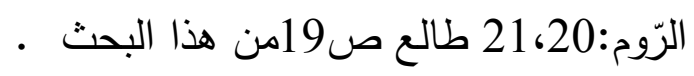

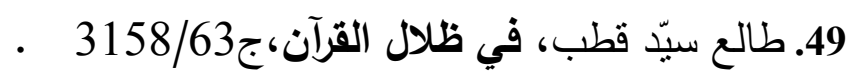

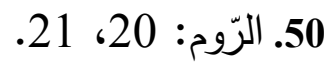

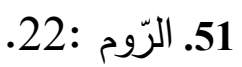

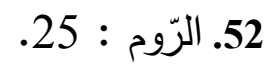

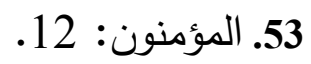
(71. 71.54

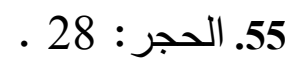


56. لجنـة من علمـاء الأزهر ،الوسـيط في تفسير القـرآن، مجمـع البحوث

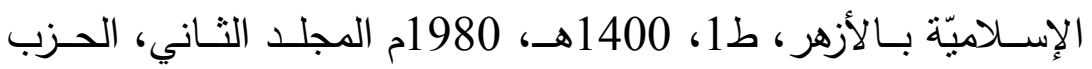

$$
\begin{aligned}
& \text { السابع والعشرون ص } 537 \text {. } \\
& \text { 57. المؤمنون :12 - 12. } \\
& \text { 58. الرّوم: 21. }
\end{aligned}
$$

59. طسالع في ذلك الآلكوسي، روح المعساني 30/21 ، أبـا السـعود، إرشـاد العقـل السـليم،ج 56/7، إسـماعيل بن عمر ابن كثير ،تفسير القـرآن العظيم، تحقيق: سامي بن محمد السـامة ، ط2، دار طيبة، الرياض ،

$$
\begin{aligned}
& \text { 1420هـ، 1999م، ج 309/6. }
\end{aligned}
$$

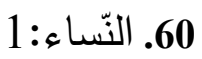

$$
\begin{aligned}
& \text { 61. الأعراف:189 }
\end{aligned}
$$

62. مسلم النيسابوري، الإمام الحافظ أبو الحسين مسلم بن الحجاج، صحيح مسلم، تحقيق:أبو قتيبـة الفارايابي،ط1، دار طيبة، الريـاض، 1427هـ، 2006م.كتاب الرضاع، باب الوصيّة بالنّساء، ص 672، رقم (1468) من حديث أبي هربرة رضي الله عنه.

63. ابـن عاثــور ، التّحريــر والتّـــوير، ج215/4 وطــالع الآلوسـي، روح المعاني،ج 182،181/4 ، وتفسير ابن كثير ، تفسير القرآن العظيم،

$$
\text { ج206/2. }
$$


64. سيّّ قطب، فـي ظـلال القـرآن،ج 574/9، وطـالع أبـا السـعود، إرشــاد العقل السـليم 302/3 ، سيّّ قطب، في ظـلال القـرآن، ج1411/26. تفسير الثُّعراوي،ج 4513/8، ابن كثير ،تفسير القرآن العظيم 524/3. 65. الآلوسي، روح المعاني، ج182/4. 66. سيّد قطب، في ظلال القرآن، ج575/9.

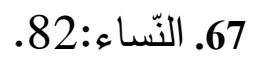
68. طالع ص17 من هذا البحث.

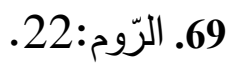
70. - 70

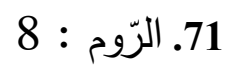

72. الآلكوسي، روح المعساني،ج 35/21، وطـالع أبـا السـود ،إرشـاد العقـل

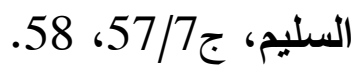

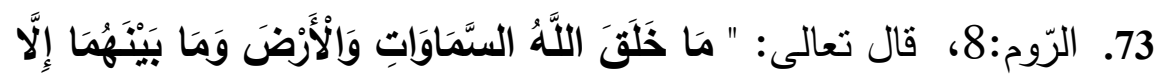
" بِالْحَقِّ وَأَجَلِ مُسنَفَّى 104: 74. الأنبياء

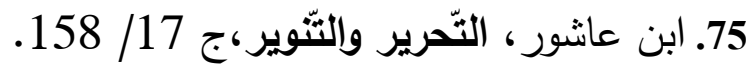

76. سيّد قطب، في ظلال القرآن ،ج47/ 2399 . 77. ســـّ قطــب، فـــي ظــلال القـــرآن، ج247/4، وطــالع تفســير الزّازى،ج106/6، ابن عطية، المحر الوجيز،ج 306/1 ـ 
78. الإمـام الحسافظ أبو عبد الله بـن محمد بـن إبراهيم البخـاريّ، صـيح

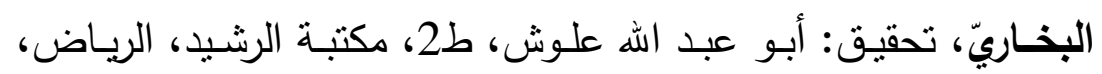

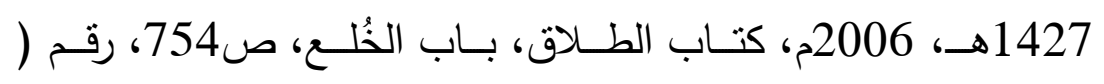

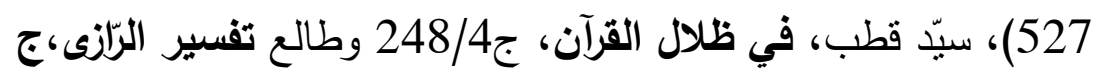

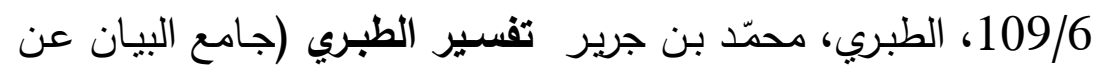

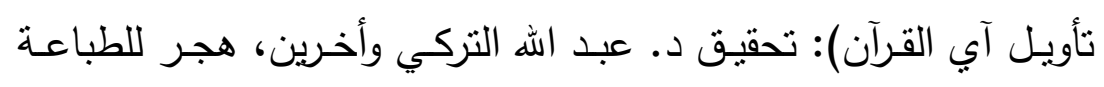

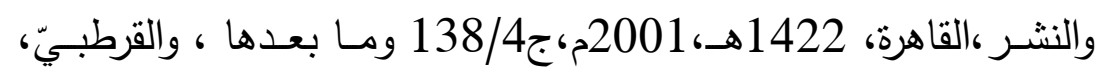

$$
\text { 79. السّمين الحلبي، الآدّ المصون، جأحكام القران، ج79/4 وما بعدها. }
$$

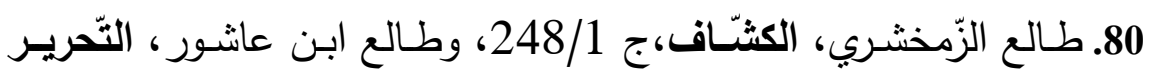

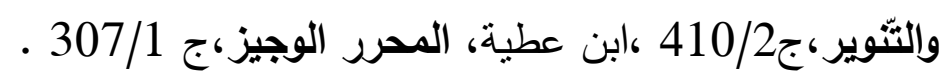

$$
\begin{aligned}
& 81 \text { هود: } 102 \text {. } \\
& \text { 82. هود : } 101 \text { - } 102 \text {. }
\end{aligned}
$$

83. طالع في ذلك سيّد قطب، في ظلال القرآن،ج 36/ 1870 وما بعدها، في ظلال القرآن،ج 137 / 1926 وما بعدها .

$$
\begin{aligned}
& \text { 84. هود : } 44 . \\
& \text { 85. هود: } 58 \text { - } 60 \text {. } \\
& \text { 86. هود: } 100 \text { - } 102 \text { ـ هرد }
\end{aligned}
$$

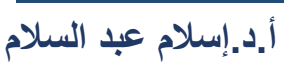

(تحولات المصادر في السياق القر آني دراسة دلالية..........) 
87. البخاريّ، صـيح البخـاريّ، كتاب التفسير سورة هود، ص 647، رقم (4686 )، مســلم، صـــيح مســلم، كتـاب البـرّ والصّـــة والآداب،

$$
\text { ص1200 رقم (2583). }
$$

88

$$
\text { . 89. هود: } 42 \text { - } 42
$$

90. طالع في ذلك ابن عاشور ، التّحرير والتّوير ج12/ 83 ما بعدها .

$$
\text { 91. مريخ: 3، } 4 .
$$

$$
\text { 92. الزّمخشري، الكثاف، ج 406/2. }
$$

93. المائدة: 6، وطالع الزّخششري، الكثّاف، ج 10/2 في حديثه عن التعبير

عن إرادة الفعل بالفعل .

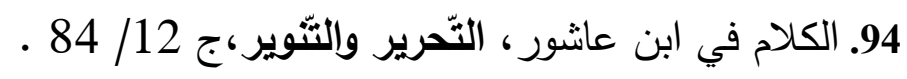

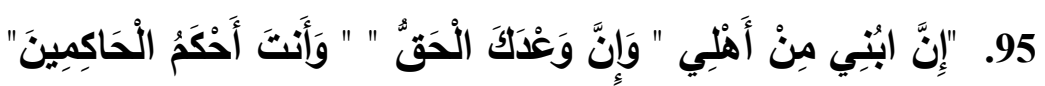

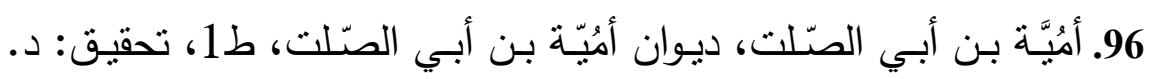
سجيع جميل، دار صادر ، بيروت، 1998م، ص17، وطالع أبا بكر محمّد بن الحسن بن دريد، الاشتقاق، ط1، تحقيق: عبد السّام هارون،

دار الجيل، بيروت، 1411هـ، 1991م،ص 143 ـ

97.

98. طالع ابن عاشتور ، التّحرير والتّوير، ج12/ 87 . 99. المرجع السابق، ج12/ 88 ـ 100. تفسير الثَّعراوي، ج11/ 6485 


$$
\begin{aligned}
& \text { 101. سيّد قطب، في ظلال القرآن،ج 60/ 3018. } \\
& \text { 102. التّبة : } 80 \text {. }
\end{aligned}
$$

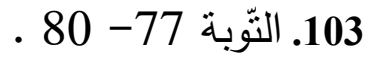

104. البخـاريّ، صـحيح البخـــيّ كتـاب التفسـير - التوبـة، ص 643، رقم (4670)، مسـلم، صـحيح مسـلم، كتـاب فضـائل الصـحابة رضـي الله

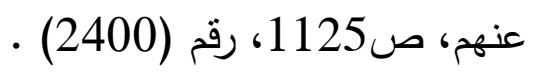

105. المنافقون :5.

106. طـالع أبـا حيَّن، البحر المحيط، ج 77/5 ومـا بعدها، أبـا السّـعود، إرشــاد العقل السـليم ج87/4 ، تفسير الـرّزى، ج 49/16 ومـا بعدها،

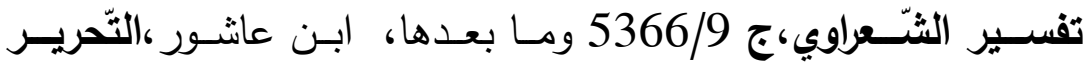

$$
\text { والتّوير، ج 277/10 وما بعدها. }
$$

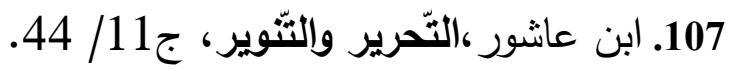

$$
\begin{aligned}
& \text { 108. إبراهيم: 39- } 41 \text {. } \\
& \text { 109. الثّعراء: } 86 . \\
& \text { 110. مريم : } 46 \text { - } 47 \text {. }
\end{aligned}
$$

111. ابن عاثور ،التّمرير والتّوير،ج 14/ 254.

112. سيّّ قطب، في ظلال القرآن،ج 2190/42

113. القرطبيّ، الجامع لأحكام القرآن،

114. الملك : 14

115. النّساء : 129 . 
116. سيّّ قطب، فـي ظـلال القـرآن،ج 770/13 وطـالع الآلوسـي، روح

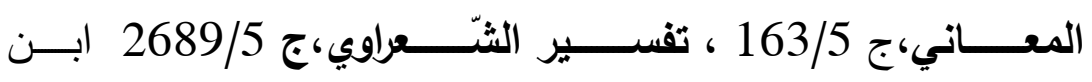

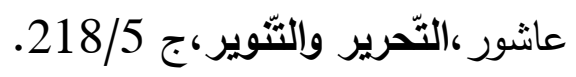

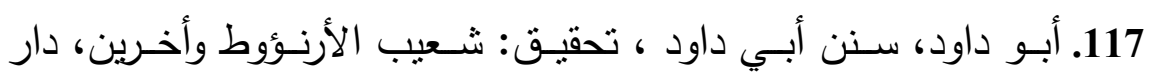

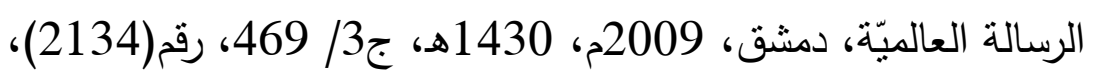

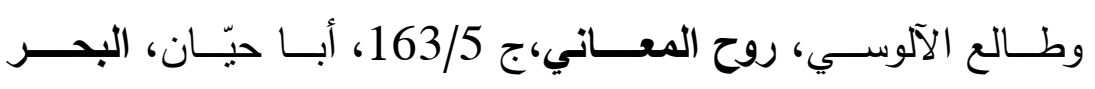
المحيط،ج3/381،تفسير الرازي، ج11/ 68، الستيوطي، جلال الدين،

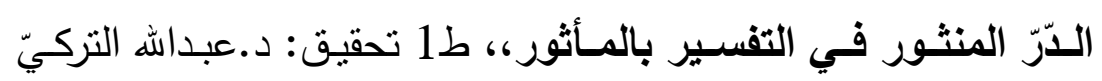

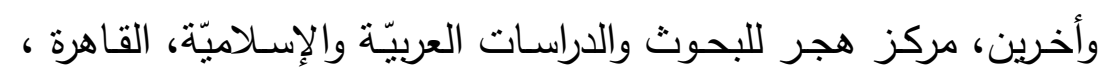

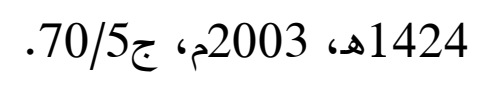

118. ابن عاثور، ،التحرير والتنوير،ج 218/5.

119. طالع الآلوسي، روح المعاني،ج 44/16 ، أبا السعود، إرثـاد العقل

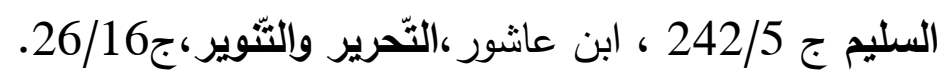

120. طالع الآلوسي، روح المعاني، ج34/16 ، أبا السعود، إرشـاد العقل

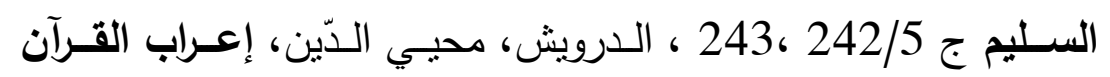

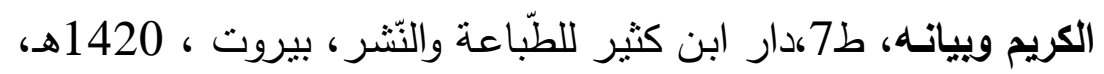

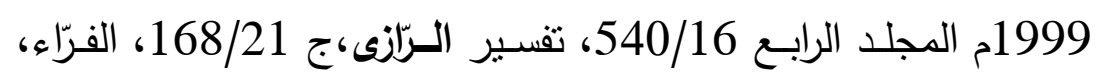
يحيى بن زكريا ، معاني القرآن، عالم الكتب، بيروت، ط3، 1403هـ،

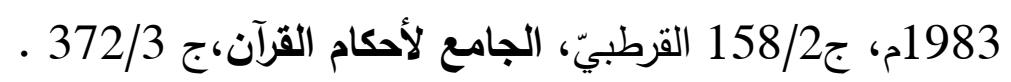


121. طـالع أبـا حيّان، البحـر المدـيط،ج 152/6، تفسـير الثـــعراوي،

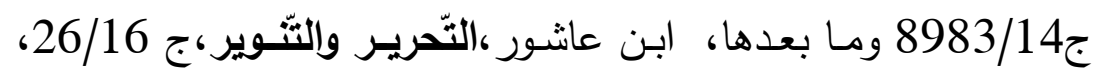

$$
\begin{aligned}
& \text { 122. الأعراف : } 138 \text {. } \\
& \text { 123.طه : } 83 \text {-88. }
\end{aligned}
$$

124. طالع الآلوسي، روح المعـاني،ج 259/1، أبـا السعود، إرثــاد العقل

$$
\text { 125. البقرة:93 . 102/1. }
$$

126. سيّد قطب، في ظلال القرآن،ج 91/2 .

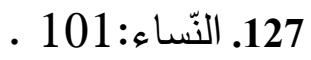

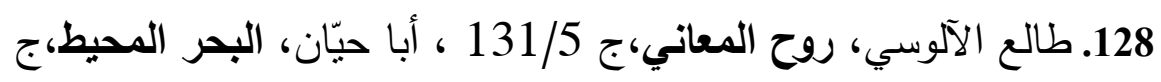

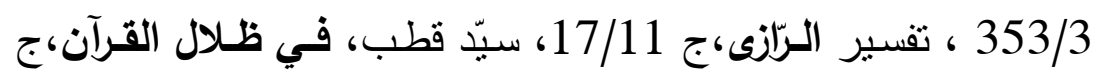

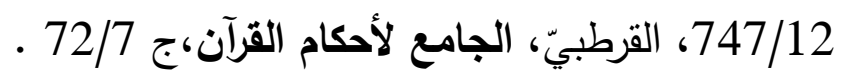

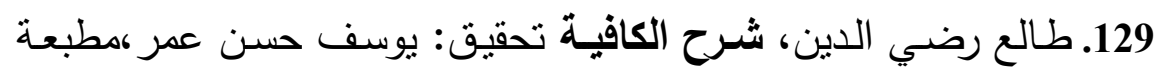

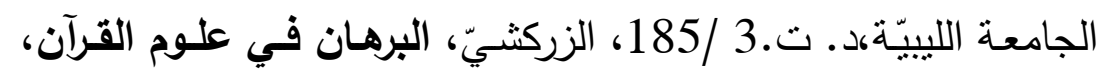
ط1، تحقيق: مصطفى عبد القادر عطا، دار الكتب العلميّة، بيروت، 1408هـ، 1988م،ج 374/2، سيبويه، الكتاب، تحقيق: عبد النّام هارون، ط3، مكتبة الخانجي، القاهرة، 1408هـ، 1988م ،ج 58/3،

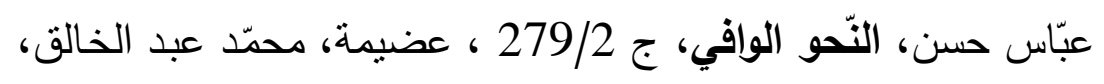

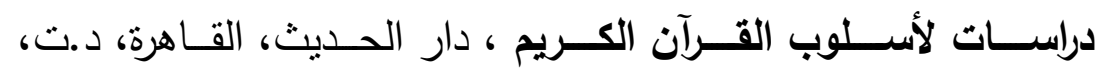


173/1، المبرد، محمّد بن يزيد، المقتضب،تحقيق: محمّد عبد الخالق

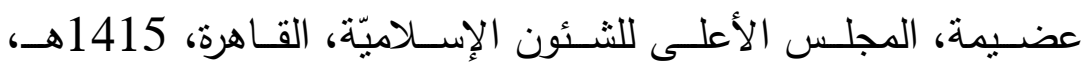

$$
\text { 1994م، ج 54/2 وما بعدها . }
$$

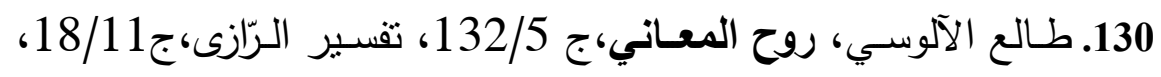
الزمخشريّ، الكثّــاف، 484/1، القرطبيّ، الجـامع لأحكـام القـرآن،

$$
\text { ج73/7 . }
$$

131. السّمين الحلبي، الدّّ المصون، ج83/4 ـ

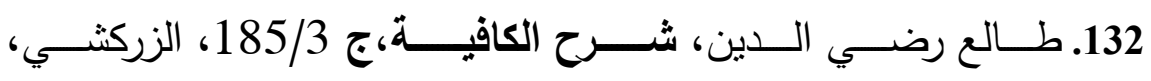
البرهان،ج374/2، سييويه، الكتاب 58/3، عضيمة، دراسـات لأسلوب القرآن الكريم،جم628/1، المبرد، المقتضب،ج 54/2 وما بعدها.

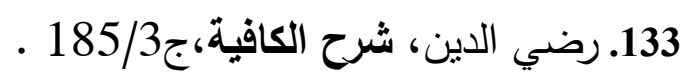

134. القرطبيّ، الجامع لأحكام القرآن،ج

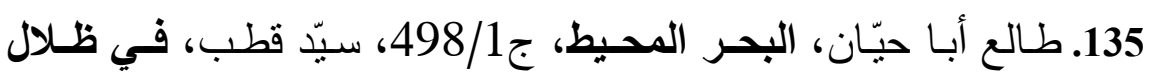

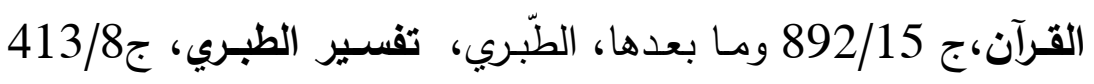

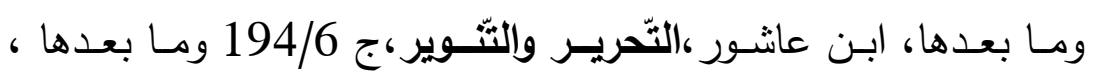

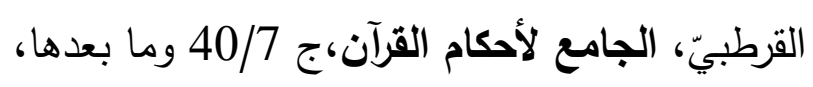

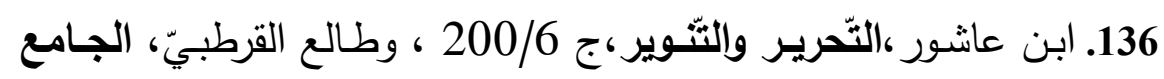

$$
\begin{aligned}
& \text { لأحكام القرآن ج 285/1 ، 367، 31/5، 484/7 } \\
& \text { 137. الطَّبري، تفسير الطَّبري،ج }
\end{aligned}
$$

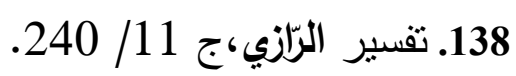

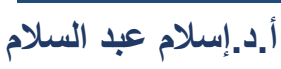

(تحولات المصادر في السياق القرآني دراسة دلالية..........) 


\section{المصادر والمراجع}

- الآلوسي البغداديّ، أبو الفضل شهاب الدين السيّّ محمود، روح المعاني في تقسير القرآن العظيم والسبع المثناني، دار إحبـاء التـراث العربيّ، بيـروت،

د.ت.

- - أبو حيّان الأندلسيّ، محمّد بن يوسف، ارتثـاف الضّرب من لسـان العرب، تحقيق: د.رجب عثمان محمّد ، ط1، مكتبة الخانجي، القاهرة ، 1428هـ، •1998

- أبو حيّان الأندلسيّ، محمّد بن بوسف، البحر المحيط، ط1، تحقيق الثيخ عـادل أحمد عبد الموجـود وأخرين، دار الكتب العلميّة،بيروت، 1413هـ، •1993

- - أبو داود، سـن أبي داود ، تحقيـق: شـعيب الأزنؤوط وأخرين، دار الرسـالة العالميّة، دمشق، 20092، 1430هـ، - - أبو السّعود محمّد بن محمد العمادي، إرشّاد العقل السليم إلى مزايـا الكتاب الكريم( تفسير أبي الستّود) ، دار إحياء التراث العربي، بيروت، د. ت - الأزهريّ ، أبو منصور محمّد بن أحمد، تهذيب اللغة، تحقيق: عبد السّلام هارون وأخرين، الدار القوميّة العربيّة للطباعة، مصر، 1384هـ ، 1964م. - أُميَّة بن أبي الصّّلت، ديوان أُميّةة بن أبي الصّّلت، ط1، تحقيق: د. سجيع جميل، دار صادر ، بيروت، 1998م. 
- البخاريّ، الإمام الحافظ أبو عبد الله بن محمّد بن إبراهيم، صحيح البخاريّ،

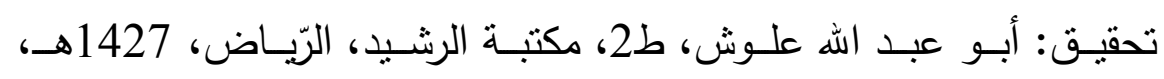

.2006

- الجرجاني ، أبو بكر عبد القاهر بن عبد الرحمن ،دلائل الإعجاز، قرأهوعلّق

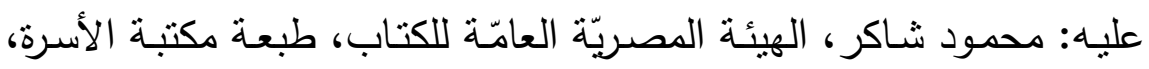

.2000

- الجرجاني، أبو بكر عبد القاهر بـن عبد الرحمن، المقتصــ فـي شـرح الإيضاح، تحقيق: د. كاظم بحر المرجان، دار الرشيد، العراق، 1982م.

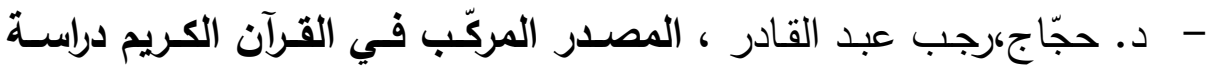

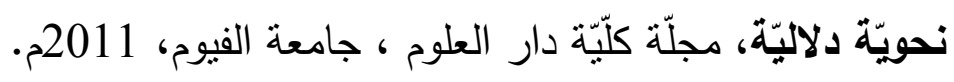
- حسن ، عبّاس، النّّو الوافي، ط13، دار المعارف ، القاهرة، د.ت. - الدّرويش، محيي الدّين، إعراب القرآن الكريم وبيانسه، ط7،دار ابن كثير

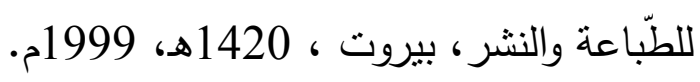

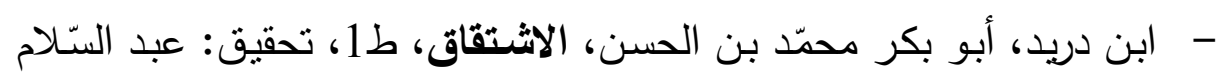
هارون، دار الجيل ، بيروت ، 1411هـ، 1991م.

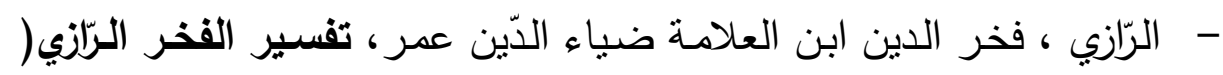

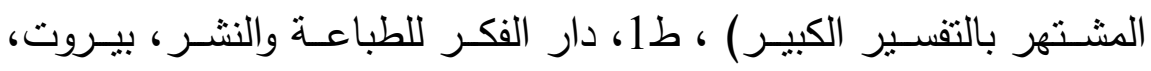
1401

- الراغب الأصبهاني، الحسين بن محمّد، المفردات في غريب القرآن، تحقيق: د. محمّّ أحمد خلف الله، مكتبة الأنجلو المصرية، د. ت.

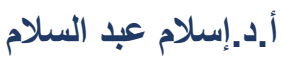
(تحولات المصادر في السياق القر آني دراسة دلالية.........) 
- رضي الدين، محمد بن الحسن الاستراباذي، شرح الكافية، تحقيق: يوسف حسن عمر،مطبعة الجامعة الليبية، د. ت. تصن

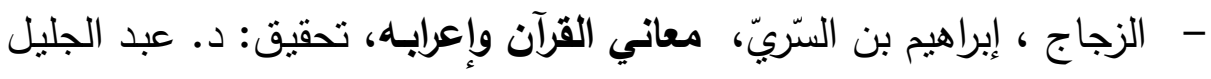

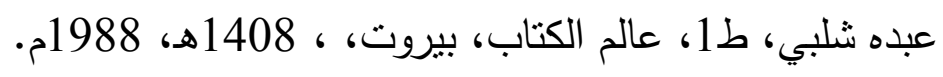

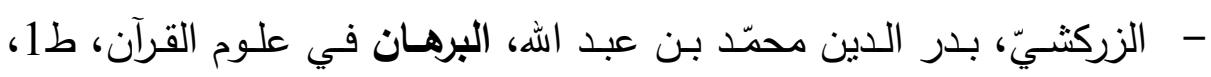
تحقيق: مصطفى عبد القادر عطا، دار الكتب العلميّة، بيروت ، 1408هـ، 1988 - الزمخشريّ،أبو القاسم جار الله محمود بن عمر، الكثّاف عن حقائق التنزيل

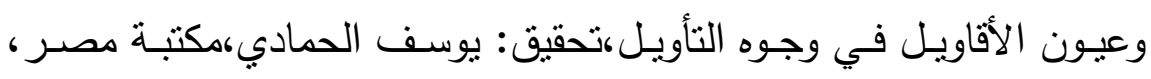

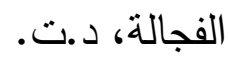

- ابن السّراج، أبو بكر محمّد بن سهل ، الأصول في النّحو، ط2،تحقيق: د. عبد الحسين الفتلي، مؤسسة الرسالة، ، 1407هـ، 1987م.

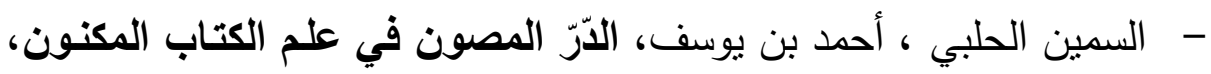
تحقيق: أحمد محمّد الخرّاط، دار القلم، دمشق، د.ت.

- السهيلي، أبو القاسم عبد الرحمن بن عبداله، نتائج الفكر في النحو، نحقيق:

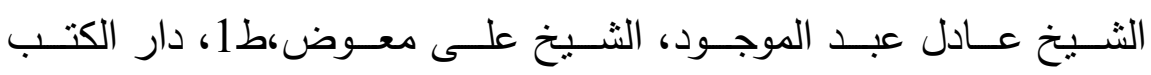
العلمية،بيروت، 1412هـ، 1992م. - السيوطي ، جلال الدين، الدّرّ المنثور في التفسير بالمأثور، ، ط1 نحقيق: د.عبداله النركي وأخرين، مركز هجر للبحوث والدراسات العربيّة والإنساميّة،

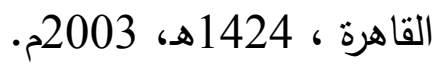

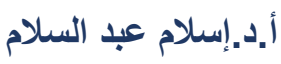

(تحولات المصادر في السياق القر آني دراسة دلالية..........) 
- سيبويه ، أبو بشر عمرو بن عثمان، الكتاب، تحقيق: عبد السّام هارون، ط3، مكتبة الخانجي ، القاهرة، 1408هـ، 1988م. - الثَّعراوي ، محمّد منولي ، تفسير الثَّعراوي، طبعة دار أخبار اليوم. - الطبّري ، محمّد بن جرير، تفسير الطبّري (جامع البيان عن تأوبـل آي القرآن): ،تحقيق د. عبد الله التركيّ وأخرين، هجر للطباعة والنّتر ،القاهرة، 1422هـ، 20012 - - د. طه الجندي، المصدر المؤوّل بحثُّ في الترّكيب والدلالـة، دار الثقافة

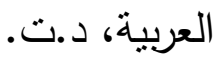

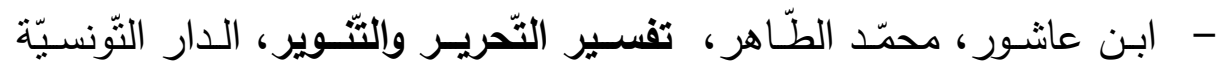

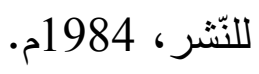
- د. عبد السّلام، إسلام محمد، اسم الفاعل بين التنوين والإضـافة في القرآن الكريم (دراسـة دلالية)، مجلّة كلّيّة دار العلوم- جامعة الفيوم، العدد "20"، -2008 - - د. عبد السّّلام، إسلام محمد، أثر السيّاق في بيان الأوجه الإعرابيّة "دراسـة تطبيقية على آي القرآن الكريم" ، مجلّة كليّة دار العلوم، جامعة القاهرة،"

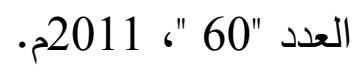

- د. عبد المطلب، محمّد، البلاغـة والأسلوب، ط1، مكبـة لبنان، لونجمـان ، 1994 - عضيمة ، محمّد عبـد الخـالق، دراســات لأسـلوب القـرآن الكـريم ، دار

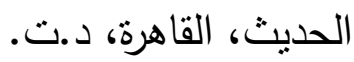


- ابن عطية الأندلسي،أبو محمد عبد الحق بن غالب،المحرر الوجيزفي تفسير الكتاب العزيز، تحقيق: عبد السـلام عبد الثـافي، ط1، دار الكتب العلمية،

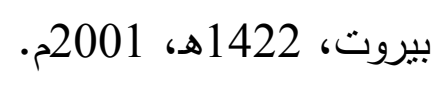

- ابن عقبل، عبد الله العقيلي المصري، شـرح ابـن عقيـل على ألفيّة ابـن مالك، تحقيق: ح. الفاخوري، دار الجيل بيروت، ط1، د.ت - الفرّاء، يحيـى بـن زكريـا ، معــــي القـرآن، عـالم الكتب، بيـروت، ط3، 1403هـ، 1983م

- الفراهيدي، الخليل بن أحمد، كتاب العين، تحقيق: د. مهدي المخزومي، د. إبراهيم السامرائي، سلسلة المعاجم والفهارس، د. ت. - القرطبيّ، أبو عبد الله محمد بن أحمد بن أبي بكر ، الجامع لأحكام القرآن،

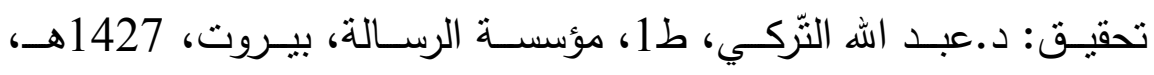
.2006 - قطب ، سيّّ، في ظـلال القرآن ، ط17، دار الثروق، القاهرة، 1410هـ، 1990

- ابن قيم الجوزية،محمد بن أبي بكر ، بـائع الفوائد،تحقيق: على بن محمّد العمران، مجمع الفقه الإسلاميّ ، جدة، د. ت. ت.

- ابن كثير،أبو الفداء إسماعيل بن عمر،تفسير القرآن العظيم، تحقيق: سامي بن محمّد السّّلامة ، ط2، دار طيبة، الرياض ، 1420هـ ، 1999م. - - لجنة من علماء الأزهر ،الوسيط في تفسير القرآن، مجمع البحوث الإسـلامية بالأزهر، ط1، 1400هـ، 1980م.

أ.د. إسلام عبد السلام

(تحولات المصادر في السياق القر آني دراسة دلالية..........) 
- المبرد، محمد بـن بزيد، المقتضسب،تحقبـق: محمد عبد الخـالق عضبيمة، المجلس الأعلى للشئون الإسلامية، القاهرة، 1415هـ، 1994م. - مسـلم النيسـابوري، الإمـام الحسافظ أبـو الحسبن مسـلم بـن الحجـاج، صـحيح مسـلم، تحقيق:أبـو قتيـة الفارايـابي،ط1، دار طيبـة، الريـاض، 1427هـ، .2006

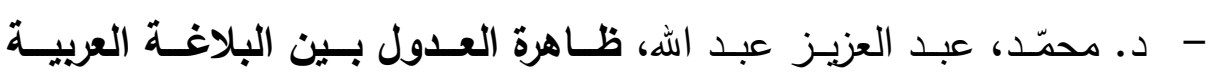
والأســلويية الحديثـة " رسـالة دكتوراه"، كلّبّة الآداب ، جامعـة الموصـل،

$$
\text { 1419هـ، 1990م }
$$

- ابـن منظور ،محمّد بـن مكرم ، لســان العـرب،ط1، دار صـادر، بيـروت، لبنان،2000م.

- د. هنداوي، د. عبد الحميد أحمـد يوسـف، الإعجـاز الصـرفي فـي القـرآن الكـريم" دراسـة نظريـة تطبيقيـة"، ط1، المكتبـة العصـرية للطباعـة والنشـر ،

$$
\text { بيروت ، 1422هـ، 2001م. }
$$

